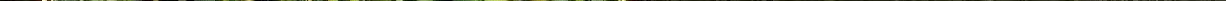









\section{Digitized by the Internet Archive}

in 2016 




\title{
MOTHS AND BUTTERFLIES
}

\author{
OF THE UNITED STATES
}




\title{
MOTHS AND BUTTERFLIES OF THE UNITED STATES
}

Eiast of the Rocky Mountains

\author{
BY S. F. DENTON
}

A Limited Edition of 500 Copies, of which this is

Copy No. 140 



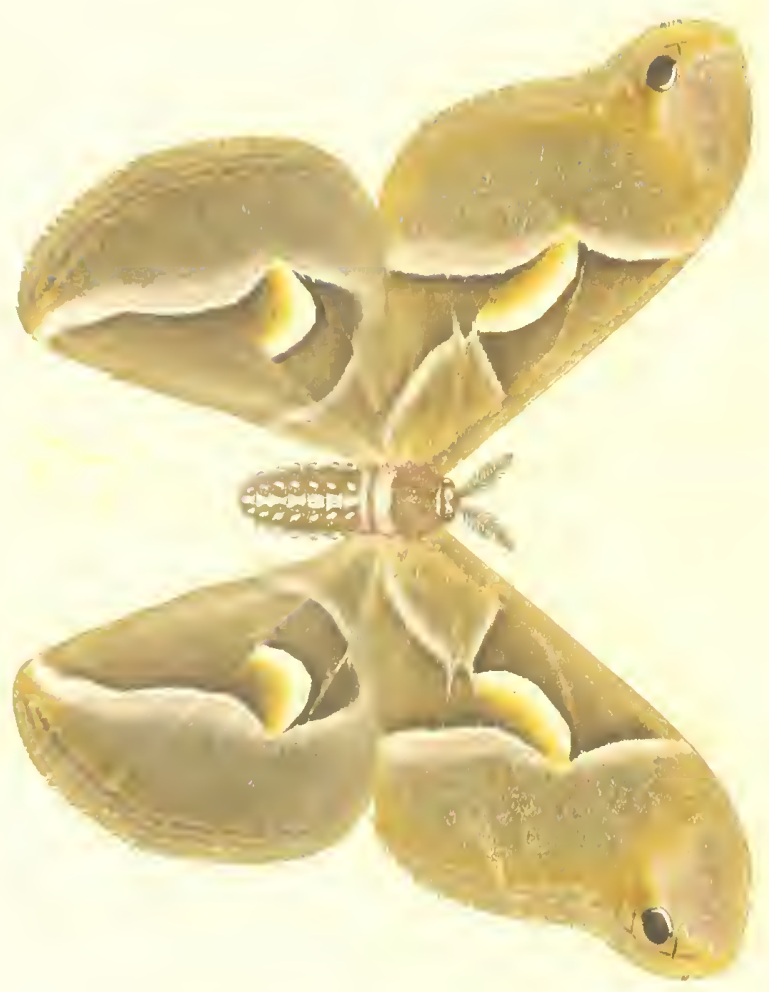

UPPER SIDE 


\section{As Nature Shows Them}

\section{MOTHS AND ButTERfles \\ OF THE \\ UNITED STATES}

\section{EAST OF THE ROCKY MOUNTAINS}

With over 400 Photographic Illustrations in the Text and Many Transfers of
Species from Life

BY SHERMAN F. DENTON

Part I. THE MOTHS

BOSTON :

BRADLEE WHIDDEN

1900 
Copyright, 1900,

$\mathrm{By}$

BradLeE WimDden 


\section{PREFACE.}

ScInntific works on butterflies are not rare in most libraries; hut to the enthusiast who loves these creatures for their beanty and rariety there is usually very little of interest in scientitic details.

It is the aim of the present work to represent our native butcerflies and moths not as dried and mutilated specimens in a cabinet, with pins stuck throngh them, nor as dissected fragments for scientific classification, but as one sees them in our woods and fields. fresh and lovely.

From the standpoint of the artist and the decorator. the sturly of the designs and color patterns on the wings of butterflies may be of raluable assistance. Such combinations of pleasing tints are rarely found in the handiworks of man. What better school could be found for the colorist than is within the reach of the humblest aspirant for fame as artist or decorator? Think of students copving the dingy works of the old masters year after year. when at their own doors the grandest combinations of colors that Nature can produce are passed by without a thought: We have close about us the hest that Nature is capable of producing, if we but use our eyes to see it.

The life histories of many of the lepidoptera are replete with interest, and the knowledge of not a few is essential to man's welfare. 'To the garlener or the florist the study of entomology is a necessity, and the recognition of his enemies and friends in the insect world is of first importance.

To those who have, or desire to have. a cabinet of specimens, this study will be found of never-failing interest, as one may pursue his researches through all seasons of the year. Improved methorls of mounting and keeping such specimens render their preservation and care a simple matter; and the collections made in one's childhood may be kept to delight one's oh age. The practical hints on collecting and rearing specimens, the result of many years' experience, will be appreciated by begimners and the new methods of illustration herein used will greatly help the student in identifying and naming his specimens. 
The colored plates, or Natnre Prints, used in the work, are direct transfers from the inserets themselves; that is to say, the scales of the wings of the insects ane transferred to the paper while the borlies are printed from engravinge and afterwart colored by hand. The making of such transfers is not original with me, lout it took a goed deal of experimenting to so perfect the process as to nrake the transfers. on account of their fidelity to detail and their turability. fit for use as illustrations in such a work. And what magnificent illustrations they are, conbodying all the heanty and perfection of the

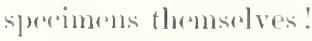

A. I lave had to make over fifty thousand of these transfers for the entire edition, not heing able to gat any one to help me who would do the work as I desired it done, and as more than half the specimens from which they were mate were collected by myself. I having male many trips to different parts of the country for their capture, some idea of the labor in connection with preparing the material for the pulblication may be obtained.

I will say, however, that there never was laborer more in love with his work, ol one whose labors took him among pleasanter scenes. In collecting such a lares number of specimens, many new facts in regard to the habits of these chaming creatures have been observed, and to write interestingly of their lives and to give a few axamplos of their mavellous leatuty has been the aim of the anthor.

SIIERMAN F. DENTON.

WHLLELLY, MASS, 18!9t. 


\title{
LIST OF TEXT ILLUSTRATIONS.
}

\author{
Pait I (Moths).
}

Butterfly scales

Antennxe.

Tongue of splinx .

Development of a Butterfly .

Caterpillar of Butterfly .

Development of the Motl

Detail of Net Rim.

The Net Completed

Poison Bux

Sliape for Collecting l'apers.

The Folding of Collecting Papers

Bundle of Inseets in their Enrelopes

Oven for Irying Insects

Relaxing-Box .

Insect Spread on Setting Block

Forceps for IIandling Insects

Various Forms of Plume Motlis

Pterophorus pentadactylus

Alucita hexalactyla

Tinea flavifrontella

Tinea granella

Hyponomeuta millepunctatella

Depressaria robiniella.

Various Forms of Leaf-Rollers

Lozotania cerasiovorana

Lozotania rosaceana

Intithesia pruniana

Carpocapsa pomonella.

Various Forms of Snout Moths

Galeria cereana

Crambus girandella

Larva of Geometrid Moths

Angerona crocataria

Brephos infans

Anisopteryx vernata

Anisopteryx autumnata

Zerene catenaria

Amphidasis cognataria

Rheumaptera lisstata 
Ilybernia tiliaria

Peotrophora diversilncelta

llamatopis grataria.

Geometra iridaria.

loutropela clematata

lindropia marginata

Therina sconinudaria

Endropia hypocheraria

Acidalia connceleata

Fintropela tramsversattal .

Frebus oderia .

Catocala relicta

Catocala concmuberis

Catocalat epione

Catocala fratercula

Catocilia patrata

Catocala rerogama

Catocalal mijuga

Catocalat subnata

P'ostphilat qualdrifilaris

1)listerial creentean.

Catoralit immurens.

Catocala flebilis

Caturala desperatat

Catocala palaeograma

Euclidia cuspuldea.

Rhodoploma floridit

Larva of 11 ollophila mipiancta

l'lusia simplex

l'lusia putuami

(xortyma nitela

Cucullia speyeri

lyrophila pyrmidoides

Mamestra picta

Larva of Mamestra picta

$\Lambda$ grotis tassellata .

$\Lambda$ grotis e nigram .

Agrotis normaniana

Agrotis herilis

$\Delta$ grotis venerabilis

Calocampa nupera.

C'atocala antinympha

Catocalar amica

Aputela lobelias

Eucirredia gampina

Parthenos nubilis

I'Insia ierea

Apatela americana

Gramatoplora trisignata

Larva of Gramataphora trisignata

Sylutes robinix. Female 
Xylutes robinia. Male

Sthenopis argentata

Clisiocampa americana .

Clisiocampa disstria

Tolype velleda

'Tolype laricis

Gastropacha americana .

Anisota senatoria .

Anisota rubicunda.

Chrysalis of Anisota rubicunda

Citheronia legalis. Male

Larva of lacles imperialis

Eacles imperialis. Male and female moth .

saturnia io. Female

Larva of Satnrnia io

Chrysalis and coconn of Saturnia io

Saturnia maia. Male

Larva of Attacus cecropia

Section of cocoun of Attacus cecropia.

Swamp and upland forms of cocoons of Attacus cecropia

Larva of Attacus promethia.

Cocoon of Attacus prometlia

Attacus angulifera. Male and female motl

Larva of Telea polyphemus.

Cocoon of Telea polyphemus

Actias luna. Male

Porthesia clnysorrhoea.

Cerura borealis

Larva of Cerura borealis

Larva of Elema albifrons

Edema albifroms

Colodasys micornis

Coelodasys biguttata

Larva of Colodasys

Nerice bidentata

Larva of Cdemasia concinna

Pheosia rimosa

Apatelodes torrefacta

Larva of Datana

Datana ministra

Limacodes scapha .

Limacodes quelceta

Parasa fraterna

Lagoa crispata

Case of the Lvergreen Bag Worm

Halisidota carra

IIalisidota tessellata

Larva of Orgyia leucostigma

Leucaretia acriea.

Phragmatohia rubricosa

Larva of P'yrrlaretia isabella 
l'virhametial isabulla

(")e(o) and pupla of an Aretian

Aretiat mais

Arrtia arge

Aretial phisleriatat

Aretia virgo.

I arval of cycolia exed

('allimenphis lecontei

llypoprepria miniata

C't'muschal virginica

lycomorplat pholus

Eutruas grata

Alypial octomacnlata

l'sycelomorphar cpinemis

Molittia enembitar.

Aigerial exitiosa. Male and lemale

Digeria tipuliforme

Tigerial pyri

latrva of Sphinx IIotly

I'upar of Splinex Moths.

llematris thyshe

llemaris diftinis.

Sreilephilal chamanerii

Woilephilal lineatal .

Everyx myron

l'nua of liveryx myrom.

latral of liveryx myron

leveryx chatribs

l'hilampelus pamtorus.

larva of l'hilampelus pandorus

l'hilaupelus achemen .

Marerosia quinduemaenlatus

Larva of Macrosila quinquenaculatus.

Macrosila carolina.

Jatrva of Ceratomia quadricornis

Ceratomia quadricornis.

Datremuli undulesa.

bolla hy laxus.

Siphinx gordins

Splinx elersis

Sphinx drupiferarm

Chlocrocimula tersil

Thyreus abbotii

Ampliom nessum.

Larva of Sincrintluw.

Sinerintlus geminatus.

Sincrintlus excacatus. Male

Surerintlus myops.

l'riptonon modesta 


\section{LIST OF COLORED PLATES.}

TIANSFERS FROM LIFE.

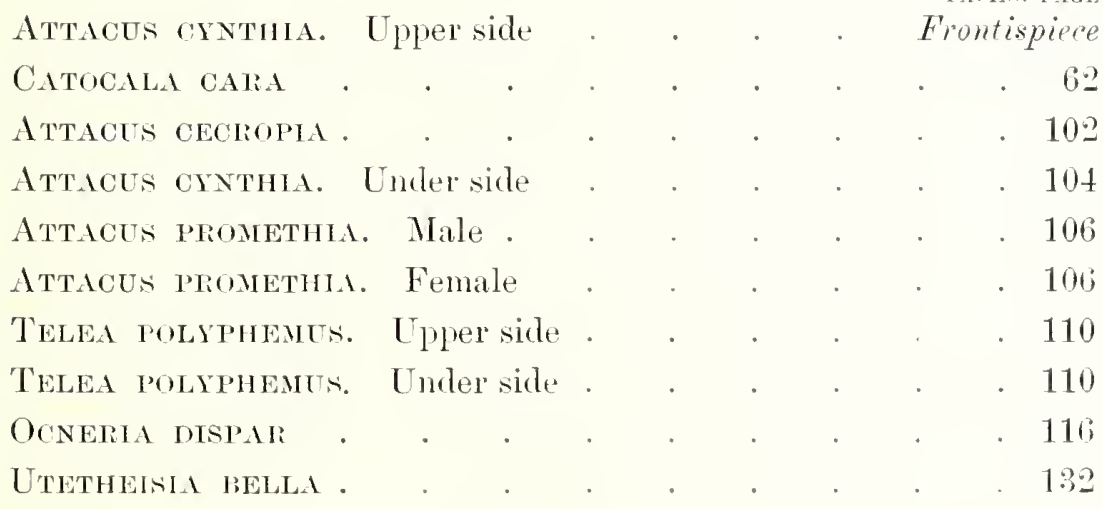





\section{CON'TEN'TS.}

The Life History

Implements for Collecting . . . . . . . . . 12

Preparations for a Cabinet . . . . . . . . . 19

IIow to make a Collection . . . . . . . . . 27

Collecting Moths . . . . . . . . 32

Classification . . . . . . . . . . 41

Heterocera. The Moths . . . . . . . . . 42

Micro Lepidoptera . . . . . . . . . . 43

Pterophorida . . . . . . . . . . . 43

Tineille . . . . . . . . . . 41

Tortricille . . . . . . . . . . 4t

Pyralide. . . . . . . . . . . to

Geometridie . . . . . . . . . . . 49

Noctuida . . . . . . . . . . . . 57

Bombycide. . . . . . . . . . . 8. 82

Kygrenida . . . . . . . . . . . . 184

Sphingida . . . . . . . . . . . 189 



\section{HETEROCERA}

THE MOTIS 


\section{Lepidoptera; or : Fcale=winged Ilnsects.}

\section{THE LIFE HISTORY.}

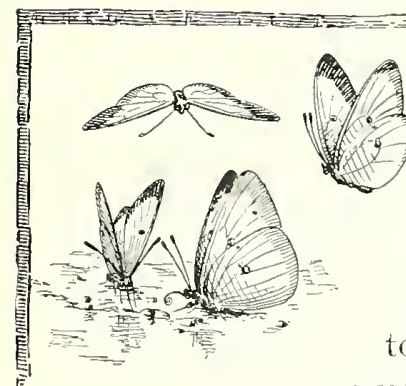

THE name Lepidoptera was first applied by the liaturalist Iinmaeus to the order of insects known as butterflies and moths.

The dust which covers the wings and bodies of these insects, when placed under a microscope of low power, is seen to he composed of minute scales. These vary in form from those elongated into lairs to flat wide plates not unlike in appearance the scales of fishes. The variety in shape and color of the scales of different species of Lepidoptera is amazing, and a number sprinkled on a nicroscopic slide will frequently display all the glitter and iridescence of a casket of precious jewels. To these scales the beauty of coloring of this order of insects is entirely due; for when they are removed, the

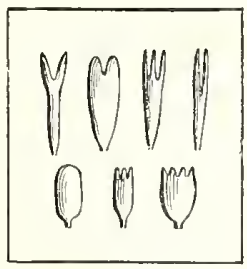

Butterfly Scales.

wings are seen to be composed of veins or ribs, with thin transparent nembranes extending between them. Many of the scales are striated or corrugated and decompose the light in such a way as to give to on eyes those combinations of colors so pleasing to behold. 'They are 


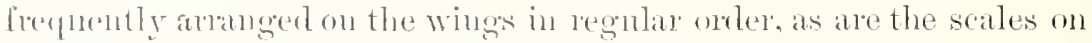
noptiles or fishes, and when removed leave a slight sear on the menhathe wheles they were attacherl.

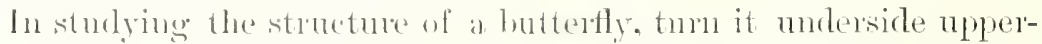
nost. It will then be seen to he comprosed of three distinct parts:

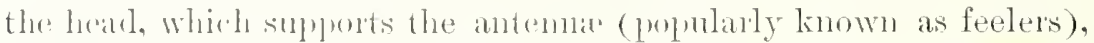
the ores. whel the month parts: the thomx, to which are attached two pains of wings and theec pairs of logs; and the abdomen.

'The eyes of butterdies and mothis are componud, and the facets vary in different sprecies from severat lumbled to many thousand. 'The vision of sone of the higher hnterflies is exeedlingly aente, as one will often have reason to note when cantionsly endeavoring to aphoach some coveter prize near enongle to nse the net. Many moths, on the contray, seem to be simply able to distinguish letweren light amd diuliness, and are aplatrently more often guided by the sense of sumell than of sight.

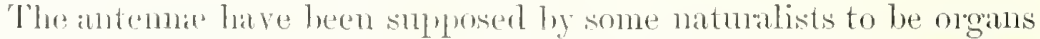
of sunell. and there is certainly good foumdation for this supposition. 'They vary in shape from harik-like and feather-like in many of the mothe to rods with ehulshalued ends in most of the butterflies.

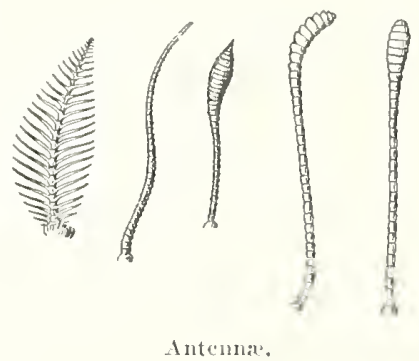

liy the antenna the heginnel may most easily distingnish between lutterflies and noth.s. The antemne of luttedlies are nearly always hlunt or knobled at the ends, while the same organs in moths are genceally pointed.

The mouth parts of the lepiloptera are constracted for sucking the sweets from flowers of the juices from other sulstinces : and whike some of the moth lave no way of taking nonlishment in their prefort state, most of the species of this order are provided with a 
long tongue which, when not in use, is coiled into a close spiral between the palpi. 'This reaches its greatest derelopment in some

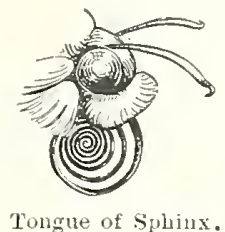

of the sphinx moths, enabling them while on the wing to extract the nectar from the deepest flowers.

While most of the lepidoptera lave six well-developerd legs, a group of butterflies, the $N$ ymplutidee, have the first pair so small and weak that they are probably of very little use to the insect. The legs are used almost wholly for elinging to sulstances while the insects are at rest, as very few of the lepirlontera walk or run to any extent.

The butterflies are day flyers, and in the hot sunny lours they sport through the woods and fields. The moths fly mostly by night, and are frequently more hairy and larger bodied than the butterflies, while their colors are usually softer and more blended.

The life history of one of the insects we are considering, from the egg to the fly, is most interesting. The perfect insect lays its eggs, by a wonderful faculty, which for want of a better word we call instinct, upon or near the speeies of plants which are to furnish the food for the future caterpillars.

These eggs, often very minute, are of rarions shapes and are ornamented in a variety of ways. Some are ollong; others almost perfect spheres; others agatin flattener above and below, while their ontlines are circular. With these shapes go smooth and sometimes lighly polished surfaces. Sone resemble low vases with turnerlover and fluted edges. while they are adomed with raised patterns on sharply cut grooves or circular pits, or in other exmples studded with nodules or even with spines. Others bear a general resemblance to a lady's work-basket in sline and reticulated ornamentation. Some lave a lid or cover, which is raised be the caterpillar when ahout to emerge from the shell. They rary too, in color as well as in shipe and ornamentation; some are white or of a pearly lustre, some blue or gray, while a large number are green, and a few brown 
or blark. An interesting collection may be mate of these eggs alone, and an entomologist can often tell from examining an egg the species of hutterfly to which it helongs.

When the linva emeroses so small and so unlike the mature insect, no one wonld guess what it was to be. It crawls to the tips of the tenter rommo leaves and makes its first meal. It soon begins to grow raprilly : and as it grows its skin becomes too small for its constantly incereing bulk, and a new skin begins to form under the old one, which after a short period of rest the eaterpillar easts off. This is ano: in the following manner: the insect finst spins upon the leaf or twig upon which it lests a mat of silk to which it can hold finmly with its claws and claspers. It ceases to cat for a period and lemains perfeedly quiet 11 mon the mat. It becomes so dull and sickly in appeanane that one might suppose it was about to die. At lengtl it hegins to twist its lead from side to side vigorously, and after a solies of (ontortions in which the forwarl segments swell and shink alternately, the skin splits down the middle of the back and the ront is further enlareged by the struggles of the inseet mitil it can draw its head and legs ont of the opening. when by seenring a

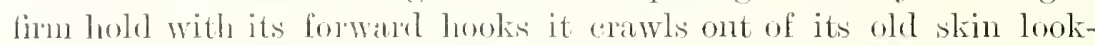
ing as lolight as a gold coin fresh from the mint. It is feeble and exhansterl fom its labou's, while its skin and even its heal and legs are soft and tender, and it now remains quict nutil the skin dries and foughers by exposule, when it is leacly once mole to attack with renewed anergy the tenter leatres of its food plant.

'Ilue cast-off skin sometimes retains the slape and eolors of the caterpillan to a smonising regree - a veritable ghost of the former insect. Some caterpillars devour their outgrown garments as a first moil alter emoh monlt; others luve them where they were cast; ancl one species arries in front of its beat on a tuft of hairs, during its coterpillar life, the cast-off shells of its head which were shed with arels dange of skin, thus kepping in sight a recold of its out grown eoverings from infancy. When the caterpillars are gregarious these castoff skins in groups representing each moult of the colony may frequently be seen on one plant. The moulting period is a critical time in the life of the larva, for it is not only helpless to resist the attacks of enemies but it may die fiom exlaustion in the at of sherlding its skin.

The larva eats lavenously (sometimes devouring twice its weight of food in twenty-four hours) after it resumes activity, with a 


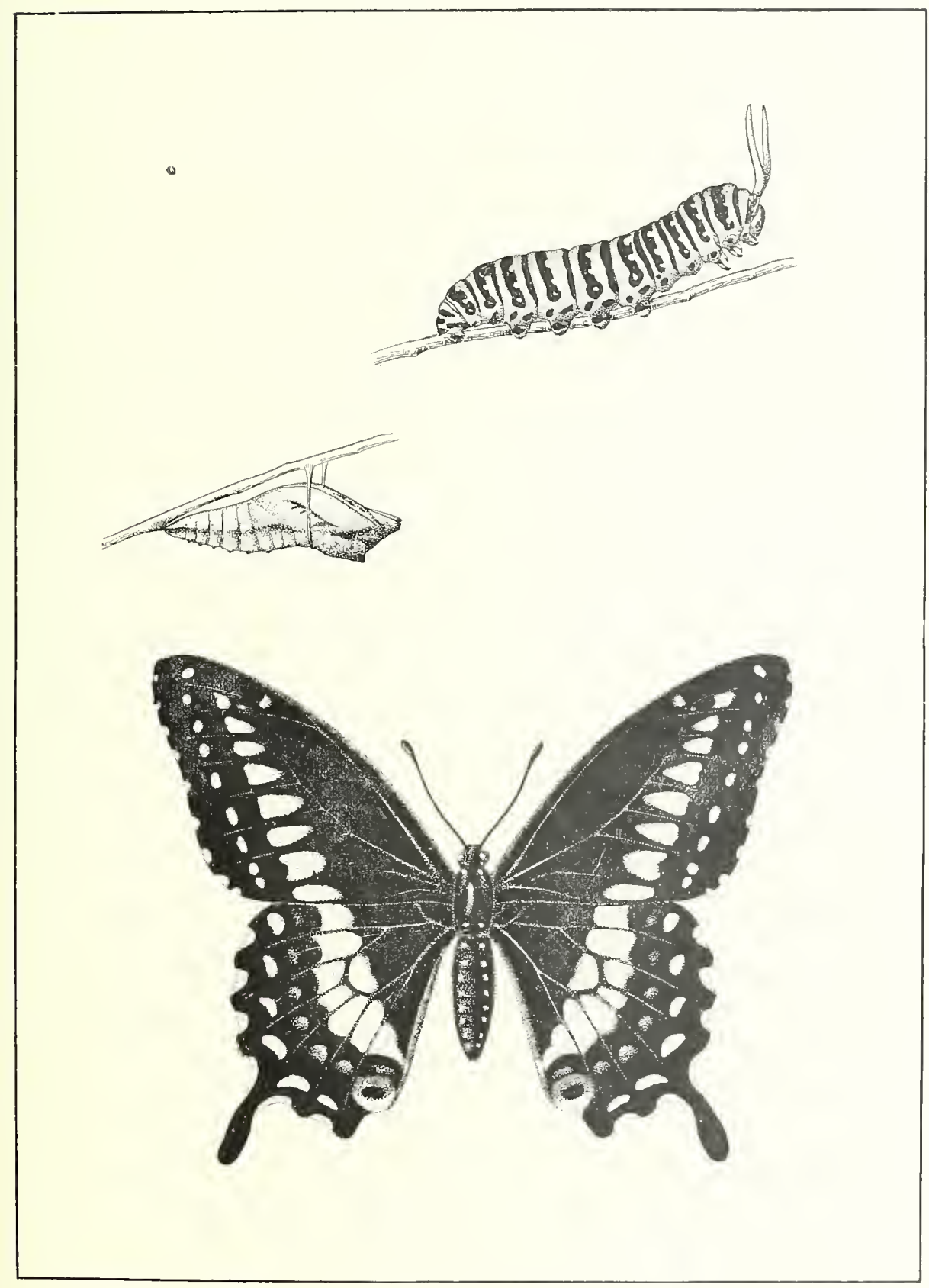

Development of a Butterfly. 

corresponding rajid growth in size. In consequence its new coat soon becomes too small, and the moulting process is repeated several (sometimes five or six) times, with colresponding changes in the size of the larva. In many instances there are marlied changes in the colors and the shape of the caterpillar after each moult. It length, in the course of sereral weeks, the insect arrives at its full growth. It now ceases to eat, and looks about for a suitalole place in which to pass its period of inactivity, known as the lupa or clnysalis state. And here, before he spins his cocom or clanges to a jupa, we will take a last good look at lim.

The larva of a lepidopterous insect is jointed or segmented into thirteen dirisions. First comes the liead. which is usually lard and holny: the eyes, twelve in number, are very small, and are placed near the mouth. They are simple eyes with very convex lenses, so that the range of vision must be very slort: in fact, so defieient is the sight of caterpillars one may conclude that they are guided more by the sense of feeling than by sight. Place a caterpillar on a trig and wateh it ascend, feeling its way and reaching out from side to side before every adrance movement. When it reaches the tor, it does not survey the scene below, but taking a firm hold with its last two or three pairs of claspers, it stretches its hody out to the utmost, swinging first one side and then the other, in orrter to feel if there is anytling beyond on which it can lay hold.

The jaws of a caterpillar move horizontally and are powerful instruments, capable in the larger species of hiting through the tough ribs of leaves as the insect reaches them while feeding. Crawling down the midrib of a leaf the caterpillat adrances towart the enge, and holding the leaf between one or more pain's of its holny front legs, it brings its jaws together on opyosite sides, eutting out a small piece with each bite, and continuing this down with regular order. it soon cuts out a large semicircular space, taking rihs anr all. I smaller caterpillar will simply eat away the soft parts of the leaf between the small ribs, leaving a skeleton: while the rerg minute leaf miner's burrow in the substance of the leaf between the uper and lowel skin.

The noise made by a large colony of larve while feeding has been compared to that male by a lieavy shower of rain on an attic roof; and the quantity of foor which they require is well-nigh aplualling to a novice who has started perhaps with seremal lumbled tiny ereatures which could all make a meal on a handful of leares. and 
finds that they need bushels of fresh food daily when nearly full grown. Of conmse, in a state of natue the large larval are usually wiclely scattered, so that their ravages are not so noticeable; but when feeding a large mumber hatched trom eggs one is liable to find he has an olephant on his hantls.

A little protuberance moler the month of the larva is the silkspinning organ. 'This is the external opening to the silk secreting glands, which comsist of two tubes or sacks, one on either side of the locky, containing the viscit fluid which, by exposure to the air, dries anel latedens into silk. This silk is used in a variety of ways by the different specios of caterpillars. Some colonies build nests for their mutual protection: others attach a thin threal to the leaves and hanches of the plants as they crawl over them, so that they are with diflicnlty shatien olf, for they merely let themselves down on their threats a short distance and then crawh up again when the danger is phist. Many speries spin cocoons as silky eoverings for themselves when they are abont to puldate: and a good many of the butterfly larve not only attiuh the posterion extremity of the abdomen to a silken carpet but anchor thenselves with a strong cable spun abont the berly and attached to the substance from which they are susprenderl.

If we exmmine a aterpillar, we shall notice that the first three

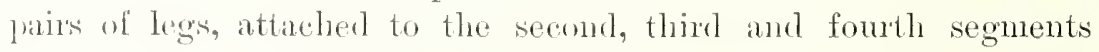

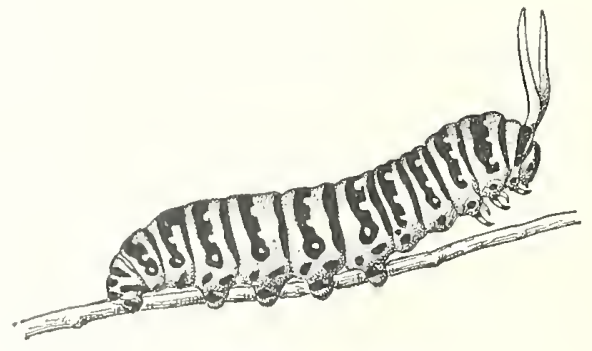

Caterpillar of Butterfly.

(calling the hear the first), are different from the fleshy legs or claspers. These finst six legis are hard and homy and provided with claws or hooks at the endis. 'They are the true legs and corresiond to the legs of the perfect fly. The usual number of claspers is five lairs, ind these are placed on the seventh, eighth, ninth, tenth and 
thireenth segments - the fifth, sixth, eleventh and twelfth segments having none. A number of catelpillars, howerer, have but four pairs of claspers (also called ablominal legs or prolegs), while a few have but two pairs, and these situaterl at the extremity of the body. The claspers are thick and fleshy, and may he extended or contracted, while their ends are surrounder with a number of minute hooks. These prolegs or claspers are absorbed into the abdomen of the insect during its transformation into a pupa.

In walking, a caterpillar advances by an undulating motion, extending and contracting its body. I few species (the geometricls) advance by bending the body up into a loop and then extending it to its full length. 'These are sometimes callerl inch-rorms or measureworms, from their mode of progression.

Insects breathe through spiracles or air-tubes in their sides: and the openings of these tubes are often plainly visible in caterpillars, especially in smooth ones. 'They are located on the segments, one on either side, and are often enclosed in a small circular or oral patch of eolor.

The variety of the shapes and colors of caterpillar's is well-nigh endless, and often most wonderful. they being adapted in many instances to so resemble the plants mon which they feed that their enemies are baffled in their search for them.

Some look and act as if they were renomous, while others are by their repulsive or even terrible appearance calculated to frigliten insect-devouring creatures. Some are smooth-slinned. some humped, or covered with bunches, tubercles, warts, fleshy filaments. lorms, spilies, spines, bristles, hairs or down, and sometimes a combination of several of these. A few sting like the nettle, while other's sher their sharp pointed hairs which work into the flesh if they are roughly handled. Some secrete strong. disagreeahle odors, while some are perfumed like a dandy at a ball. Their colors are scarcely less wonderful. Some bear large spots which look like great eyes watching from the leaves. Some are striped or banded, or sprinkterl with dots. 'They are of every imaginable color or shacle, but the majority are green, and so neaty resemble the leaves anong which they feed that it is difficult to see them. Some look as if made of bark and covered with lichens; others so chosely resemble twigs with their minute knots as to deceire even the expert.

But with all these subterfuges for protection, the binds. toads and ichnemmon flies find most of them out : thus, in spite of the comntless 
millions which, hatch from the egg's each season, their numbers are mostly kept within hounds.

But to resume our history of the life of the eaterpillar. As before mentioned, some speeies make for themsel ves cocoons; others burrow down into the suil or hirle among the fallen leaves at the roots of trees; while still other's have no covering, and suspend themselves by silken wehs in varions localities. In preparing for the pmpa state a thange takes place in the appentance of the caterpillar. Its colors fate: it shortens and thickens: and at length, after move-

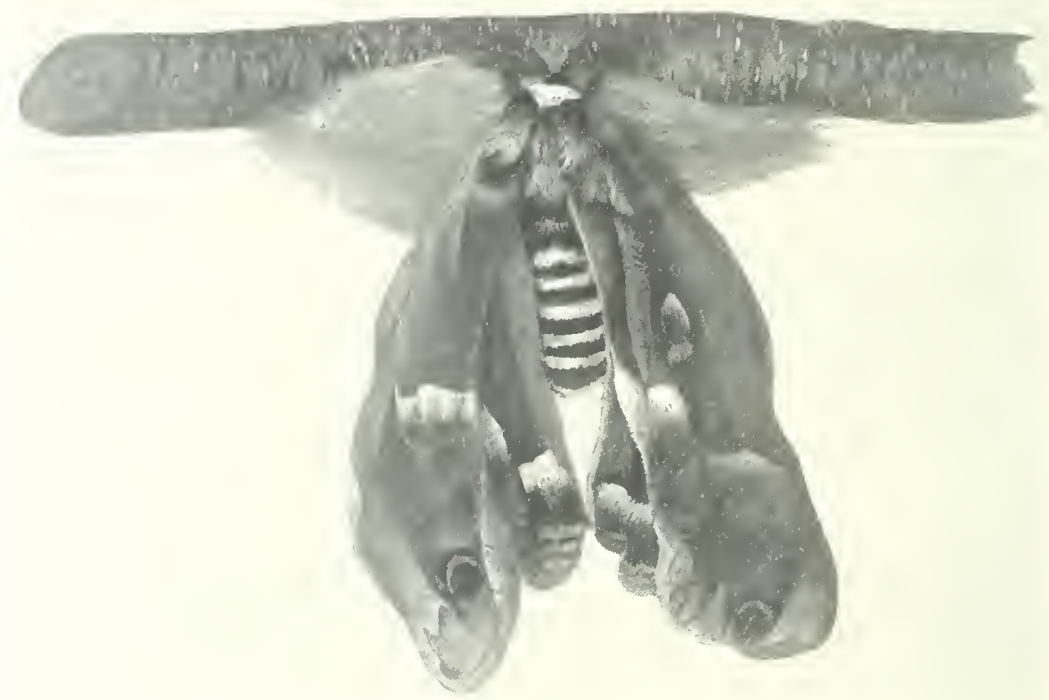

Development of the Mloth.

ments sinnilar to those which it uses in changing its skin in moulting, a ream opens in the baek, and the larval skin is worked lackwards and finally off.

It is now a pupa or chrysalis, looking neither like the caterpillar which it was nor the fly which it is to be. By close examination the lege, wings antemni, etc., may be elearly made out: but how comlackly they are placed together: Not a partiele of room is wasterl. It seens most marvellous that from this inactive, fossil-like creature, 
a butterfly full of life and beauty shall emerge. Beneath this hard and usually dull-colored exterior, what wonderful changes are taking place! Simple eyes give place to compound eyes; biting jaws change to a sucking tube, with its palpi; antenne spring from its head, wings from the sides of its body, and a delicate seale armor covers the whole. What tale from "The Arabian Nights" can equal marvels in the life history of a common butterfly? At length after weeks, in some cases months, of inactivity, through the shell of the elrrysalis may be dimly seen the color's of the developing insect. A slight split opens in the back of the shelly case, and as this widens and opens the butterfly slowly crawls out, and, after finding a suitable place, hangs almost motionless. The ereature is still very unlike the butterfly with which we are so familiar. Its body is soft and weak; its wings are no larger than one's finger-nail, and it looks wet and bedraggled. But watch it. Its wings begin to swell with the fluid which is pumped into them from its body. It appears to grow as we look, and in half an hour it is a glorious creature, a living jewel. Oh, how perfect and beautiful it is - not a mar on its velvety wings! We rarely see onc in a wild state so fresh and flawless. It is now at its hest. It has reached this grand climax after weeks of preparation, and we can but almire its wondrons beauty. With the emerging and developing of the perfect insect, its growth ceases, for a little butterfly never grows to be a big one. A part injured, a wing torn, is never mended; loosened scales are never replaced; and its life from now on sees it less bright and benutiful day after day. After depositing its eggs for the next generation it soon becomes a tattered, helpless creature, and falls an easy prey to one of its many enemies. 


\section{MPPLEMENTS FOR COLLECTING.}

\section{TIIE NET.}

Finst of all and most important of all is the net. The lightest, most servicalile, and in every way the best net that I know of is male with a rin of rattan. I'rocure a light piece of straight-grained jine, two feet long and one inch thick. Plane it down for a net hamble a little smaller at one end, and make a grove with a gouge, on either side of the smaller end, four inches long. Now, take a

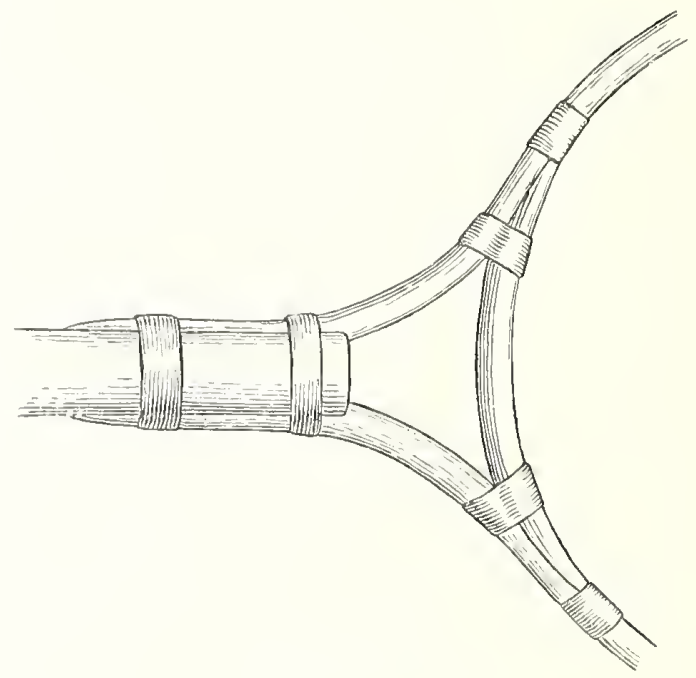

Ietail of Net Rim.

piece of rattan sixty-six inches long, rather thicker than a leadpencil, and fasten the ends to the handle with two bands of copper wire. This will make a net alout eightcen inches in diameter. By now taking a short piece of rattan, twenty inches long, making a long level at loth ends, grooving them out a little and wiring it to the rattan hooj, as shown in the following figure, you have a splendid rim for a net, and one that will last for years. In order to be sure 
that the hoop will be symmetrical after it is completed. it is a good plin to first fasten the small piece of rattan on with twine, and when it is satisfactory in shape, wire the whole together in a substantial manner. The rattan will bend better if soaked in hot water for an hour. A coat of paint or shellac over the handle and the bands of wire is likely to make the whole more durable.

To make the net, about two yards of mosquito netting. one yard wide, are necessary. Sew the netting on the rim with strong thread (carpet thread will answer), button-hole stitch, selvage next the rim, and when round, cut off the surplus and let the net hang down. The net should be made rounded, not pointed, at the

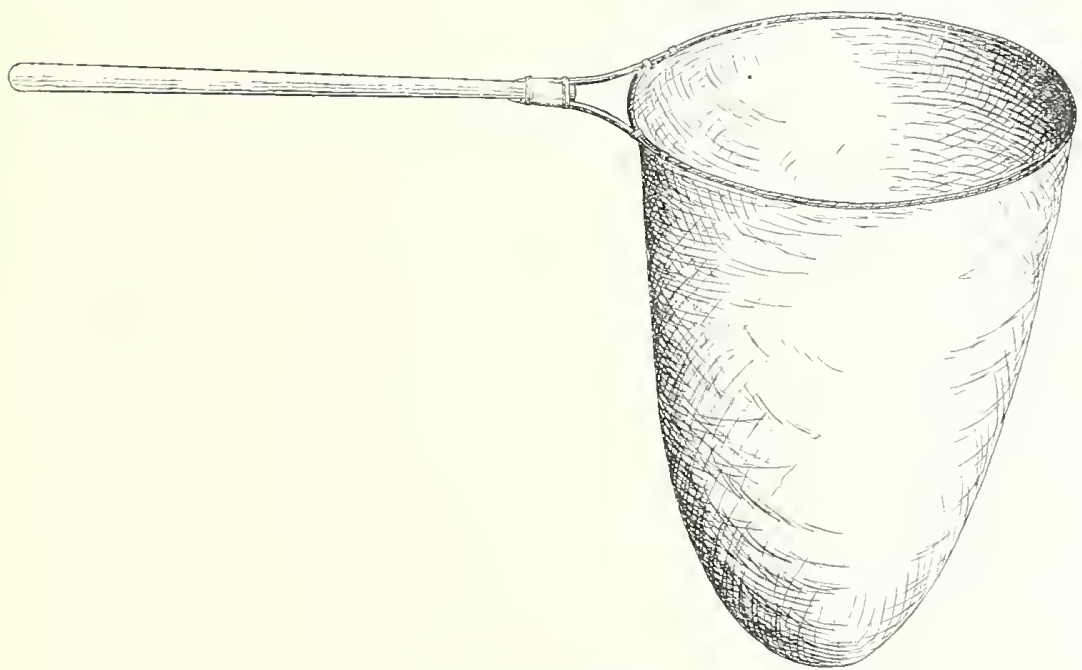

The Net Completed.

bottom; and, in order to accomplish this nicely, pin the sides of the netting together at intervals of two or three inches, ent off the corners with scissors, and sew together with an over and over stitch. The finished net should look like the annexed figure. The netting used should be soft and fine and of some inconspicuous color, such as brown or green. New netting generally contains some starch which renders it stiff, but soaking in hot water for a few minutes after the net is made will obviate this difficulty.

The netting will have to be renewed once or twice in a season if much collecting is done. If rattan is not easily jrocurable, one may 
nse stout iron wire such as telegraph wire, but it makes the net leavion and less flexible. A straight piece of willow, as large as one 's little finger, will answer for a rim when nothing else can be ohtaned. Some may find that a net smaller in diameter and with a longer handle will answer their purpose better: but it is diffieult to manipulate a net with one hand if the landle is longer, and the larger the net one ean swing the more likely lie is to eapture the large and rapicl flying insects which may eome his way.

Where insects fly very high, as they sometimes do, a net will have to be fistened to the end of a pole. $A$ jointed bamboo fishpole is a very goorl thing to use in this case, as the short liandle of the net may be fitted into the brass ferule of the rod at the seeond joint. Bat it will rarely be necessary to use a net of this deseription as most of our native butterflies may be easily taken with a shorthandled net.

\section{COLLECTING BOX OR JAR.}

A thin glass tumbler, with a tight-fitting cork stopper, will answer for killing small specimens and an occasional large one; but it is almost too small for one who intends to do a large amount of collecting. The tumbler is prepared as follows: Put into it one

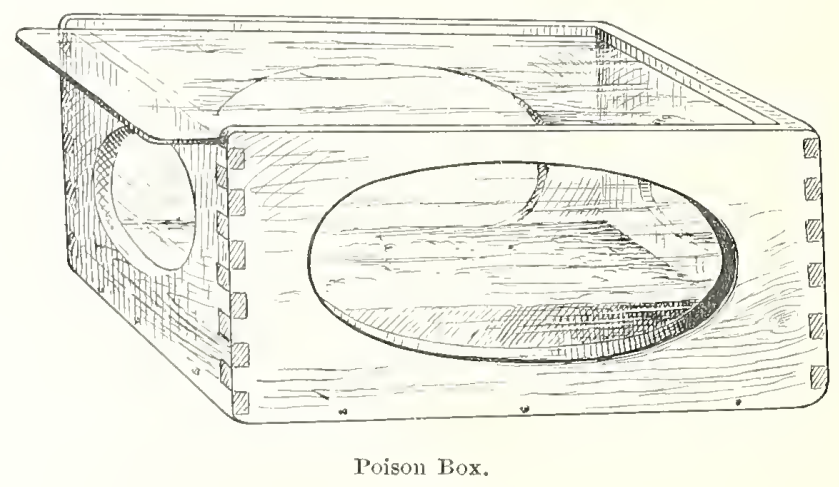

ounce of cyanide of potassium broken into fragments and eover with an inch of sawdust well pressed down. Mix a small quantity of plaster-of-l'aris and water to the consistency of rich cream and pour over the sawdust to the depth of half an inch. When the plaster hardens the "bottle" is reatly for use, lilling in a few moments, 
without injury, all insects placed in it. Great care should be used in handling the cyanide. Do not breathe the fumes of it as they are deally poison.

A more convenient and more useful article for lilling insects can be made in the following manner: Purchase at the drug store a small box with a sliding eover and dovetailed comers, six inches long, four inches wide and three inches deep. It may be difficult to get a box as shallow as this, but if the other dimensions are right. it may be cut down to the right height. This box should be taken to a glazier, and have him fit into it one piece of glass for a sliding cover and five pieces for bottom and sides. These latter pieces should be fastened on with shellac, and thin glass should be used to make the box as light as possible. When the shellac is dry, put in the cyanide as with the tumbler. This box will hold a large number of insects with papers between them, and will be found very useful when one is doing much collecting. Occasionally the cranide becomes so dry in the collecting box or bottle that it fails to lill the insects quickly. The addition of a few drops of water will generally restore it to full strengtl.

A small leather satchel suspended by a strap from the shonlder is a first-class addition to the collector's outfit. Into it may be put the captured insects in their envelopes or collecting parers, with needles and thread for mending the net or the clothing, inseret forceps. etc. A small light box with straps attached may be used in place of the satchel.

Collecting papers or envelopes are made thus: Take smooth,

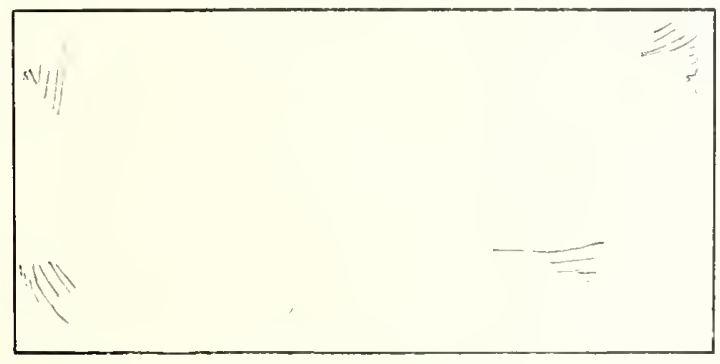

Shape for Collecting Papers.

strong paper (newspapers will answer if nothing better can be procured) and cut out an oblong piece as shown in the cut. Fold the 
encls across at right angles to each other: after which fold one of the ends over again, put the insect in lhead downward, being care-
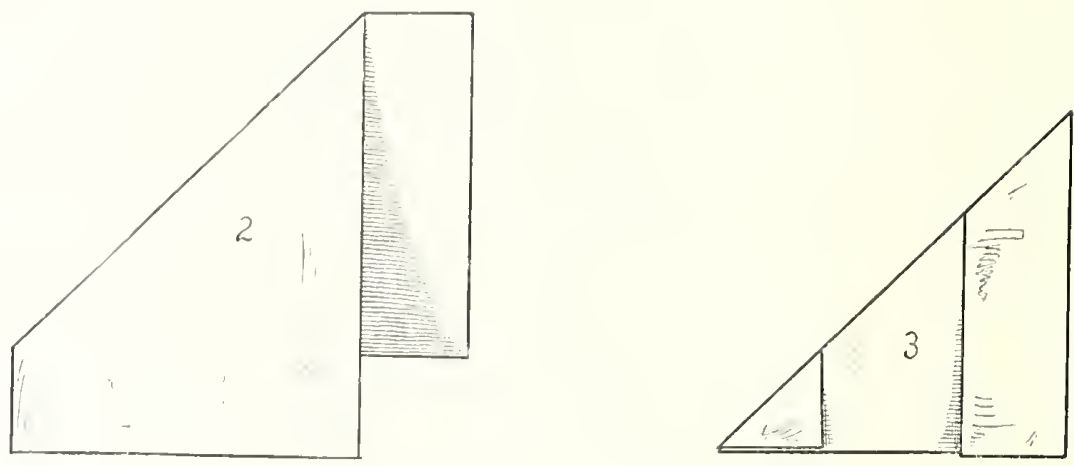

The liolding of collecting Papers.

ful that its wings be llat; fold the other end over, and the envelope is finisherl. Some collectors fasten one ent of the proper down with a little gum ol paste; hut the dried insect is not so easily taken out of such a laper. One collector whom I know uses compon envelopes for his butterflies. 'Tley are very cheap and convenient to handle, being all one size.

Insects in their papers should be left exposen to the air for a couple of days to partly dry; then they may be tied up in bundles,

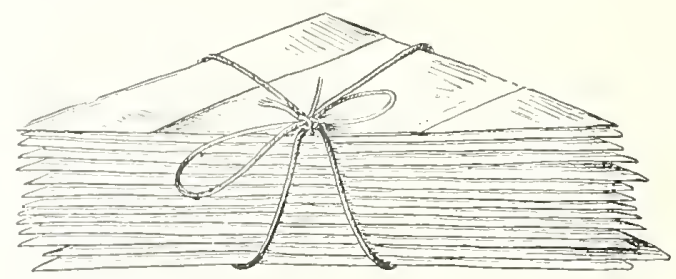

liuntle of Insects in their Envelopes.

and are rearly to store away in boxes or to be sent hy mail or express to their destination. 


\section{TO IORY INSECTS.}

In very wet weather insects may have to be dried artificially, to insure them against mildew. I good article for this purpose is a light tin or sheet-iron oven with detachable legs so made as to be set

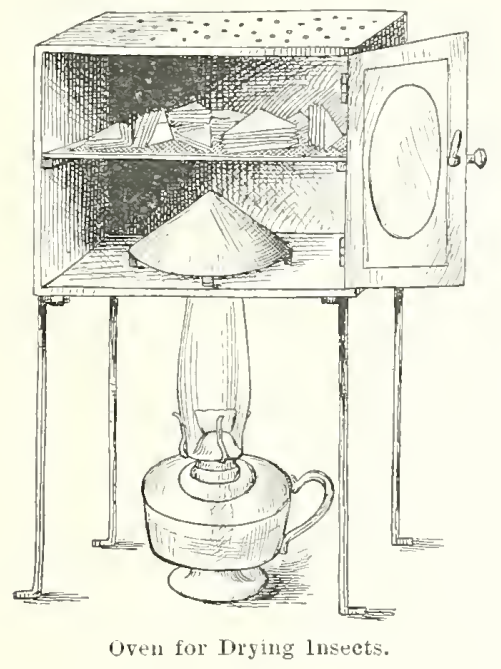

over a lamp. In this the insects are placed in their palpers. 'This is very useful in tropical countries where specimens may be taken at the rate of several hundred a day; but ordinarily one can use the kitchen oven for drying his speeimens in wet weather. Lay them lonsely on the oven shelf, with the door slightly open and they will dry nicely in an hour or two. Some very large-bodierl insects talke a good while to dry: and if a slit is made in the moler side of the abdomen with a sharp knife, the contents taken out and the sprace carefully fillerl with cotton gently crowded in, the body will look better when thy.

The bodies of many of the latge moths, especially the males of the silk-spinning species, are filled with a natural oil which is liable to gratually ooze ont and spread over the entire insect, ruining its appearance and perhaps causing the poor collector many a sigh orer his lost treasture. This may be remedied by cleaning out the aludomen of all such insects and stuffing with cotton. Another method 
which I have used with success is to snip off the abdomen of such an insert, cut it open on the under sirle, remove the contents and soak it in gasolene for twenty-four hous, after which it ean be stulferl and replaced in its former position with shellace This process, of course. does away with all liability of the inseet becoming sreasy.

Tor restore the beanty of greasy specimens, place them in gasolene in at shallow, coveren pan, for twenty-four hours or longer, when they will come out bright and "han. Downy or hairy specinens may need a little howing to restore their fluffy appeanance.

'The funnes of bisulphirle of carbon will kill insect pests whieh nualy have found their way among umounted speeinens. Pour an onnce or two into a dish placed in the eabinet and elose it up tight for forty-eight hours. Care shouln be exereised in its use, as it is very volatile and explosive. 


\section{PREPARATIONS FOR A CABINET.}

There are several ways to prepare lepidopterous insects for the cabinet. I need mention but two: one by the ordinary method of spreading the wings and with a pin thrust through the thorax, well known and used by most collectors the world over since man began to collect and preserve the beautiful objects of nature; and the other by a new and improved method invented by the author in 1894 .

After having aceumulated a beautiful collection of butterflies and moths from different parts of the world, only to see it finally destroyed in spite of all the eare I had bestowed upon it, and knowing my experience had been that of hundreds of other persons, the necessity of some means by which specimens might be kept safe from the many dangers which threaten them forced itself upon me. Is the result of a good deal of thought and many experiments. I invented a simple. light, strong, glass-covererl tablet which not only renders the destruction of the specimens impossible, but puts them in a shape at once more beautiful, and infinitely neater, than was possible by the antiquated method of impaling them on pins - a prey to insects and a refuge for dust - and liable to be broken even by a careless breath.

Some of the advantages of my invention over the old method of pinning insects are these:

They are protected against breakage, dust and museum pests, and specimens once so put up are good for humdreds of years.

A collection thus mounted needs no eare whatever, neither is it necessary to lave tight boxes or cabinets; and one may leave his collection indefinitely without the least danger.

There is no odor from the specimens, neither is it necessary to fumigate the cabinet at all, and the vile smells camsed by the use of miphthaline and bisulphide of carbon are entirely done away with.

There are no pins to obstruet a view of the specimens, or to make them appear as if impated alive.

There is no danger in showing the collection to any one, and the most valuable specimens may be handed around for a close inspection of their beauties without the least danger of breakage. 
1 collection of this hind oc(upies hnt half the space of a collection nomnted on pins, as the dlawers of the cabinet neal be but one inch dece inside.

I astly, the wings of specinens momed in this way lie perfectly flat, as the glass reste dineetly on them, and they therefore cammot lop down or wille 11) as plinned insects are liable to do.

Jany will besmberised to see how lovely are some of our most anmmon things momnter by this new method, making each specimen a piotilin:

The tablets are malde of many sizes, to aceommodate every valiety of spresinen. 'They are flat on the top, with a bouly eavity of the size and shape to lit the horly of the insect; are white with a olss-like polisle on the face : are holkow at the back, in order to be as lishte as possible, and this hollow is covered with earl-hoard when the insects are monnted.

Is my own method is in every way smperion to the other. and is alcarly being alopted by the mesemons not only of this eountry but of the world, I shall devote the nost of this chapter to a detailed description of how hest to gut up a collection as it should be to remain indefinitely, and to show to the hest advantage. I an aware that I shall encounter-in fard I have alrearly encountered - the oplusition of many of those collectors who have spent years in putting np their collections by the old methors. It is not reasonable to smplose that entomologists will welcome with open arms an invention whide makes the collections of a lifetime look poor and out of date: lnt why, I ask, should not impovenents be marle in monnting hutterflies as well as in making shoes or in printing newspapers?

This is an age of invention. Everything is being impored upon where the ingenuity of man ean suggest implovenent, and we are no lomger satisfied with the moss-grown mothods of our gramelfathers. Go into almost any of our musemm or latural history looms, and look at the collections of hutterflies. Dir one ever see anywhere alse such a miserable display? Wings torn and worn, hodies devonmed by musem posts, and the whole so dusty that one an scancoly identily the species. Why, any able-bodied collector can make and put 11] in one season at very small expense a collection that will gut to slane any of the exhibition eollections in the musemus of the comntry. Collections of inseets an be made surpassingly heantiful and an ornament to the finest palace that man ean build. It is no discredit to a musenm to have the best. It is a mis- 
take to suppose that a collection need be slovenly in order to be scientifie. Science should be made attractive, and the beaty of which Nature is so lavish should not all be driven from on museums. Olal curiosity shops for the storuge of oljects of natural history should give place to magnificent buildings devoted to the display of the rarest and most heautiful which Nature produces. I will make no further excuse, therefore, for introducing my invention to the reader's notice, for, ontside of my personal interest in the matter, it is the only practical way known to me of mounting a collection of lepidoptenous insects.

Let us suppose, then, that the eollector has been out with the net and has brought in an assortment of butterflies for the beginning of a collection. These may be spread either when fresh, or, which is simpler, may be placed in collecting papers and allowerl to dry, and when a number are procured, softened in the relaxing-box and then spreal. This latter method is preferahle in many ways, the most important heing that the specimens having once been dried will dry again very quickly, twenty-four hours usually heing suffieient to render them rigid, while if the insects are spreal in a fresh state they may require from fom days to two weeks to dry thomomglily.

\section{TIIE REIAXING-IBOX.}

To make one, use a tight box, one foot square and five inches deep, with a hinged cover; paint it inside and out with three roats of house paint, and when thoronghly dry jut into it two inches of wet sawdust pressed down hat. Malie a light woolen frame to fit the inside of the box. stretel netting over it and secure it with two or three brads an incle above the sawdust. When this is all reacly place the dried insects on the net, and in twenty-four loms they will be soft enough to sprean withont breaking. The success of this methor depends on having a tight box. The net on the flame does not allow the insects to come in direet contact with the wet sawdust, but they absob enough moisture to render them pliable and are not liable to heeome too wet. Silk veiling makes an excellent article to use on the frame in place of the net, as it is soft and fine. Water should be added to the samdust whenever it becomes too diy. I small quantity of powlered alum put into the water will prevent the sawdust fiom becoming mouldy. 
I much simpler way, although to my thinking not so wafe to use with vahable specimens, is to have a plain woolen box filled with wet samblot in which deep grooves ate made and the butterflies plared buty down in their papers in these grooves. One neerls to be aidoful not to have the sawhost too wet in this case as the insects are liahlo to alsork too much water, which may injure their appearance.

dlet the inserts have remained in the relaxing-hox until pliable (the following method may also be nsed for fresh specimens), they slomld be spreat mulerside uppermost on smontl pine blocks; these

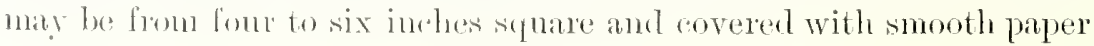

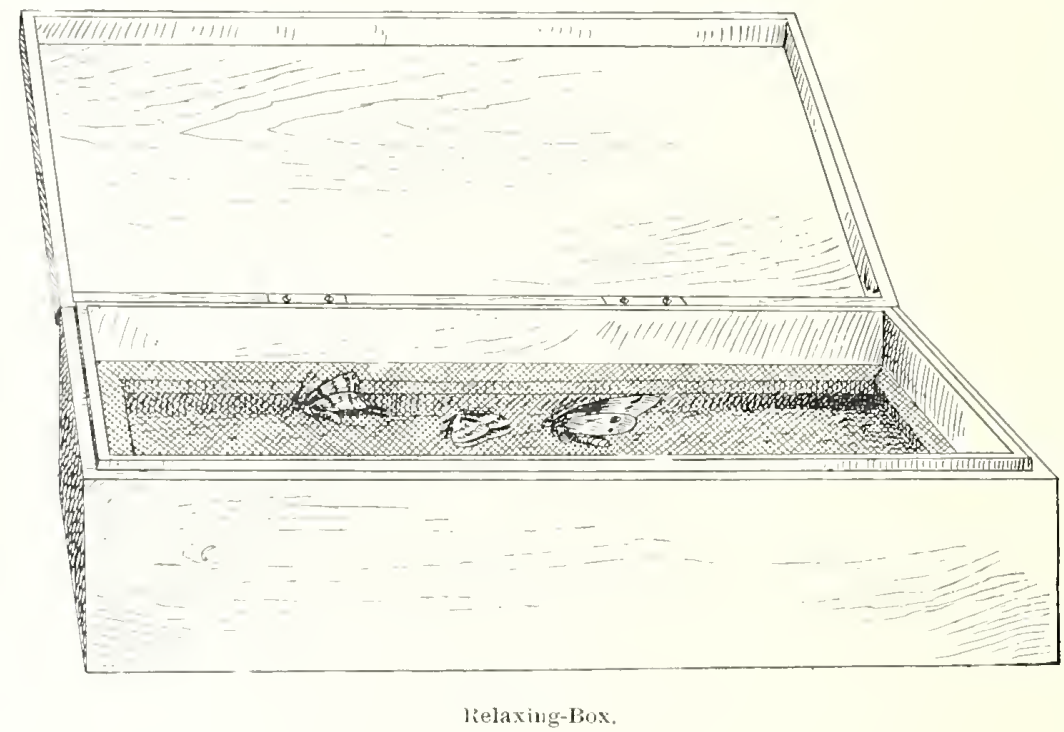

pasterl to the fare. Pin the insect to be spread though the thoma (stout insoct pins will he fomml hest for this purpose) ou the bloek

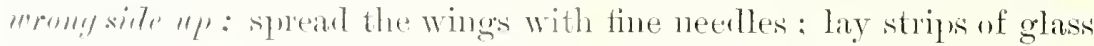
on then : secure the legrs and antenne in place with pius: and allow the sperinen to dry, after which it will be found very flat and in the light andition for monting. Inserts may be kept in this state in a tight hox until the collector is realy to mount them in the tablets.

1 gonl many insects, specially hutterflies, show a manked rifferruce between the mpres and under side of the wings. When it is desired to show the muler side, the insect should be spreat on the 
bloek riglet side up and the glass strips placed on the wings not far from their tips so as not to bend the wings too much. In spreading a fresh insect the pin through the thorax must be removed at the time of spreading, otherwise it will become so firmly attached that the specimen may be broken in removing it. With an insect which has once been dried this precaution is not necessary as the pin may be removed at any time.

A smooth paper or palette linife will he foumd useful for opening the wings of the insects to be spreat. Take the sprecimen in the left hand between the thumb and finger, and after inserting the linife between the wings bent them down on each side. If all the insects

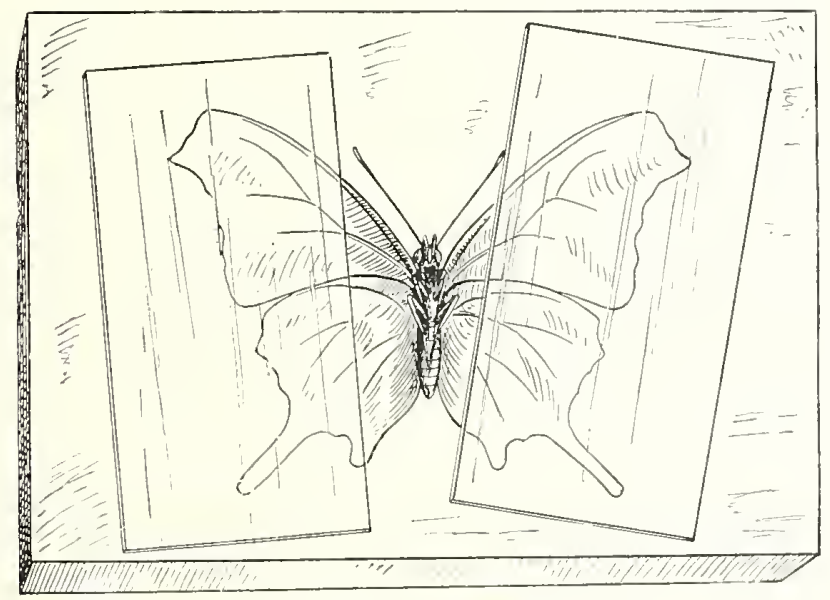

Insect Spread on Setting Block.

in a collection are spreat so that the lower margins of the upper wings are at right angles to an imaginary line diawn lengthwise through the centre of the body the whole will look miform and the boanty of the individual insects will be shown to the best alvintage. The setting needles may be made more convenient to nse if the emls are pushed into small wooden handles, mateh stubs for instance. If the needles are too long, as is apt to be the case. lreak them in two and use the points only. For menting hroken insects and replaring detached antemne and legs, use white shellace. The appearance of a specimen whose wings are slightly injured may be very much 
improved by lastening on the back with shellate a piece of another henterelly which matehes it in rolor.

For hambling inserts, nse smooth hroml-tipled forceps. If these (annot be purehased at a store where naturalists' supplies are kept,

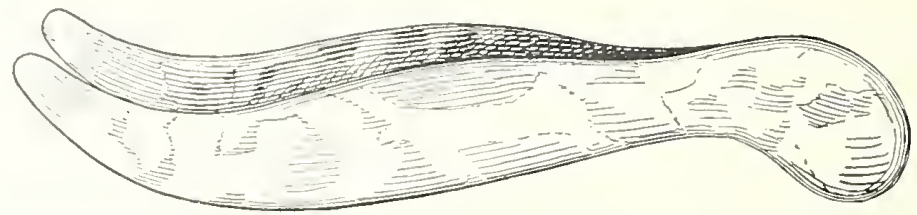

Foreeps for llandling Inserets.

a pair may be mate hy an expert ont of lard rubler or tortoise-shell. I have known a pail of tin eandy tomgs to answer for forceps after the tips ware made that and smooth.

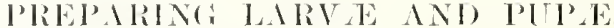

Collections where lanve and pupe are adcled are enhanced twofold in their value from the standpoint of the naturalist. The weird and valued forms with the remarkable coloring of some of the species makes then excertingly interesting when taken in comneetion with the fully ateveloperl inscet. When it is remembered that the aretive life of a hutterfly is but a very few disys at the most, and that hy far the greatel part of its existence is gassed in the lalval state, the state when it is directly injurions to man is interests. one am realily apereciate the inmortance of stuclying the inseets at this stange. Ialdar are not easily prephed to look well in the cabinet, and to make them look at all matural requires painstaking labor.

(He method, which has been used with consinemale success, is to indlate and bry the skin of the larva after the contents have heen sifuerast ont through the anal opening. This is ane by first killing the laver in the poison jas, then laying it on soft parper or cloth and, lexginning at the heanl, rolling it gently towarl the posterior end, muler a romed lead-pencil womml with soft canton-flanmel or blotting-

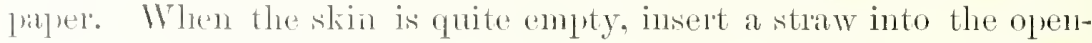
ing and gently inflate the skin, at the same time turning it round over 
a lighted lamp. A small spring of steel fistened to the end of the straw in such a way that it may prevent the slipping of the latrat skin as it is inflated will prove useful, am a little slest-iron oven to slip over the lamp, having small openings aljove and helow, will prevent the buning of the specimens as they hry. Many lanve. especially the hairy ones, will look well if earefully prepared in this way. A considerable number though look anything lout like the natural caterpillar.

I have tried another methor with success, which. reguiring little more skill, is much more satisfactory in its results. Treat the caterpillar the same as if it were to be inflated with air, lut instear, inject into it hot paraffine or beeswax, colored to resemble the contents of the natural insect. This is done as follows: Proeme at the drug store a small collapsible rublyer syringe (the ball and tubing eonnected with an atomizer for perfume will answel as well), and into the opening insert a piece of small luass tubing, luving a small steel spring attached to hold the larva. I'urchase a quantity of paraffine or white beeswax, put it in a tin with boiling water, and when melted add the proper coloring ly mixing with it oil colors from a collapuible tube, such as are made by Winsor \& Yewton and procurable at any store where artist's materials are sold. Now draw boiling water up into the syringe a few times mntil it is thoroughly wamed, and then quickly fill it with the lot paraffine and inject the skin of the caterpillar (which should have been previously placed in warn water) to its nornal size. If the larva is now put into cold water it will soon harden and will keep its shape. If the paraffine is of the right color, the resemblance to the natural insect will be very striking. Specimens treated in this way are lutrd but are not nearly so brittle as those inflated and dried with hot air.

Of course, either method requires some eareful manipulation; but with a little practice the results, especially with the paraffine, are encouraging. The resemblance to the natmal caterpillar will be still nearer if the skin ean be painted wherever warts and spots occul. These are frequently red or hlue, while the gemenal surface is green. But this belongs more to the professional, and skilful painting an hardly be expecter from the amateul.

The eloysalides and cocoons of different kinds are not difficult to preserve and usually look pretty well if simply llied. Some of the translucent ehrysalirles will be improved if the contentis are talken ont at the back and the space filled with colored wax or laratfine. 


\section{TIIE CAIINET.}

('aloinets may he made in a valiety of ways with drawers large or small, lut they need not be more than one inch deep inside. Basswork makes a nice cabinet as the wood is very light and does not warp so batly as many other wooks. The front of the drawers and the front, top and sides of the case may he marle of some liard wood, such as oak ol elerry, whirh will take a handsome polish. A useful calinet, ancl one which looks well, too, may be marle of the following dimensions: Fon feet six inches ligh, four feet wide, and two feet six inclues deep, from front to back. Two doos in front and a double low of dlaw wors from top to bottom. Ilowever, the cabinct should eorrespond with the owner's taste and what it is intended to illustrate. One may liave a very small cabinet and yet with room to spare which will contain the ream of the hutterflies of the world. 1 gool many. in fact nearly all butterlies will farle perceptibly if exposed to the light for years, am some of the most delieately tinted mothe lowe all their beanty if so exposed for a short time. Therefore they must be protecterl from the light.

Shatlow woorlen boxes answer nicely for storing the colleetion temporarily. 'These may be made very inexpensive, and look well if of uniform size. 'T'o own a handsome ealinet for his eolleetion should be the aim of every collector. 


\section{HOW TO MAKE A COLLECTION.}

\section{COLLECTING BUTTERFLIES.}

To make a successful collector of diumal lepidoptera requires agility and a practised eye. One soon learns to manipulate the net so as to capture the specimens on the wing almost exclusively. This is preferable as the net is less liable to be torn and the insects are taken in more perfect condition than when captured while at rest. After capturing a butterfly and retaining it in a fold of the net, carefully place its wings together back to back, and give the thorax a sharp pinch between the thumb and finger. This will in most cases render the insect inactive and it may be turned out and into the poison jar without injury. It is a good plan to put the specimens in collecting papers before placing them in the poison jar if they are large and fine, as this will protect them from injury by rubbing together. Another scheme which answers admirally is to place small pieces of tissue paper over the specimens as they are put into the poison jar, so that fresh additions may not injure the ones already captured. There will be little necessity to touch the wings of specimens with the fingers when once accustomed to the work; and as more damage is likely to be done at the time of collecting than at any other, care in handling will make a marked difference in the appearance of the collection as a whole. It will rarely be necessary to run much for the insects one desires to capture, for by watching favorable opportunities they may be swept into the net with little more than a few quick steps and a rapid movement of the hand in guiding the net. Some butterflies, however, fly long distances when once on the wing, and one will sometimes get a long rum and a glorious sweat in making such a capture. One soon learns to distinguish. while the insects are flying, between fresh specimens and those which are worn or torn; and this, it is scarcely necessary to say, will save the collector many needless steps. Collecting with the net may be commenced very early in the spring, as some species make their appearance before the snow is all gone and from that time on one may find new species coming out every few days.

Low, grassy mearlows, with elumps of bushes, are generally farolite launts of many butterfies. The different species of Arymnis, 


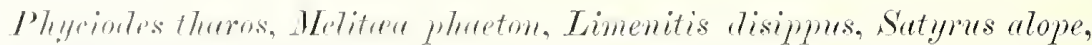
Nommmplue conthus, with two or three speeies of the genus Thecla and many moths, are found in such localities. As the ground is frequently very wet in such places. one must go preprared or else lut nl, with wet fuet. The hntterflies to be found in the upland fickls are anomg the most common we lave, Pieris rape, Colias

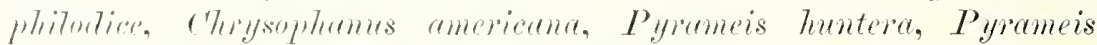

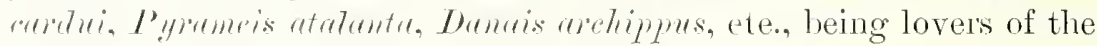
open fiolds. Fields of clover and patches of milkweeds and thistles me partionlarly attative to the species named.

I well rementher a noglected pristure where thistles and milkweeds grew in seattered clumps, where I have passed many an lour with

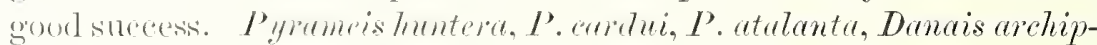
pus, and sereral smaller butterflies flew from blossom to blossom, and were sometimes so intent on extrating honey that I pieked them off the flowers with my fingers. The hours between ten in the morning and three in the aftermon were the most favolable, and beantiful fresh sipecinens were to he found there almost every day. Sueh a locality, if known to a collector, will funish him with a great many splendicl insects. Among such a number one need take only the most heantifnl and perfect, and the duplieates ean he used in exchange witl foreign collectors for their treasures.

Roardways and along brooks and rivers are sometimes excellent localities for collecting. Butterflies seem to like to fly along roads ant ruming streams, partieularly the l'opitios, Limenitis arthemies and $J$. wrulle. They will also sometines congregate on the muddy bankis of rivers or about mudkly pools in the road where a dozen or more may be taken by one sweep of the net. Several species are in the hathit of visiting lrarnyards, and decaying sweet apples and pears are an irresistible bait for Limenitis upsule, Gropta inter-

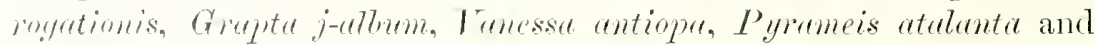
Tranesian mitherti.

In the town of Mentor, O., where I passed a portion of my ehildhom, there was an old cirler-mill, and from the time the first sweet mples ariver and were enthiser until late in the fall, on every fine diay, clusters of hutterfies conld be seen resting on the heaps of refuse and eagerly sipling the lanf-fermented cider. What a place that was for a boy with a net! I have seen twenty Limenitis ursula, resting on one heap of "apple chankins," opening and closing their: purple and black wings in the sunshine, while several other 
species of handsome butterflies were no less numerous. At the approach of any one they rose in a swarm, some resting on the sides of the old mill, while other's continued to fly until the danger was past and then settled once more to the feast. It would be difficult to tell which occupied the greater part of my attention, the butterflies or the cider. Suffice it to say, that both I and my collectingjar went home pretty nearly full after a few hours passed at the old cider-mill.

The tops of hills and low mountains are frequented by butterflies; and often when the sides of a hill are poor in both species and individuals, they will be found plentifully on the tops. especially if there is a cleared space in the forest occupied with slumbs and bushes where they may fly about. At such times they may be seen flying in regular circuits, and two or three will often chase each other up' into the air until they are almost lost to view.

I remember such a hill near Sonora in California. Starting with a fellow-collector early in the morning of May 15th, we arrived at the top of the hill about nine oclock. We had seen few butterflies on the way up; but on reaching the top, we found them in hundreds. The air was filled with them, they rested in dozens on every bush. There were not a great many species, perhaps not more than seven or eight kinds in all; but of these we could have taken almost any number, and I caught two cigar boxes full of perfect specimens - perlaps two Inndred and fifty insects - before dinner time. A large number were imperfect; and we found a good mant dear and dying ones on the rocks and ground. 'The lizards and ants were making great havoc among the weak and sickly ones, and the ground was hitered with their wings. Why they had so congregated I cannot inagine. The gentleman with whom I went informed me that he lad found them in this place several years in succession, at the same season of year.

The different species of Parnassins are mountain-inhabiting butterflies, and are usually found far up on the sides of high mountains. We have several mountain butterflies which are to he found upon the bare and inhospitable tops of the White Mountains in New Hampshire. Mountain valleys are usually very rich in butterflies; and on a roal traversing such a valley the collector will sometimes find a veritable paradise for his labors.

Some butterflies are very combative, and will give chase to every flying object that comes in their neightorhood. 'They will even fol- 
low to near the earth anything which is thrown into the air; and often I lave copturerl insects which persisted in alighting far out of the reach of my net, by throwing my hat in the air and taking them as they followed it down.

Whan collecting in the woods where butterflies are wild and fly high, one may materially increase lis captures by using a decoy, by pinning a deat specimen with its wings spread, in a conspicuous likere, the top of a low bush with the leaves stripperl off, for instance, and, standing rearly with the net, the butterflies may be taken as they dly down and hover over the decoy. $\Lambda$ live decoy may be used in the same manner by tying a threal around the body of the insect between the alxlomen and the thorax and allowing it to flutter about where it can be readily seen. 'This method I have used very successfully in tropical countries to capture the superb but wikd and high flying I'apilins and the gorgeous Ormithopters. I lave sometimes been olliged to show with a shotgun the first specimen for a decoy. A piece of cardboari painted to resemble a butterfly I have seen answer for a decoy, and it has the advantage of durability.

of some sprecies of butterflies the males will be found to outnumber the females three to one or more in the specimens taken. That there really are so many more males than females I very much douth, as in rearing specimens from the eggs or the larve the sexes seem pretty evenly divislerl; hut possithly, on account of the males being more active and flying more in the open or being frequently more showy, the collector will almost invariably take more males than females of a given species. This discrepancy is shown in the eatalogues of those who have butterflies for sale, where the females of some species are often two or three times the price of the males.

The females are usually much larger than the males, and are sometimes, thongl, rarely, richer in their coloring. The males of some species may readily be distinguished from the females by noting the clasuers on the end of the abdomen of the former. The females frequently have larger bodies than the males, their abdomens being distenterl with eggs. There are a good many kinds, however, where these distinctions are not readily seen and the sexes are difficult to separate. In some species the sexes very closely resemble (ach other, while in other's they differ so much as to look like totally different insects. Take Aryynnis aybels and Tenesse antiope as examples of the former, and Shaturnin in and Attucus promethin as representatives of the latter. 
For a collector to capture one hundred species of butterflies in a day in some parts of Mexico. Columbia or Brazil is not an unhearl-of thing; but here we have to be contented with a much smaller variety, and to take ten or twelve kinds in good condition is a good day's collecting.

\section{WHEX BUTTERELIES ARE MOST ABUNDANT.}

June, and the latter part of August and the first of September are the best times of the ycar for collecting in the United States, although many kinds are to be taken at other times.

Between the latter part of .June and the first of August there is generally a dearth of specimens, except of the different kinds of Argymis, which are most abundant about the middle of July. This does not apply to the mountain distriets, as excellent collecting may be had in the vicinity of Mt. Washington, X. H., the Berkshire Hills, Mass, the Adirondacks, N. Y., Blue Ridge, Va, and the ()zark Mountains, Ark. in July, where a dozen species of butterflies will be found in their prime at that season. The reason for this searity of butterflies when one might expect to find them most numerous is that the first brood has all hatcherl and gone, and the second is at that time still growing in the larval state. A collector may go out with his net at such a time and be well-nigh disgusted at the poverty of a locality which at former seasons has yielded lim a fair larvest for his labors. How dull and uninteresting are the fields of grass and clover where not even a common yellow Coliss or a white Pieris flits across the landscape to gladden his eyes. P'lenty of mothis may be had at this season, hut the butterflies are searce.

I am often asked by persons interested, " How long does a butterfly live?" My answer is: "Some speeies only a few days, or a week or two at the most; some hihernate and live in a domant state several months, but their life of activity is very short; a butterfly is at its best only two or three days." 


\title{
COLLECTING MOTIIS.
}

\author{
ASSEMHLING.
}

'This name is given to a method of bringing together numbers of the males of any species of insect hy the aid of a virgin female of the sime or an allierl species.

The different species of the limily Bombyr may be realily assemherl, and a more interesting experience to an enthusiastie collector ean sourely be imagined. Some of the species assembled with little diffenlty are anong our largest and most handsome moths. Suturnia

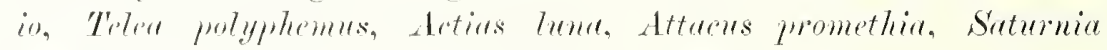
maia, etc, are all easily assembled, the methor of procedure being as follows: 'Take a virgin female a few hours after she has hatehed from the coeoon, and place her in a hag male of mosquito netting. IIng the bag ont of dons om the limb of a tree or other suitable place, and have a light near enough so that you may see the males when they arrive. A wam, dark night with a light hreeze blowing will be found most produetive; and when the males begin to congregate the collector will be husy indeed if he manages to cateh and take care of half the speeimens that come. Sometimes they make their aprearance early in the evening, at other times later, and one nunst do his hest when the dance begins.

In experiment which a friend of mine assured me he har tried with excellent suecess was on a warm afternoon to take the eaptive female with him on a ramble through the forests and fields, making a eirenit of two or three miles abont his home, and on returning hang the moth out of doors near his house as usual. He said he had very goon reason to think that the males in flying about in the evening came across the scent left by the female as he carried her, and on following it up arrived at his honse, where he was on the lookont for then. Ilis success leats me to reeomment this method to the collector, as my friend evidently puts a great deal of faith in it.

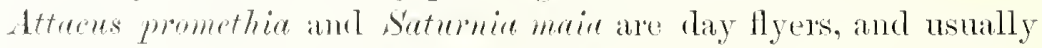
assemble best on warm afternoons, when they may sometimes be taken by dozens. It frequently happens that the first night after hatching a female will not attract the males at all, while they will come in numbers the second night. A good deal seems to depend 
on the condition of the atmosphere; for on some nights the scent does not seem to travel well, and on others it must go for miles. juilging by the number of specimens that follow it up. It is a fine sight and one worth losing lalf a night's sleep, to see these great moths, from two to a dozen at a time, circling abont the trees or alighting on the grass, all eager to pay lomage to the gentle laty in the net. She generally remains quiet or gives her wings a gentle tremulous motion, presmmably to attract her dilatory lover, whom she has good reason to suspect las deserted lier for some other fair virgin.

One particular evening when we were boys, my brother and I stayed up nearly all night capturing the moths that came to one captive female. Teleu polyphemus. My mother came out alont mirlnight to tell us that we must stop and go to bed: hut she beame so interested that she not only gave her consent to on remaining at the work, but actually got her net and joined in the excitement. W'e took something over two liundred perfect specimens of the males that night. It is a splenclicl way to capture large and fine specimens for the cabinet, and also to get reries slowing variety of coloring.

To see Actirs lmo, that lovely pea-green gem of the night, assemble in numbers, is an experience not soon forgotten. The female of this species should be taken to the edge of a forest containing walnut or birch trees and placed in position hefore dark. One must keep a constant watch over the prisoner, as birls and bats think of entomological specimens only as savory morsels for a meal, and will not seruple to tear the net open to get at the prize, as I have known them to do on several occasions much to my dingust.

But to go on with the methods for collecting: 'Take a lantern, a net and a poison jax, with a box or a small satehel and plenty of papers. If the night is favorable and the female in the right condition to give off the seent, a very interesting time may be expecterl. The moths are so light colored that they look alnost white in the light of the lantern, and as they flutter down from the trees to where the female is held captive one will almost hold his breath for fear of frightening them. 'They are not wild, however, and do not seem to notice the collector and his net and lantern.

Cats and skmnks take arvantage of such chances of procuring a meal. and I rememher once having left ont all night a fende moth in a net, and looking ont in the molning to see my lawn strewn with the wings of hundrerls of moths which the cats liad lilled and eaten. 


\section{COLLECTING WITII A LAMP.}

(On wallm, moonless nights, especially if clourly, moths are attrutal towarl a bright light, amb many insects rarely seen at other times may be taken in this way. A seeond-story window overlooking lawns and cultivater fields, not far from forest trees, makes a good place to toy. 'The lamp should be one which gives a large and bulliant light and be placed on the window-sill with the window wille opene so that the moths maty come into the room, where they may be taken with a small net or captured in the poison jar as they lest on the walls or the ceiling. 1 piazza or baleony with a lamp on a talle will sometimes be fomm to answer the prupose well. In that case place the table and lamp against the sirle of the house, so that the moths as they tly about will alight on the clapboats near the lamp, where they may be easily eaptured. The side of the house araly from the winl will be found most favolable for this mode of rollecting.

'The grood nights for taking motls in this way are not numerous, and one must make the most of them when they come. Collecting in this manner maty he carried on from early May till late in October if the weather is favolable, lifferent species making theil appearance at clifferent times. The variety thus to be collected is almost andless, and comprises moths flom the minute mirro-lepidoptere up to the griants of the lave, six or seven inehes in expanse of wings. One som learns to recognize the different species by their modes of flight, as they bump, their hearts on the ceiling of the room in their strange levilkement. When some much-prized moth enters, close the window, as I have known many a fine specinen to change lis mind about alorning one's cabinet with his precious boly and fly out of the open winklow much faster than he came $i n$. 'To lose a rare and beantiful moth is a keen disajpointment to an enthusiastic collector, and such a mishap may often be avoided if this simple precantion be taken.

One may sometimes make graml aptures abont electric lights, even in cities, by visiting them on warm summel evenings with the net and poison jax. Sphinx moths, which rarely come to a lamp, will often be seen flying in wirle eireles about the electric are lights; they are then not very shy and may be easily taken. 
While employed in Washington, D. C.. I made a splendid collection of the moths of that region simply by going the rounds of a number of electric lights every evening. The lamps about the Treasury Building were sometimes very productive of fine specimens and the broad stone steps and pillars were frequently littered with moths, May flies, beetles, ete., where one could stand and piek out his desiderata with little difficulty. I eaptured several of the Regal Walnut moths (Citheronia regatis) and a number of our largest and handsomest sphinxes. Besides making the acquaintance of a number of insects new to me, I met several entomologists who, like myself, had been attracted to the lights by the abundance of specimens.

\section{SUGARING.}

A favolite manner with many collectors of taking specimens is by sugaring or smearing trees, posts, ete., with a strong mixture of rum and molasses, and taking the half-intoxicated moths with the poison jar. This method may be successfully practised during the summer and autumn and will add many new species to the collection.

The mode of proceeding is as follows: Get a pint of strong. dark molasses and boil it down until it is as thick or thicker than ordinary house-paint or gruel. 'To this ald a quantity of rum, whiskey or' other strong alcoholic liquor. Care should be taken, howerer, not to put in enough to make the mixture too thin or watery. After tying a rag on the end of a stick, by way of a brush, the collector is ready to sally forth. Select a locality not far from the wooks. and before dark smear the trunks of trees, fence-posts, etc., with the mixture. At dusk the moths will begin to arrive, and the collector, providerl with a lantern and a poison bottle, should go the rounds. If the locality is a good one and the night favorable. numbers of moths in all stages of intoxication, from "milaly hilarious " to "comfortably drunk," or even blissfully ignorant of everything about them, and too far gone to be able to wind up their extended tongues will be found about the bait. They are at these times easily taken, simply by placing the poison bottle under them and knocking them into it.

Many Noctuide and Phalcenide come to such bait, and I know of no better manner of procuring the different species of the large and handsome Catocald. Most species of this genus may be 
taken in this mannel from the midrle of August until cold weather. It is useless to try this bait where flowers are abundant, and moths will not come on cool or windy niglits. The same trees may be smencer night alter night with good results. A small box containing sheats of cotton batting cut to fit it is very useful for this mode of collecting. Alter a mumber of motls are captured in the poison jal, they may be turned ont into the box and carlied safely home hetween the sheats of cotton. It is hest not to allow the moths to remain too long in the poison jar, as they are apt to rub their scales oft', very nutch injuring their al'pearance.

\section{COLLECTING ABOUT WILION BLOSSOAS AND GARDEN FLOIFERS.}

When the catkins of the willows are in bloom they attract a great many moths: and the collector provided with a bull's-eye light and a

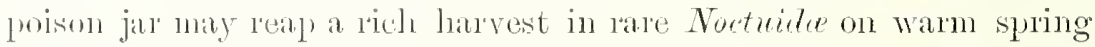
evenings. So intent on the Iepast are many of the moths that the net will selklom be neerted. I have in mind one near-by locality where, after a warm day in sumg, the moths may be collected by Jozens on the willow catlins.

Miny species of looth bntterflies and mothis ane attacted by flagrant flowers. The lilae, phlox, petunia, syringa, pink and many other common garden flower's are resorted to by butterflies and dayflying splinx moths in the daytime, and by moths of many kinds at dnsti and late into the night. A bull's-eye lantern and a net are needed for their capture after dark. Some of onr largest and handsomest inseets may he aptured in this way, as they remain poised on the wing, tongue extended, extructing the nectar from the flowers. Somo of the sphinx moths are very slyy, and are liable to leave if the rays of the lantern are turned directly on them. They are apt to fluther a great deal after being captured in the net, so that they shomld be taken ont and quieterl as soon as possible, else they may luin theil alpealance enteavoring to escape.

I have taken in this manner in a single evening over forty sphinx moths, lepresenting eight species, near one hed of phlox. In some localities I have no donbt that this number can be exceeded, or even doubled, by one who murterstands the captnoc of these fine insects. 


\section{COLLECTING CATOCALA.}

Catocala are sometimes found in numbers in the forest on the trunks of trees; and when a collector is fortunate enough to run across such an assemblage he should make the most of the opportunity, as it is not likely to occur very often in one's experience. 'The different species of catocala so closely resenble in color and markings the bark of certain trees, that it is next to impossible to see them. Oak groves seem to be their favorite haunt, and the tree trunks for the space of an acre or two are sonctimes well peopled with them. They are so shy that one must use the greatest caution in their capture. They are best taken by placing the mouth of the poison jar' over them as they lie with folded wings feeling secure in their striking ataptability in color to the moss-covered bark. Many species may sometimes be taken in one locality; but they are all wild and very rapid flyers, so that it is difficult to capture them on the wing. It is best not to molertake their capture with the net for another reason: I refer to their liability of injuring themselves in their desperate efforts to escape. A poor specimen is little bettel than none at all for exhibition purposes; in fact, I regard one really beatiful, perfect specimen nicely mounted, of more value than one dozen worn and mutilated ones. 'To riew a collection of fifty fine and perfect inscets will give a naturalist more pleasure than to look over a whole cabinet full of rubbish collected with no eare and mounted in a slovenly manner.

The greatest eare is necessary in handling the cutocolle as their scales come off with a touch, leaving bare and unsightly patelies. Catocala cara and $C$. concumbens are often found under bridges over river's and brooks, hanging back lownwards from the hoards or stones. One bridge a mile from my home has funished me with many excellent specinens of the two species named; and I rarely go there in the season but I find from ten to thirty of these inseets. It is useless to look for them in such localities before the midule of August. The same species may also be found on the mnderside of tree trunks which overhang the water.

The catocald often frequent rocky ledges and stone walls where the gray color of the upler wings of some species harmonize with their surroundings. 


\section{GATHERING CIIRTSALIDES AND COCOONS.}

The lauve of many moths go into the ground to pupate, where they remain (many of them) during the winter. At the approaeh of wam weather they work their way to near the surface where the perfect insect can easily lind its way out. It sueh times they are easily foumd hy raking over the fallen leaves moler the trees in elose furoximity to their trunks. Seattered groves of large trees are likely localities in which to hunt for ehrysalides in this manner: and pines, oalis, poplans, willows, elms, etc. are reasonably sure to furnish treasure for the searehing.

A stout, forked stick makes a good tool with which to work, and a hox containing leaf monld answers well for a depository for the specimens, in which they may be left until the flies emerge. The cocoons of a valiety of moths may be found attaeherl to the twigs of the trees on whiel the larva feed, after the leaves lave fallen in the autumn. Wild dherry and sassafras will sometimes be found with a number of cocoons attached, while oaks, elders, hirches, maples, and numerous other tress and shrubs will eaeh yield their reward for diligent search. 'The naked chrysalides of butterflies are often attaehed to fenees, walls and houses besides the stems of the food plants of the larva. The chrysulirles of many butterflies are exeeedingly diffienlt to find, and with some speeiss it is only by most diligent search that suceess may be attained. If one wants to make a trial, let him begin with one of our nost common butterflies, Colias philodice, whieh abounds everywhere in fields and meadows in summer. See how many loms of patient exploration are necessary to find the first chrysalis: while to locate in the pupata stagnnis iluliu, Meli-

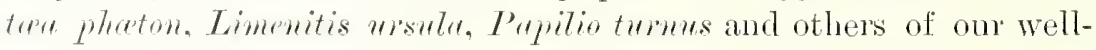
known butterflies may require many days of study and eareful seareh.

\section{TO REAR SPECIMENS FROM THE EGG OR THE LARVA.}

Many specios of lepirlopterous inseets are easily reared from the exgon the larva.

One mal procure the eggs of some butterflies and moths simply by enchosing in mosquito netting a fertilized female with a braneh of the plant upon which the larva feed. Some insects, however, eamot 
be induced to lay their eggs in this mamer; and sometimes it is only by watching the female at liberty depositing her eggs that they may be had at all. Many of the eggs are smaller than the head of a doll's pin, and are frequently attached to the underside of the leaves of the food plant, so that diligent and careful search is necessary to find thenr. Most of them are covered when first laid with a gum or varnish which when dry seeurely fastens them to the objects upon which they are deposited.

The number of eggs laid by a single female varies from one hundred to five or six lumblred or more, according to the species. They are often haid singly, especially by the butterflies: but a large number of the moths deposit their eggs in a compact patch and in regular rows so close together that they touch each other on all sides.

The eggs deposited during the warm days of summer soon hatch, while those of autumm remain mohanged until the following spring.

The heat of summer and the cold of winter seems to have no injurious effect upon the eggs of lutterflies and moths: and if it were not for the army of creatures whose life work it is to keep these hosts in check, every green thing in the way of vegetation on the face of the earth would be devoured.

Just before hatching, an egg frequently assumes a leaden hne, and the young larva eats his way out of his prison and escapes, often devouring before lie goes the egg-shell which has sheltered him. At this stage the larva is frequently very unlike the mature caterpillar. He should now be placel in a glass jar with an inch or two of moist loam at the bottom, with young and tender leaves of the food plant. He will have a sufficiency of air if the cover is kept on, and the leaves will be kept fresh longer. Care should be taken not to place the jar where the direct rays of the sun will shine on it, as the temperature may become too great. One may introluce into the jar a small bottle of water, holding the leaves if this is desired; but the mouth should be plugged with cotton or the larva may fall into it and be drowned. The caterpillar will grow rapidly, and will require a good deal of fresh food. For this reason it is best when it is onethird grown to place it on a branch of its food plant and enclose the whole in mosquito netting.

In rearing quantities of larve a harrel without either heal may be placed over a bush and all the branches brought up through the top. Then after enclosing the branches which protrucle in mosquito netting and introducing the larve to be reared, fasten the 
netting securely round the top of the barrel. This simplifies the rearing of lanvere and gives them conditions ahmost exaetly the same as they prijoy in a free state. A great many spreeimens may be reared at one time in this simple mannert.

If the insects are earth-loving species and desire to complete their transfomations in the gromul, they must have an opportunity to do so, and should be plareel in a box with loam when fully grown.

Many will spin cocoons, other's will attach their naked chrysalides to the twigs of the fook plint. (ireat care must be taken with the larve to protect them from their matmal enemies, the ichnemon flies, which are comstantly on the watch for an oppontunity to deposit their "ages in or" on them. Fon this reason they shomld not be exposer ont of dool's muless covered with fins-meshed netting.

The coeones may be kept in a worken box in the cellar during

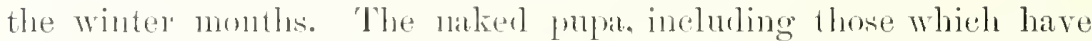
transformer in the soil, may be placed in tin cans (ordinary fruit ("alls will answer') without any soil or loam and kept in the cellar also. These shomlal have the eovers put on to prevent the pupe becoming tou dry, as they are almost sure to do if not eovered tight. In this way their preservation is a simple matter, and their loss by drying or monlel is completely done away with. In the spring the cocoms maty he tied on strings and humg in the attic, where they will latche without troulde.

The naked pupe may also be removed to the attie and allowed to renain in the tin cans until a short time before the fly should emerge, when the phl he may be placed in a good-sized wooden box, on (not in) clamp, earth. with a fow leaves covering them, and allowed to hatch. The box may be covered with netting to prevent the eseape of the perfect insects. A few twigs placed among the chrysalides will enable the newly hatehed flies to suspend themselves so that their wings will develop, in the normal mamert. 


\section{CLASSIFICATION.}

Tue following order of classification, arlopted mostly from that of Mr. Henry Edwards, will be used in this work.

ORDER LEPIDOPTERA. Moths and Butterfies.

Sob-order IIETERocerd. The Moths.

MICRO-LINIIn)TERA.

PTEROPHORID,E

TINEIT,E

Plume Motlss.

TORTRICHLE

PYRALIUEE

'Tue Noths.

Leat Rollers.

sinout MLoths.

MACRO-LEPIDOHTEIR.

GEOMETRLD.E

NOCTUID.E

BOWBYCIDLE

$Z Y G . E N T D, E$

$A E G E R I D \perp E$

SPIIINGIDE
Loopers or spanners.

Owlets or Moth Millers.

spinners.

Zyganids.

Glass-wings.

Dusk-flyers.

Sub-order Riropalocera. The Butterflies.

IIESPERID $E$

$L Y C, E Y I D, E$

SATYRID E

NYUPIIALIDE

$P A P I L I O N I D E$
Skippers.

Blues, Coppers, Hairstrealss.

Woor Nymphs, Browns.

Angle Wings, silver spots.

Whitelings, Yellows, Swallowtails. 


\section{HETEROCERA. The Moths.}

In this groul, of insects the antenne are of various shapes, generally terminating in a point, while the wings are usually folded roof shape over the ahdomen when the insects are at rest.

Many of the species have anistle attuched to the upper edge of the hind wing near the hody which fits into a loop in the lower edge of the uplee wing for the purpose of holding the wings together dur. ing flight. By tuning the inseet mpside down and spreading its wings the lnistle and loop may be reatily seen.

Many of the sleceics are extremely minute, the aid of a mierosoope being necessary to stulty them, while a few are gigantic in compratison, heing among the largest and grandest insects knowr.

Many are platin in color or their coloring is soft and blended, while a fow rival the gavest and riehest butterflies. Most of the species tly by night, a fow love the hottest sunshine, while others prefer the dusk of monning and evening.

Theil geographical lange is very gleat. They abound in the tropics in eomtless myriads while species of this group have been reen in the cold and harren wastes of the most northern polar lands. 'They are fomst in every land and under all conditions of climate, wither as the perfect insect ol as the egg, larva ol alusalis.

home species make coeoons in which to pupate; many burow in the gromml or hide under leaves in the forest.

Most of the aterlillars of mothis foed on the leaves of plants, some in the stems ancl trunks of trees, while some devour fruits. The small kincls, polubly best known to the thrifty housewife, devour woullens, feather's and fin's.

'The moths nutnumber the butterflies many times and between five and six thonsmal species are natives of Ameriea north of Mexien.

'These insects are nealy all, excopt the silk prorlueers, directly injurions to man's interests: the parasites and insectiverous birds and mammals keeping thene vast hosts in check. 


\section{I RO-LEPIDO T TERA.}

A few only of the innumerable species belonging to the four grouss representing the micro-lepidoptera will be mentioned and figured in this work. The detailed study of these minute creatures belongs to the specialist, and even he can only lope to becone well acquainted with the species of a few genera.

\section{PTEROPIIORIDE.}

The Pterophoride, or plume motls, have the wings divided into plumes or feathers. Their bodies and legs are slim, and the creatures are so delicate as to be difficult to capture and preserve without injury. Most of these insects are night flyers and may be met witl from early in the spring till late in the fall.
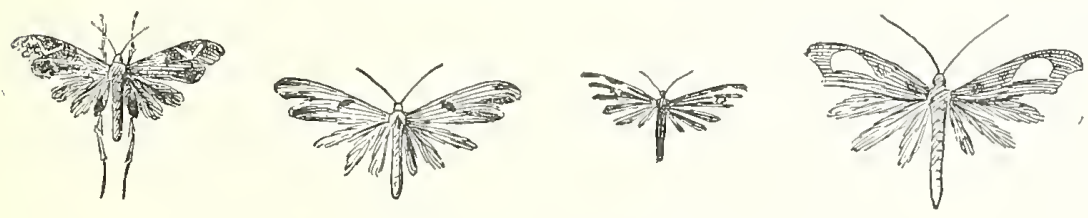

Various Forms of Plume Moths.

The caterpillars are lairy and spin no cocoon, changing to a naked chrysulis suspender from the end of the abdomen. The chrysalides of some species of these mothis are also hairy.

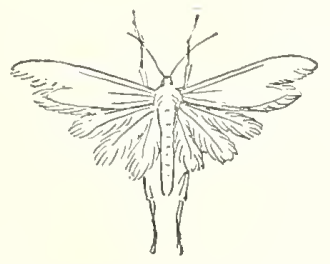

I'teropliorus pentaldactylus.

The white plume moth (Pterophorus pentatentylus) is not a common inseet in the East, but I lave taken it on a few oecasions with a lamp in June and July, and lave seen it often in Northern Ohio and Virginia in those montls. It flies slowly and is so exceedingly 
flagile that the greatest care is necessary in hantling it. The larva is sail to feed on the temler leaves of the convolvulus; but I have never seen it and know nothing of its habits. 'The moth has an expanse of wing of about seven-eighths of an inch in a good-sized specimen, but is often smaller. The upper wings are two-lobed or 1)huned, and the hind wings three. 'The insect is often a pure silvery white. Sometimes, however, its wings are sprinkled with a few gray scales. The legs of the moth are so long, and it stands so high when at rest, that it bears a slight resemblance to a crane fly, and womld havelly he thought to be a moth at all hy the novice.

We have a number of sleeies helonging to this family but this is one of the largest and most easily recognized.

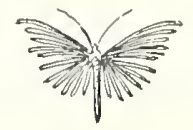

Alucita hexadactyla.

The six-plumed moth (Alucita hexalactyla) is a common American species, being also fomol in Europe. Its expanse of wing is about half an inch, and each wing is six-phumed, being yellowishgray in color with hrown markings, and a black dot at the end of each feather or lobe. 'The caterpillar feeds on the flowers of the loneysuckle, is of a redish-salmon color, and, mulike most of the other species of this grouly, spins a silken cocoon. 'The moth is said to hibernate during the winter.

\section{TINEIDAE.}

'The Tincille are mostly very small moths, and the number of species lelonging to the gromp is very large. Many of these insects are gayly, some magnificently, colored: but a microscope is needed to see their beanty. 'Theil' wings are narrow and pointed, and are fringed with long delicate hairs. The larve of these moths are minnte creatnes; and many of them are leaf miners, so called becanse they burrow in the leaves just helow the surface, and make lomg and chooked passages videning as they advance. Some species bore in plant stems, some attack grain stored in lonses, some mine in the roots of plants, some few liroduce galls, and some make sad havoe in our louses anong woollen goods or feathers, if left where they can procure access to them. 
Tined flacifrontella, - the common clothes moth, is found in our houses in summer, and may frequently be seen flying about our apartments at night. It is of a light yellowish color and has a silky appearance.

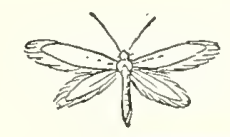

Tinea tlavifrontella.

The larva is whitish and does great damage to woollens, using the material on which it feeds to make its pupa case.

Numerous moth destroyers are used to exterminate this pest. Camphor, naphthaline, benzine, snuff and corrosive sublimate may be all used with effect; but common kerosene oil is perhaps the simplest, cheapest and most effective. When woollens are to be put away for the summer, sprinkle kerosene oil profusely in the bottom of the trunk or box in which they are to be packed and after it is filled lay over the goods a paper saturated with it and close the whole up tight. When it is desired to use the clothes once more, a few hours" exposure to the air and sunshine will remove all smell of the kerosene.

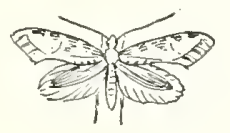

Tuuea granella.

Tined grenelle is a creamy-white moth with brown markings on the upper wings one-hatf an inch in exposure, and the larve live in our granaries, where they entail great loss if left undisturbed.

The female moth lays its eggs upon the grains of wheat, and the worms eat their way into the grains, reducing them to shells and binding masses of them together with their webs. The larrat, according to Curtis, makes a cocoon composed of web and wood-pulp in which it hibernates during the winter, changing to a chrysalis in the spring and soon after emerging a moth.

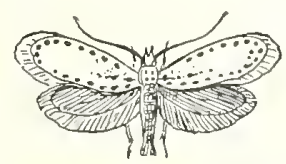

Hyponomeuta millepunctatella.

In IIyponomenta millepunctetclu the larve are gregarious and spin cocoons. The moth is three-fourths of an inch across the 
exprunded wings, the fore wings being white with black dots, the linel wings dark gray.

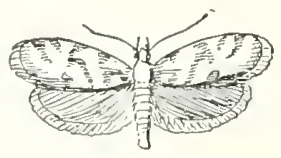

Depressaria robiniella.

Depresseria mominth. This moth expands three-fourths of an inch. The hear and fore wings are redilish-brown spotted with yellow. 'The hind wings and holy are gray. The green larve live on the leaves of the loeust and shin their webs among the leaves drawing them together'. 'They are vely active creatures and in searehing for then by pulling their webs apalt they are very liable to wriggle away. 'The larva are said by Packart to pupate among fallen leaves on the gromel.

The genus Nepticuld contains many very minute and yet many very heantiful species. 'I'o this genus belong the smallest of all linown lepidopterous inserts, many of them less than an eighth of an inch in expanse of wing. The lanve of these minute insects mine in the laves of different species of trees.

\section{TORTRICIDE.}

The leaf-rollers. so called because the larve of most of the suecies of this group of moths form the ends of leaves into rolls for their potection, are a numerons family, represented by many species in this enuntry.

The fore wings of these moths are broat and are often brilliantly colored, while the lind wings are ustally sombre.

some of the larger species are gregurious in the larval state. nuiting a number of leaves by webs, anong which they feed and
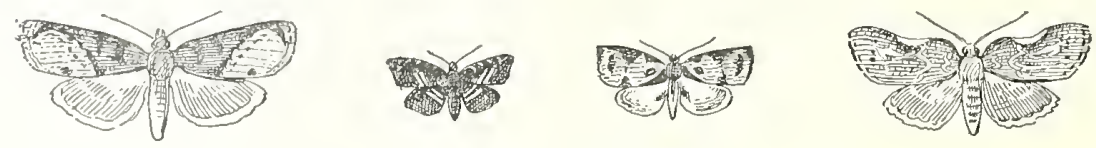

Farious For us of Leaf-rollers.

finally purate, leaving the empty shells of their chrysalinles protiuding from the wets. 
Lozotenia cerasiovorand is about one inch across the expanded wings, which are of an ochre-yellow color crossed by brownish markingss.

The larvie of these insects are gregarious and live on the leaves of the choke-cherry, their unsightly nests with the yellowish-brown shells of their chrysalides attached to the outside of the wels by their posterior ends may frequently be seen by the roadsicle. 'The moths often remain abont or upon the nests several days after hatching.

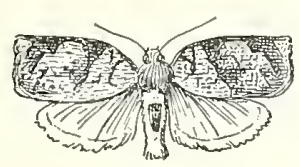

Lozotrenia cerusiororana.

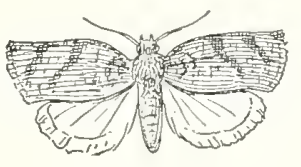

Lozotæuia rosuceana.

Lozotenid rosteedna expands nearly an inch in a fine specimen. The fore wings are light brown crossed by bands of reddish-brown and the hind wings are light yellowish brown. The larva is said by Packard to bind together the leaves of the rose, apple and strawberry with a few silken threads. The insect is double brooded, one appearing in June and another in Angust.

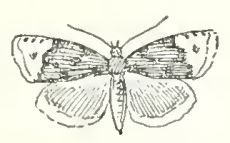

Intithesia pruniana.

Antithesid promiana is five-eighths of an inch in expanse, and the fore wings are marbled with black and like with white on the outer portion. The larva lives on the plum, and is a native of Europe as well as this country, doing consirlerable damage.

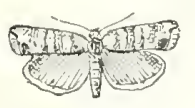

Carprocupsa pomoutla.

Gapocepsed pomonella is the famous coddling moth, the latrie of which often does so much damage to the apple and pear 'ropl. living in the interior of the fruits and cansing them to drop to the gromed when only partly grown. The moth is half an inch in expanse and is dark brown in color. 


\section{PYRALIDE.}

The Pyralida, or snout motlis, may be reeognized by the long fore wings, their long legs and elongated bodies. Many of them atso have the galpi very much elongated, from which they derive their common name. Some species are day flyers, others fly at dusk amb still others fly at night anl ane purely nocturnal. Some of them are white and silvery in appeance, while their wings are bortered
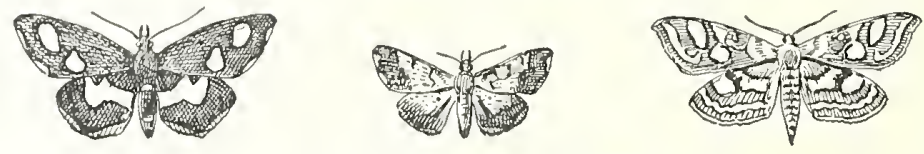

Varions Forms of Snout Moths.

or streiked with bands of golet, others are gray or brown, often of a silky lustre, while some are black with white spots. While at rest many species fold their wings close to and partly around the body, giving them a tutulat form. Many of the larve feed npon grass and elover. while some devonr the leaves of the grape, and one interesting but very destrutive suecies infests the comb of the loney-bee often loming all the comb in a hive.

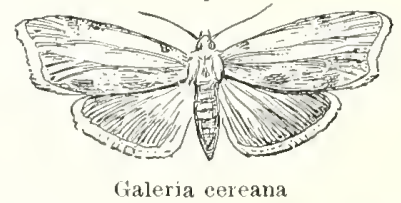

This species, Cateria repecme, is gray and purplish-brown in color, and the larvie pulates anong the loney-combs, where it has constructer its silken galleries. This inseet is domble brooded.

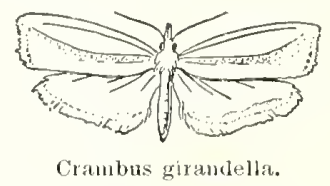

Crombus girmolnd is satin white with a lnoar gold hand on the fore wing's. 'The latran is whitish or gray, of a silky appearance and feeds 11 pon grass or elover. 'This insect is sometimes very abmutant, and I have seen the whole front of a honse where a bright light was kept huming duning the night so covered with this species as to look silvery white at a distanee of a few feet. 


\section{GEOMETRIDA.}

\section{Lorpers or spemners.}

The insects belonging to this group are easily distinguished by their slim bodies and broad thin wings. which, when the insects are at rest, are spread out flat, scareely overlapping at the edges. The coloring is usually soft and delicate in tone, being often hrown, graygreen or buff, crossed by darker wary lines. The antenne are often feathery (pectinated) and the legs usually stim and long.

The larve, from which the group derives the name of Geometridce, or "earth measures," are readily distinguished from the larve

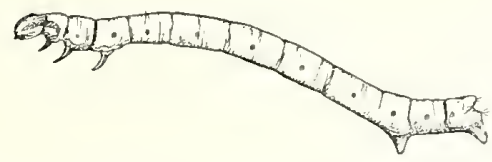

of all other moths by their peculiar mode of progression, which is by bending the body into looss, thus giving the alpearance of measuring the ground over which they travel.
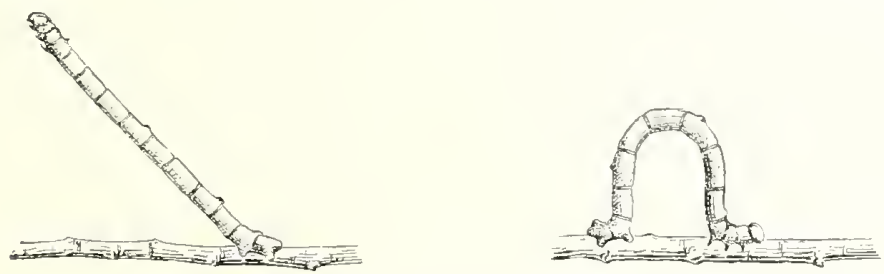

Larve of geometrial moths.

From four to six of the abrominal legs possessed by the larve of most lepidoptera are wanting in this group, in eonsequence of which the larre of geometrids may be recognized at a glance. Many of these larve spin silken threads wherever they go and are ready to quit their hold and drop from the leaves on which they may be feeding whenever danger threatens, mounting their threads and resuming operations again when it is past. Some of the caterpillan's spin slight cocoons beneath leaves at the trunks of trees, while others burrow into the ground and there undergo their transformations.

The insects of this group are numerous both in speeies and individuals, and specimens may be taken from the first wam days in spring till late into the fall. 
Angerone reoseterite is a yellow moth with light brown markings, and pxpands from an inclu and a half to two inches. The larva feeds

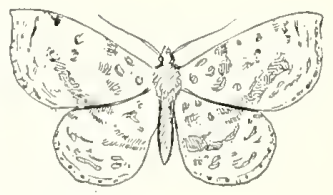

Ingerona crocataria.

on the currant and stawherry and is yellowish or light green, with brown dots and markings. The perfeet fly may be found among low hushes near cultivated fields during oune, and, like many other moths of this class, it flies a good deal in the daytime.

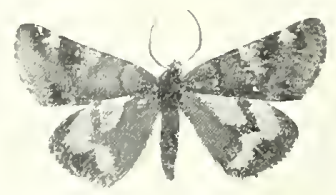

biepluos infaus.

Birphes infous is one of the first moths to appear in the spring and is a northern species, heing found throughout New England and north into Labrador. It is a rlay flyer, and may be taken in the latter part of Mareh or the early part of $\Lambda_{\text {pril }}$ before the snow has left the gromul. It prefers low, bushy distriets, where alders and willows abound, and in favorable localities may be seen in some abundance though generally shy. It is a pretty moth, about one and a quarter inches in expranse, the fore wings heing brown with light gray makings, while the lower wings are red with brown margins. The atreplilar in unlinown to me.

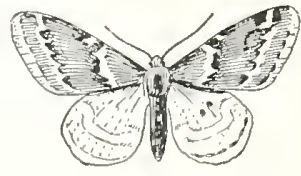

Anisolteryx veruata.

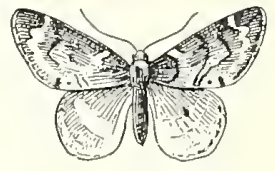

Anisopteryx autumnata.

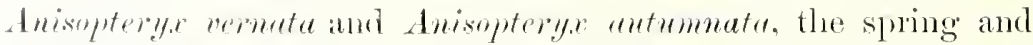
fall canker-worm moths, have in the larval state long been a seri- 
ous pest in different parts of the comtry, as they frequently appear in such numbers as to completely strip the foliage from apple, elm and other trees, leaving them as if devastated by a conflagration. 'These moths are about one and a quarter inches in expanse of wing.

As the females of these two species of moths are wingless grublike creatures, and can only deposit their eggs on the trees which form the food of the larve by climbing their trunks, it would seem that their destruction is a simple matter. Still one sees whole districts whercin fruit and shade trees have been stripped of their foliage, in spite of the precaution of encireling the trunks with bands of tar paper smeared with tar or printer's ink. The suring canker-worm

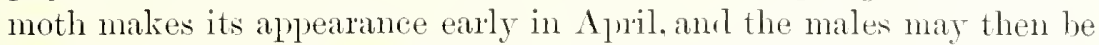
seen in numbers fluttering against the windows of a well-lighted room. By going out with a lantem the females may be found ascending the trees to lay their eggs, the males hovering about.

The moth of the fall canker-worm energes from its cocom, which is spun beneath the ground, late in October. 'The spring cankerworm makes no cocoon, but hollows out an oval cavity in the soil in which it passes the winter as a chrysalis. These two species resemble one another closely. looth in the larval state and as the perfect fly, the fully developed insects being light gray and hrown with light lower wings.

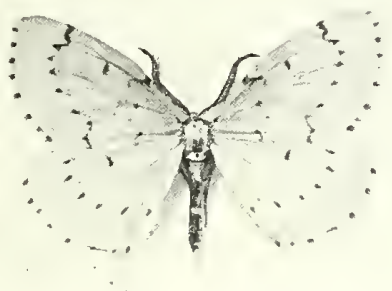

Zerene catenaria.

Zerene catenaria, beantifully white, with black markings and dots, is not uncommon in our fields and among low shruls in September and October. It is feeble in flight, and is often quite local. In expanse it will measure about one and a half inches. I have never seen the larva, but have fomd the thin, transparent cocoons attached to low shrubs, and have hatehed the moths. 
The larva of Amphillesis commetaria feeds on the maple and eurlant, ant. like the full-grown moth, is thick-bonlied for a geometrid.

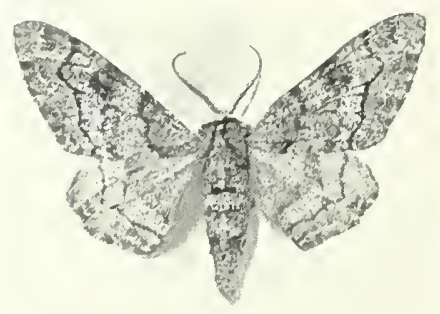

Amplidasis eognataria.

The moth is dark gray, speckled and marked with black, and about two inehes in expanse.

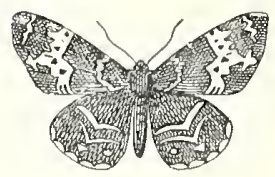

Rhemajtera hastata.

Rhemeptere hustuta is a black-and-white moth, little more than an inch in expanse, easily recognized from the other speeies of this class. It may be found in June along roads in the woods, where it flics in the daytime, much like a butterfly. This insect is said to be widely distributed, being found in Europe and Asia, as well as America. The eaterpillar, which is rark brown, feeds on the leaves of the birch, where it lives in colonies.

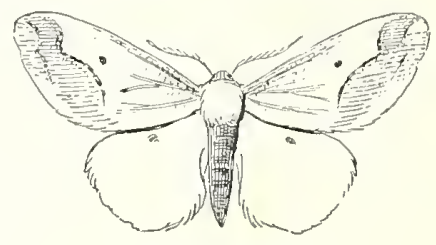

Hybernia tiliaria.

This moth, Hybernia tiliuri, abont two inches in expanse, resembles the canker-worm moth, in that the female is wingless and that it is in the larval state destructive to fruit and shade trees. The larvæ are yellow, with black lines on the baek and sides, and are sometimes so plentiful as to completely denude trees of their foliage. When 
fully grown the larva descend into the ground, where they trans. form to pupe a few inches below the surface. The perfect insect makes its appearance in October. It is light buff-yellow with orange spots, while the hind wings are nearly white.

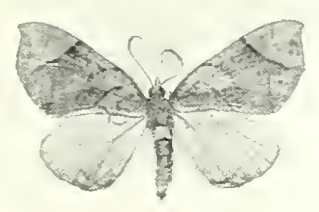

Petrophora diversilneata.

Petrophora diversitneate is a very pretty moth, which often makes its way into our rooms at night. It is yellowisls, with a slightly red or pink shade on the outer half of the fore wings; which are crossed by a number of reddish-brown lines. The lower wings are lighter near the body with a few brown lines near the lower edge. It is about an inch and a half in expanse of wings. The larva lives on the leaves of the grape, but rarely in such numbers as to do much damage.

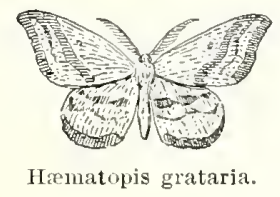

During August the pretty little moth, Humatopis grataria, may be found in meadows, especially near streams, where it is sometimes quite abundant. It has a wide range, as I have taken it in Iowa, Ohio, Virginia, and the New England States. The moth is about one inch in expanse. It flies a good deal in the daytime, soon alighting after it has been flushed from the grass. Its colors are yellowish-red crossed by bands of pink. The larva is said to feed on chickweed.

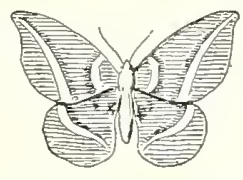

Geometra iridaria.

An exceedingly beautiful little moth is Geometra iridara. About one and a quarter inches in expanse of wings, it is of a rich 
shade of green, the wings being crossed by white lines edged with purple. There are a number of green moths belonging to this group which resemble one another closely, but this is the most attractive in coloring, and were it as large would rival the beautiful Actirs lume. I know nothing of the life history of this moth, but lave often been charmed with its bcauty as it flew in at the open window to my lamp.

Among the many geometrids to be found in our country I may mention the following speeies, as shown in the illustration.

Endropice meryinute, having all wings yellowish-buff, bordered with a broad band of light brown. Expanse one and three-quarters inches. 'This moth may be taken with a lamp early in September. A smaller moth, Endropice hypoctererie, has brownish-gray wings with brown markings. It expands about one and a half inehes.

In Eutrepela clemeterte we have a moth with brownish-gray wings the inner part dirrker crossed by brown and light gray lines. It exprands one and thrce-quarters inehes. Entrapela transversata is light brownish-yellow, with distinct lines and markings of brown. Expanse nearly two inches.

Acidalin emmedente is ereany-white with brown markings near outer erlge of wings. Expands one and a quarter inches.

A finely marked moth, Therina seminederia is light gray with wings crossed by yellowish-brown and yellow lines. Expands one and three-quarter's inches.

Before leaving this interesting elass of inscets, having figured and described only a small number of the more common species, a few words in regard to the wonderful protective coloring, shapes and habits of some of these moths and their larve may prove interesting to the student of entomology. The thin, flat wings of these moths cnable them to conceal themselves, not by folding the wings up close to the hody as so many other species do, but by spreading them out flat on the objects on which they rest, hugging so closely to their support as to appear to be a part of it. Some of the species closely resemble patches of lichens when flattened against the trunks of trees, the lines and bits of color on their wings helping out the resemblance to such an extent that when discovered, one is sometimes half in doubt where the insect leaves off and the bark begins. The green slecies, many of them, extend their wings on the green leaves, lying so close to the surface as to be scarcely distinguishable. 

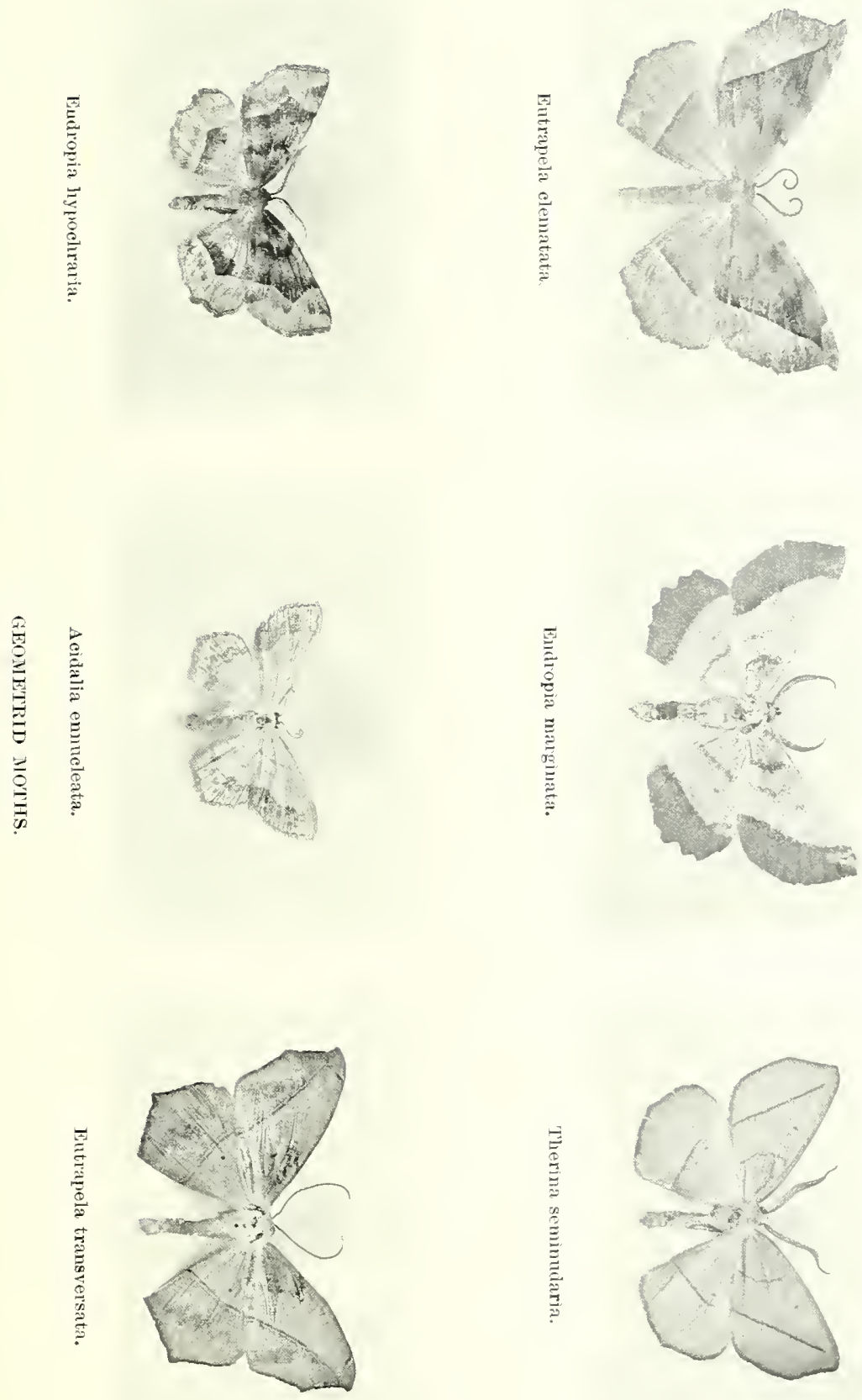

Some yellow and brown species have the habit of resting with wings extender on the upper sides of leaves so as to almost exactly resemble the brown and withered patehes on half-clead foliage. One or two kinds when at rest throw their bodies into curious attitudes, at the same time bending their wings into such shapes that when seen one can hardly believe they are anything but dead fragments of leaves athering to stems.

The larva of this group of insects are many of them protected both by their shape and coloring, and even by their habits in a remarkable degree. A large number closely resemble twigs, and will remain standing out straight at an angle of forty-five degrees from a branch, holding on by their posterior claspers for hours at a time. So closely do these caterpillars resemble the small stems of plants with their minute knots that one may have to pick them from the branch to he sure he is not mistaken.

One does not need to go far flom home to come acloss examples of protective mimicry as striking and as useful to contemplate as any the world affords, and a study of the geometrids in both their larval and mature state will point as clearly to the law by which every animal is just adapted to its surroundings and protected in a degree from its enemies as any so charmingly used by the great naturalists Charles Darwin and Alfred Wallace to illustrate the law of natural selection.

\section{NOCTUIDA.}

$$
\text { Oerlets, or Moth Millers. }
$$

The moths belonging to this large gromp are stout-bodied and rapid-flying insects, and are, as their name implies, seldom seen on the wing except at night. When at rest they fold their wings over the body, roof-shaped, in such a way that the lower wings are entirely concealed. Their antenne are long and tapering, and their wings are always fastened together by the loop and spur already mentioned in another chapter. Most of these insects are sombre in coloring, browns and grays being the predominating colors. Many of them are thickly covered with long hair-like seales, which are easily loosened. The thorax is frequently tufted: and the legs covered with long scales are sometimes provided with spines at the joints. Most of our native species are of small or moderate size, but some of the 
exotic speries are gigantice, specimens of Erelus strex from Brazil sometines meaturing twelve inches from tip to tip of the expanded willgs.

Great difficulty is experienced in jelentifying many of the small and plain-colored insects belonging to this group, as they are frequently very much alike both in shape and markings, and puzzling valuetics in colors atre common.

'The latrot ale usually smooth, thomgh some are hairy, and a few possess tubereles and wats. They are generally provided with sixteen legss. Some make coeorns in which to transform to the ehrysilis state: the majority horrow into the gromel and form smooth, nalien ehrysalintes. Many of the caterpillars feed exclusively by night, hiding by day, and a number of species are among the principal insect pests with which the gardener and famer have to cleal.

Onr first example is the splemdid moth Erelus odora, which exphuts six or seven inches and is occasionally taken as far north as Canala. It is a rane visitor and one may consider himself cxceedingly fortunate who anptures a good specimen, for it is said not to live in the United states except as a wanderer from Mexico. I have never taken a specinen, but know of several instances where they have been captured in New England and the Western States. The insect is not rare in Mexico: and one rarely sees a collection from that comntry which does not contain one or more speeimens of this fine motl.

The predominating eolor is dark hrown; but in certain lights, jink and metallic purple and blue are reflected from the wings.

There is frequently a good deal of variation in this species, sometimes the wavy lines rmming across the wings being almost white and again obseure gray or yellowish brown. 'This insect is a very strong flyer, as specimens are said to have been taken on board a ship, one humdred and twenty-five miles from the nearest land. I know nothing of the larra or of the life history of the insect.

In Parthenos mbilis, the insect looks very much like the Catocala and has much the same hahits. The upper wings are clark brown, black, gray and creamy-white. Thorax and borly light brown. lower wings blackish-brown with four wavy and somewhat indistinct hands of yellowish-onange. Expanse of wings two and one-half inclies. I have slecimens of this inseet from New England and the Mirlde and Westem States. It may be taken in the company of Cotorald and seems to have a wide range. 


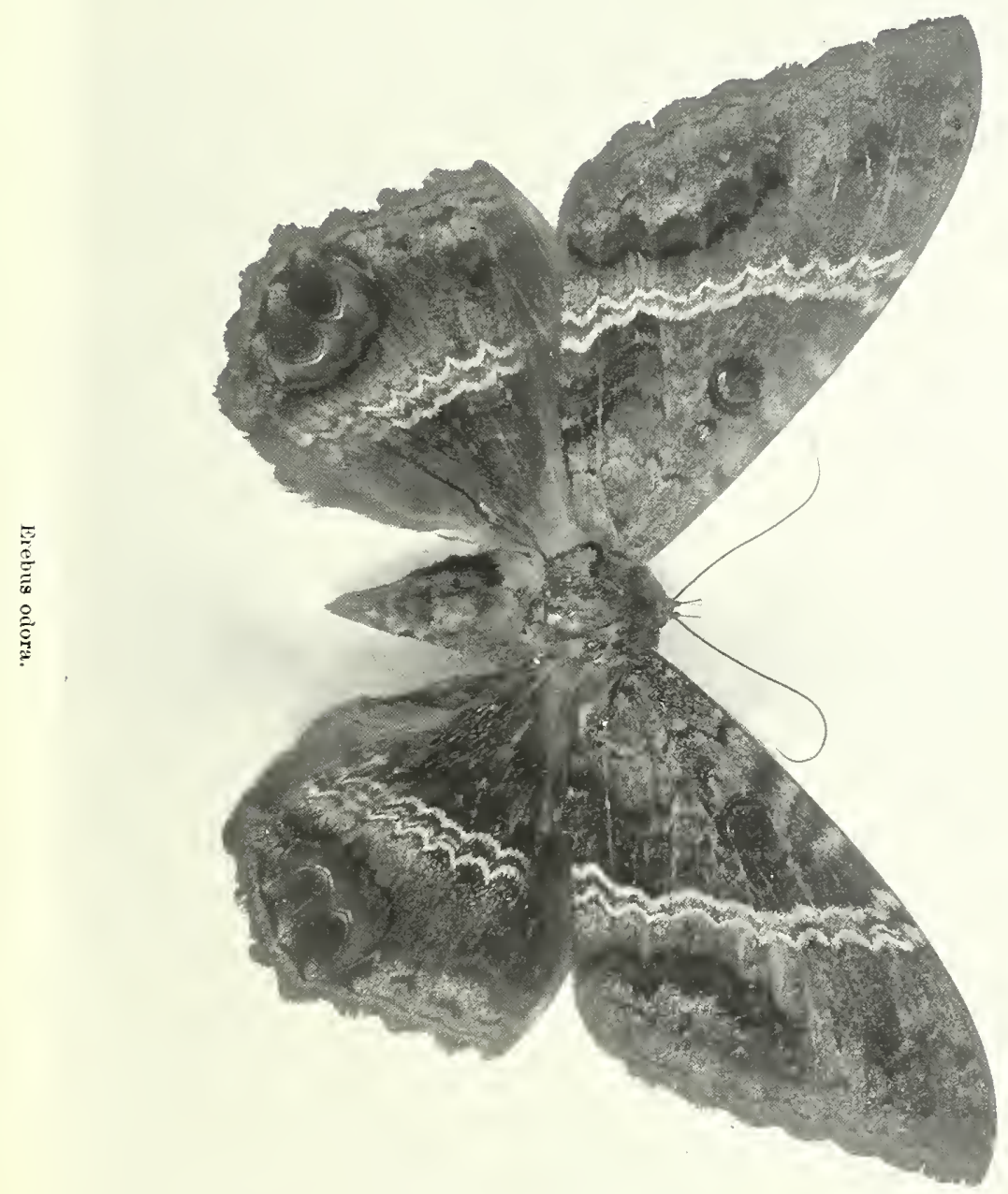



The genus Catocald is very well represented in this country and is of more interest to the collector than any other class of the Noctuide, both on account of the large size of many of the suecies and also for their great beauty. These insects frequently measure three inclies or more across the expanderl wings. 'Tle upper wings are usually brown or gray with mumerous zigzag lines rmning across them, while the lower wings are frequently crossed with broad black bars, alternating with bands of red, yellow or white. The lower wings are hidden from view when the moths are at rest. The larve feed on various forest trees, oak and hickory being their most common food plant. Both the larva and the perfeet motlis are protected by their resemblance in eolor to the bark of trees, and only careful and dilligent search will enable one to find them. There are eighty or more species of this genus native to this country, and a large number of valieties which have been griven separate names. 'The identification of some of the suecies is difficult, both on aceount of their variation and the obsemity of their matsings.

Cretorate crere is one of the most common moths of this genus as well as one of the largest and finest.

It loves to fly along water-eourses at night. partieularly where they are bortered on either sirle with forests, and on this aceount may often be found in the daytime hirling on the underside of the boards and beams of hidges, and I have myself taken thilty-seren specimens of this fine moth under one bridge in less than an hour. If one knows of such a place, he may visit it every day from the midille of Angust to the last of September and be tolerably certain of finding specimens of this and sometimes one or two other species. Where trees overhang the water, too. one may look for this insect with good clances of success in fincling it.

The larva of this insect lives on willow and may sometimes be found descending the trunk of a tree preparatory to burowing under the leaves to undergo its transformations. The seales of all these moths seen to be very loosely attacher, and the greatest care is necessary in handling them. I make it a rule never to tomch one with ny fingers for fear of injuring it. When a moth of this rind is seen on the trunk of a tree do not try to use the net for its capture but place the open end of the poison jar over it and when it flies into the trap put on the corer and the insect is safe. Each specimen should be taken out and placed in an envelope or collecting paper before another one is put into the jar. Although many of the cito- 
mell may be entived into one s room on warm evenings in August, by placing a light in the window, I lave never yet taken Catocala ande in this 1manner: nor does it seem to be attracterl by sugaring. and if one had to depend on this mode of capture he would conchude that it was a rare insect.

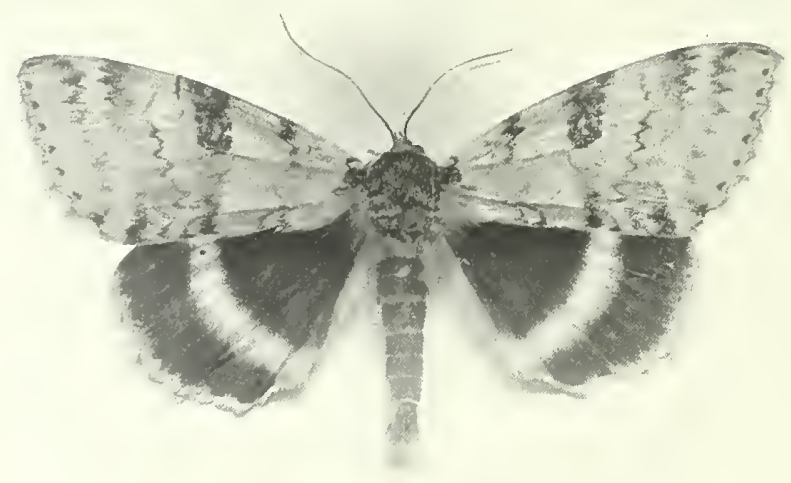

Catocala relieta.

This is one of the finest and larest of the catoende. The upper wings of the male insect are creamy-white, crossed ly several indistinet bands of gray; the lower wings are black, with a white curved lar crossing just below the midtle and a creamy-ivlite fringe at the matrin. The heal is light: lout the thorax and aluhmen are dark gray, almost hack. The "uper wings of the fenale are much tarker, although specinens may be found ranging from almost pure white to clark gray. A fine specimen of this rare moth will measure nearly four inches acrosis its expanded wings, and it is enough to make one's lieart jump, with excitement to see one of these strikingly marked insects quietly sipping the intoxicating liquid where one has smeared a tree-trunk with rum and molasses.

Like many other species of the genns Catorala, this insect is local, and may sometimes be found in some ahundance. One collector with whom I an acquainted has taken a dozen perfect specimens in a season, but this must he considered very musual. I lave always found it a very scarce insect. It is widely distributed, as I 

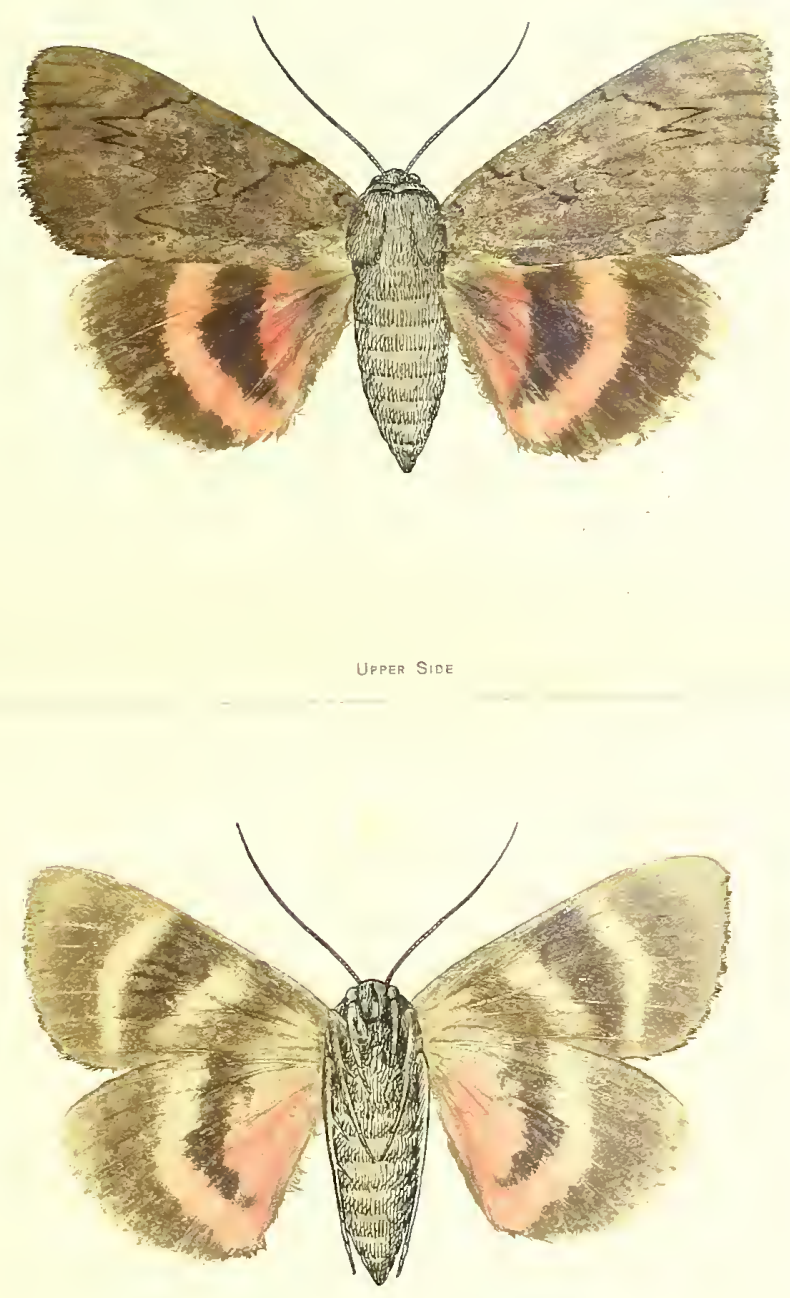

have hat specimens from New Englanel, Ohio, Illimois, Artiansas and vilginia.

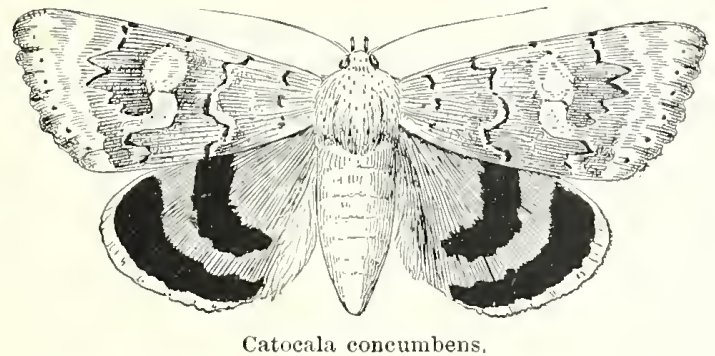

Although eommon, Catocula conrumbens is a vely attractive insect. Its forward wings being a soft gray, while two bars of black and two of pink adorn the lower' wings. 'This moth nay be taken by sugaring, and it will also eome to a light, and is a pretty creature for one to see coming in at his window flutteling its wings of black and pink just in front of his face. This inseet is probably found over a large part of this eountry, as I have specimens from many localities. Stone walls or heaps of rocks in the wools seem to be favorite hatunts of this moth: and as the bright pink lower wings are eovered by the gray upler ones when at rest, it is not easily discovered. Two and three-quarters inches is the expanse of wing of a goodsized speeimen. 'The caterpillar lives on willow.

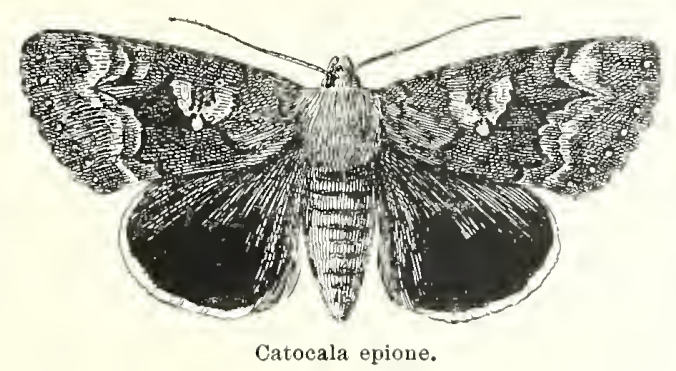

A number of the Cotocald have no bands of bright color on the lower wings, but these members are simply black or tark brown with a white fringe, while the upper wings are very like those insects I have been deseribing. The present speeies is one of this class, and there are a large number so closely related what their separation into speeies is not an easy matter'. 
These moth inhabit oak wooks, generally in company with other kinds, and are most often to be found in the daytime hugging closely to the trmess of the trees where their gray wings marbled with dark hrown and black render them diffeult to see. When once alarmed they readily take to flight and are strong and rapid on the wing. This species may be taken by sugaring but rarely comes to a light. The latrva lives on oak.

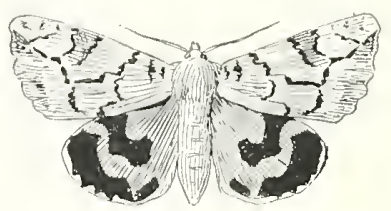

Catocala fratercula.

The little Catorala froterula, which much resembles some of the larger kinds, is often abundant in oak woods in August, where it may be fomd in company with the larger species. Its fore wings are light gray, with creamy-white and brown patehes and markings, and its lower whing are onange banded with black. One will often find this moth on fences and stone walls as well as tree-trunks. Ialf-a-dozen ol more speeies of the same size may easily be mistaken for this and the beginner will encounter many difficulties in separating the species of Catocala. The larva lives on oals.

The moth Catoctla croggama has ulper wings gray and brown, with hlack malkings. 'Thomax gray. Body brown. Lower wings brown near the body, the rest being black crossed by a single narrow hand of dull orange, edged with yellowish-gray. This inseet expands a trifle over three inches. I have not found it a eommon specie, but have specinems from Arkansas, Ohio, Massachusetts and ()ntario, Camarla.

In Catocela prete the upper wings are gray, light brown and black. Thodax gray and black, hody light brownish-buff. Lower wings orange-red with one nar'ow and one broad black band, the outer margin yellowisl-gray. The insect expunds three inehes and a lralf in a tine specimen. This is not a rare insect, and I have taken it in Massachusetts, Southern Ohio and Illinois, and have speemens from Ontario, Canada.

Catomble subute. Ulper wings gray and light brown. Thorax light gray, holy yellowish-brown. Inwer wings oehreous-yellow 

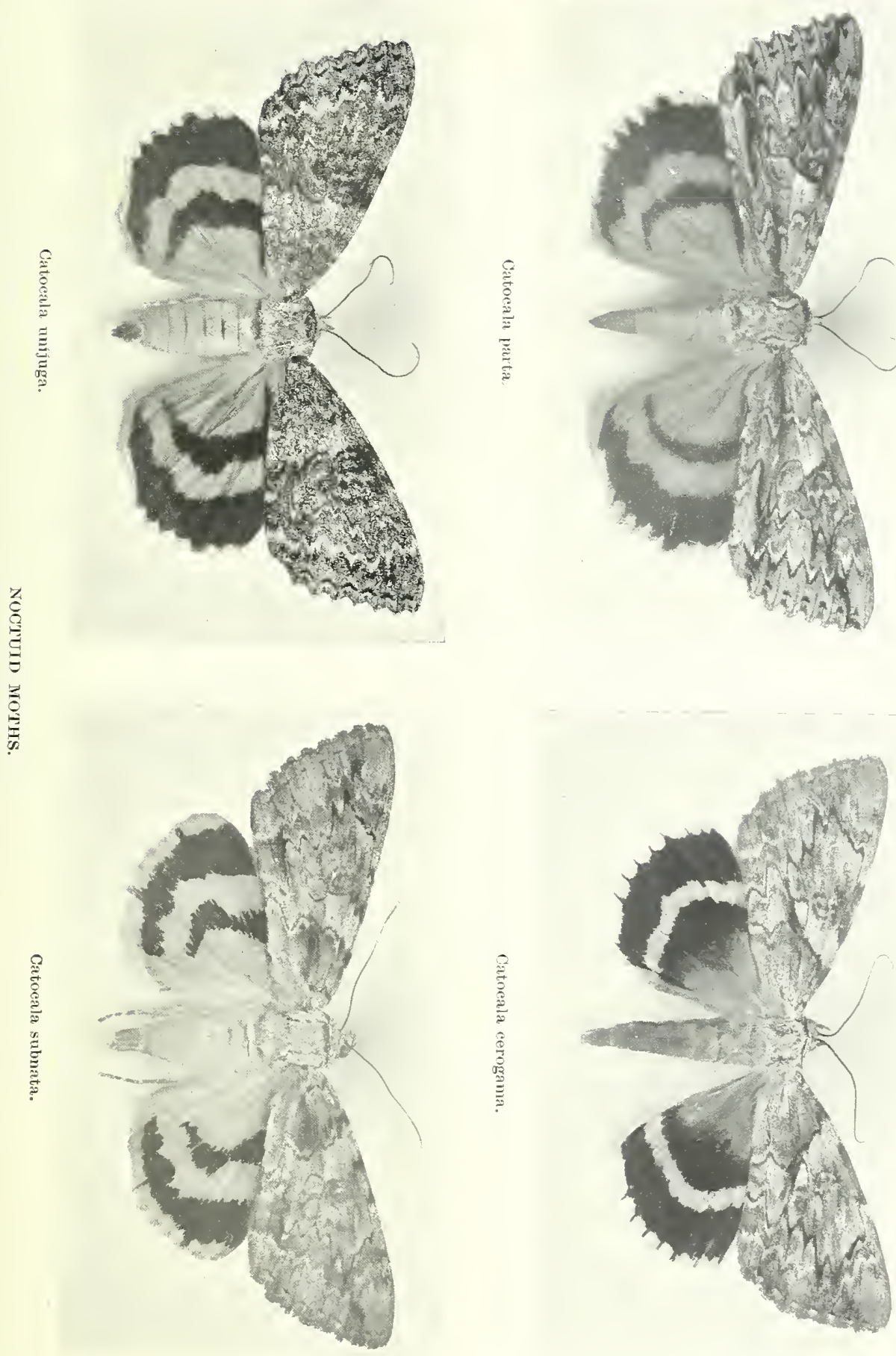

crossed by two bands of black. Expanse ncarly three and one-half inches. I have never taken this insect, but have specinens collected in Southern Ohio.

Catocela unijuga. Upper wings dark gray and black with light gray wavy lines. Thorax dark gray. Body brown. Lower wings bright orange-red, edged with white and crosserl by two intensely black hands. Expanse of wings three inches. 'This is a common insect in the northeastern part of the country, and I have a number of specimens from Canada.

The species, Catocald immlens, is a very variable one. The upper wings are usually dark brown, light brown and black. Thorax and body light brown. Lower wings reddisll-orange edged with yellow and crossed by two bands of black. This insect expands two and one-half inches and is sometimes found in numbers on oak-trees. I have specimens from Iowa, Ohio, Massachusetts and Ontario.

Catocala flebitis. Upper wings dark gray and sooty black. Thorax dark gray. Body sooty brown. Lower wings black, edged with yellowish-white. Expanse two and a quarter inches. 1 common insect in oak woods in September and Octolsel.

Catocala desperata. Upper wings light gray and light brown and crossed by black lines. Thorax light gray. Body sooty brown. Lower wings blackish-brown, lighter near the body and edged with yellowish-white. Expanse two and three-quarters inches. Not a rare insect in New England and the Middle and Western States.

Catocala palcogama. Upper wings gray with black makings. Thorax gray. Body light brown. Lower wings orange crossed by two black bands. Expands two and one-half inches. I have specimens of this insect from Southern Ohio, but have never taken it in Massachusetts.

Catocala amica. Upper wings gray and black with a greenish shade. Thorax gray. Body yellowish-brown. Lower wings orange with a large brownish-black pateh. Expanse of wings one and threequarters inches. This insect is sometimes very common in autumn, and may frequently be taken in numbers on the trunks of poplartrees. I have also found it abundantly when collecting other Catocala in oak forests.

Catocala antinympha. Upper wings blackish-brown, with blaek and brown marks. 'Thorax and body dark. Lower wings orange, with two black bands. Expanse, two inches. I have specimens of this insect from Ohio and Massachusetts. 
Pouphila quentrificris is a little moth which expands about an inch. It is very dark hown, or alumst bauk, lighter toward the

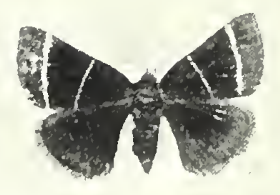

Poaphila quadritilaris.

edges of the wings. The fore wings are crossed by two white stripes, the inner one being the narrower, while the lower wings are plain dark brown. This little insect inhabits marshy mealows and when disturberl tlies so rapidly that it is difficult to follow it with the eye. Its flight is short, and it alights suddenly on a grass blade, keeping an eye on the intruder and holding itself ready for another flight. I have taken this moth melely with a lighted lamp in Massachusetts.

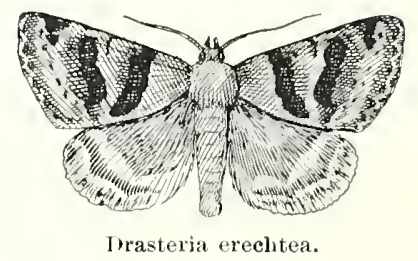

Dirsterin erechten is a very common inseet frequenting open grassy fields and meadows. It flies rapidly when disturbed, but only for a short distance. 'This moth is one of the first to make its appearance in the spring, and may also be found abundantly in the late summer and autumn. In expanse about an inch and a half, it is one of the commonest visitors to the colleetor's lamp, sometimes becoming a great nuisanee, fluttering about the lamp and even into the chimney, extinguishing the flame.

The larve of this moth feeds on clover and is of a reddish-brown color with darker stripes and two light gray lines on the baek. The eaterpillar might easily be mistaken for a Geometrid as it has but three pairs of abdominal legs and moves with a looping notion. The mature insect is grayish-brown with dark brown bands and markings disposed as shown in the illustration. The male is more 

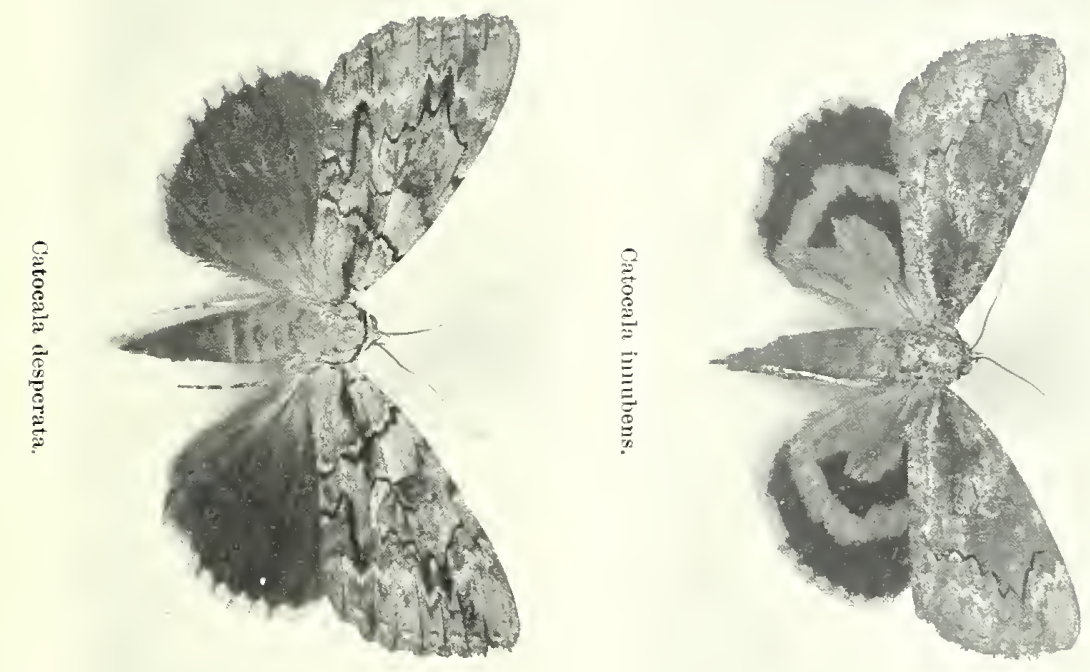

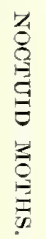
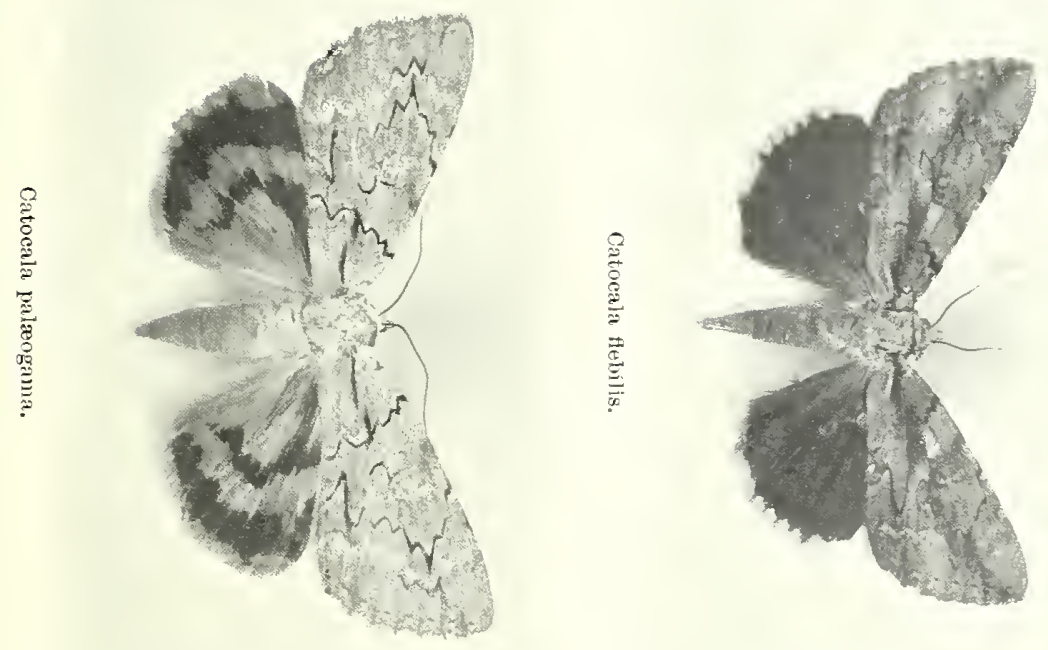

strongly marked than the female. This insect is found over a large part of the American continent.

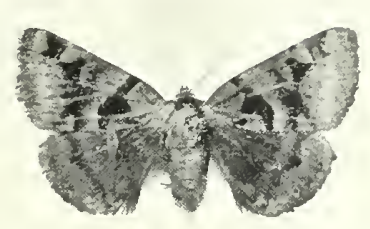

Euclidia cuspidea.

A pretty species related to the preceding is Eudidia cuspidea. Of the sane size, its wings are brown crossed by bands of light yellowish and reddish-brown and having on the upjer wings several patches of very dark velvety brown or black. This insect may occasionally be seen among low bushes and shrubs, particularly about patches of sweet fern. When disturbed it flies rapidly for a short distance and drops suddenly among the low bushes and conceals itself. The larva is unknown to me.

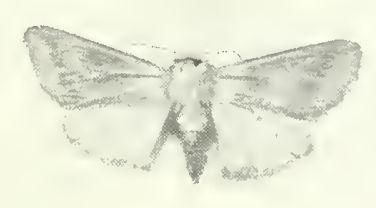

Rliodophora floxida.

One of our most beautiful Noctuids is Rhodophore floride. Its expanse of wing is about an inch and a quarter. The fore wings are mottled with rich pink on a rellow ground for two-thirds of their length, the outer margin being yellow, while the lower wings are very light yellow or almost white. This insect may often be seen about the evening primrose, which is the food plant of the caterpillar, and it has the liabit of conccaling itself among the flower petals in the daytime, the tips of the wings alone being visible. This little moth has a wide range, and I have taken it in California, Nevada. Arkansas, Virginia, Ohio and in Massachusetts, and have specimens which were taken in Canarla and Florida. The larva is probably a 
noctumal feeder, as it may be found hiding in the daytime among the yomng leaves of the primrose. It is greenish-yellow in eolor.

'The eotton worn, Aletin agillacen, and the army worm, Hellophila mnipuncta, both belong to this group of insects, and are well known where they ocour in numbers on account of their destructiveness.

'The former lives on the leaves of the cotton plant, as its common name implies, and is the greatest enemy the cotton-growing industry lats in the Sonth. This eaterpillar is nearly two inehes long when lully grown, and is green in eolor with blaek stripes and blaek and yellow spots. The moth, whieh is very plain, expands an ineh and a lialf, and is brownish-glaty, the fore wings being erossed by faint wavy lines of a darker color. 'This inseet is found mostly in the cotton-growing States, but has been taken in the North, where its occurrence is said to be from southem migration.

The army worm has a wider distribution than the eotton worm, being found over the whole of the eastern lialf of the country as well as in Europe and Australia. The moth is plain in eolor, being yellowish-gray and hrown with a white lot in the eentre of eaeh fore wing. These eaterpillars feed on grasses, and are sometimes so

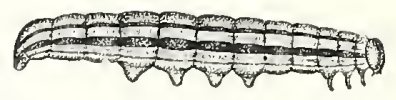

Larva of Hellophila unipuneta.

abumlant as to devour almost every vegetable growth within their reach. At such times they commence their march for "pastures new," and are often seen in great numbers and all marehing in one direction, which gives them their eommon name. 'The caterpillar is striped with dark gray or dark brown on a greenish-yellow or grayish-yellow ground, and is an ineh and a half long when fully grown. The pupa state is passed in the gromel.

$\Lambda$ genus of Noctwido having many Ameriean representatives, among which are some very beantiful species, is Plusia. The fore wings rather pointed, usmally of different shades of brown, are frequently ornamented with a silvery or golden comma-shaped spot (in some species severil spots and patches), while the thorax and upper. part of the abdomen is adoned with tufts of hair-like seales. The larve, generally greenish in color, sometimes striped, are some of them injurious to garden vegetables, and spin their thin eoeoons, thromgh which the pupe ean be seen, among the leaves. 
These moths frequent flowers in the evening, one of their fitvorites being the phlox, upon the blossoms of which they alight. It is amusing to wateh one of these moths standing almost upon its hear

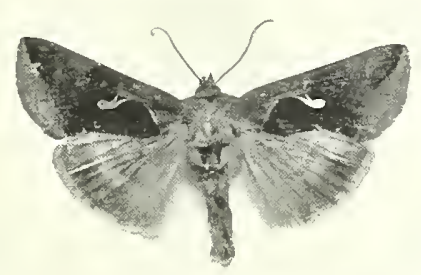

Piusia simplex.

as it thrusts its tongue into the flowers in its eagerness to proenre the sweets. Plusid simplex is a common and well-known insect, expanding an incls and a quarter or more. The fore wings are brown, in some specimens pinkish-brown, darker near the centre, where there is a silvery spot whose shape cau be seen in the illustration. The lower wings are dull yellow and matgined with a hroad band of brown. This insect is probalnly donble-hooded, as I lave taken it in June and again in september.

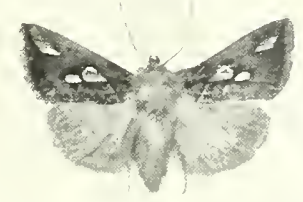

Plusia putnami.

A very pleasingly colored species is Phusid putmomi. The head, forward part of the tholax, antenne and legs are reddish-pink, the tuft of hairs on the thorax being pinkish-brown. The abdomen is yellow with tufts of pink hains on the sides. The fore wings are reddish-brown, deeper toward the outer margins, and ardorned with patches of silver and golden colored scales. The lower wings are yellowish with a graysh band near the margins, and edged with pink, the whole making one of our most beantiful little moths. I have never found this slecies common, but lave taken it with a 
lamp in Olio and Massachusetts in Angust. Some species of Plusia have no metallic spots but are rich in their reddish-brown shadings.

In Plusin were the upper wings are purplish-brown. Head and forward part of thorax yellowish, dark gray above. Body yellowishgray. Lower wings dark brown, lighter next to body. Expanse one and one-laslf inches.

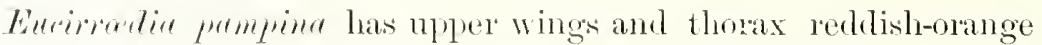
with hown markings. Lower wings and body pinkish-gray. Expanse of wings one and one-lualf inches. This is a eommon little moth in antumn, and is often taken while sugaring for Catocald.

In the species of the genus Gortynu the larve are stalle-horers, living in the stallis of both wild and cultivated plants, and sometimes doing considerable danage to the potato, tomato, Indian corn, ete... cansing the plants to wither and die.

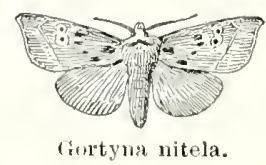

In Gortynu nitrle the fore wings ane proplish-graty stippled with yellow, a light line rmung across them. The lower wings are light brown. The larva is pinkish-brown, darker toward the head and is marked with light gellowish-white stripes. This species is fre"puently destructive to the dahlia and aster. passing its larval state within the stems of these plants and devouring their substance. The inseet pupates jnst below the surface of the ground, where it construtets a slight cocoon. The moth appears in September.

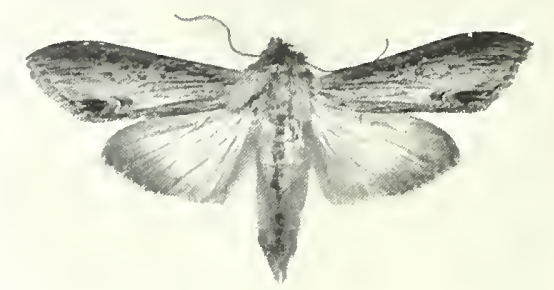

Cueullia speyeri.

Curullit speyeri is a gray moth with slender pointed upper wings marked with brown, the lower wings being white, margined with 
gray-brown. This insect has a crest on the forward part of the thorax, and from this fact is called the hooded owlet. The caterpillar feeds on golden rod.

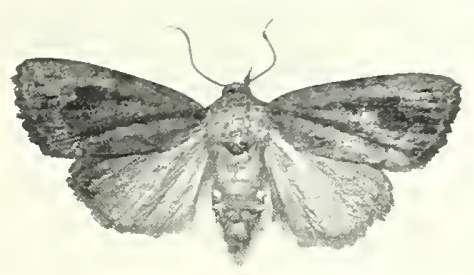

Pyrophila pyranidoides.

Pyrophita pyramidoides is a common moth with brown fore wings crossed by wavy lines of dark brown and black, while the hind wings are copper colored and brown. The whole upper surface of the insect is very glossy. In september this insect may be found on fences and tree-trunks and I have sometimes dislodgerl a number of them when stripping the loosened bark from dead tree-trunks in search of beetles. The food plants of the larva are the grape and Virginia creeper.

A very interesting species in the larval state is Bellura gortymides, which lives in the leaf stems of the pond lily, haring a communication with the air through a hole in the leaf. When feeding it descends below the surface of the water to a distance, according to Comstock, of two feet or more. The perfect insect is brownish, and expands an inch and a half.

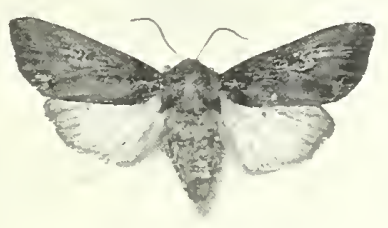

Hanestra picta.

A beautifully marked insect in the caterpillar state is Mumestra picta and the larva goes by the appropriate name of the zebra worm. 
This insect is frequently to be seen in the antumn on the leaves of the parsilip, carrot and cablage, althongh I have never seen it abundant enomgh to do much hamm. The smowth, naked eaterpillar is

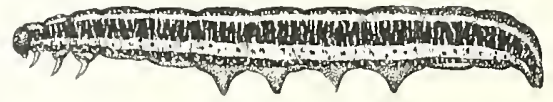

Larva of Mamestra picta.

striped longitndinally with yellow and black in conspienous bands, these stripes being crossed with numerons fine white lines on the sides of the inseet. The larva burrows into the ground and passes the winter in the pupa state, whence it emerges in the spring a moth with dark chestnut-hown fore wings and yellowish-white hind wings. The moth expands an ineh and a half.

In the genus Agpotis the larvare are known by the alproputiate name of cut-worms. The raviges of these gests are well known to farmers, gardencess and florists. What an aggravation it is after purchasing aud carefully planting a few choice pansies or sowing and diligently caring for a berl of sweet peas to see the young plants toppling over and withering in the morning smo, their stems cut off just above the roots. The egge of the moths are laid in the ground during only and Angust and the infant eaterpillars soon make their appearance. but are so minute while their fool (the roots of suceulent plants) is so abundint that their depredations are not noticed. As cold weather advances they hurwow deep into the gronnd, where they pass the winter in smooth oral eavities in the earth in a curted position. When warm weather again awakens them to life they work their way to the surface and are then most destructive to young plants. often cutting off in a single night numbers of cabloages, beans or peas, and hiding just helow the surface of the ground during the daytime, rearly to renew their depredations the next night. When the larve arrive at maturity they again descend into the ground, where they pupate. The moths emerge in July and Angust. The larrat are stout-bodied creatnres, dingy in color, often striped from head to tail with light gray and hown or black. 'They are nakerl. with a horny plate on the upper part of the borly near the hearl, and the different sprecies so rlosely resemble eath other as to be scarcely distinguishalile. These insects are very destronetive to many flowering plants as well as garden vegetables, and one or two speeies have been known to aseend apple and pear trees and grape vines in 
the night and devour the frnit buds, greatly diminishing their proanction.

Many experiments have been tried to destroy these pests, but perhaps the most effectual is to carefully remove the soil from about the infected young plants and kill the caterpillars as they lie curled up near the roots an inch or less below the surface of the ground. Small tin basins or cups placed in the ground near the plants in such a manner that their tops are on a level with the surface will be found to be excellent traps for these annoying maraters. The caterpillars in their nightly wanderings in seareh of food fall into the receptacles and one may wreak vengeance on them in the momiug as they will be unable to climb up the smooth sides of the tin. Rerenge is indeed sweet when one has seen his finest flower's and regetables cut off in early routh by these destructive "worms." "The perfect insects are mostly nocturnal in their habits, coming into our houses at night and secreting themselves behind picture frames or among clothing in our elosets in the daytime. Some species are. however, day-flyers and may be seen during the sumny hours about the blossoms of the milkweed and golden-rod busily sipping their sweets.

Most of these moths are very dull in color. though a few are marked with pleasing tints of brown, gray and buff.

The following illustrations of a few typically marked species of Agrotis will give an irlea of their general appearance.

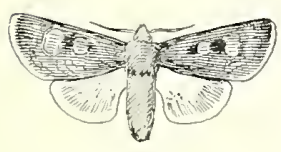

Agrotis tassellata.

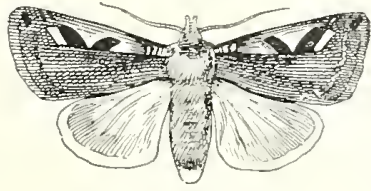

Agrotis e-nigram.

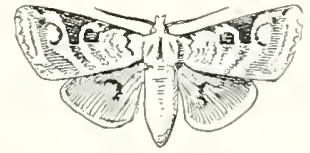

Agrotis normaniana.

Ayrotis tassellata is a small moth. The eolor of its fore wings is lark gray with two light spots and two black spots on each. The lower wings are light brownish-gray, darker at their edges. 'This moth expands one inch and a quarter.

Agrotis c-nigrom is a rather dark species, the fore wings being dark brown, gray and black, with a few lighter spots and markings, while the hind wings are light brown. It is one of the larger species, expanding an inch and three-quarters. 
Aypotis normanionu is a prettily matsed species, its fore wings being marked with gray, buff and black, with the hind wings buff and hrown. The insect expands an inch and a half.

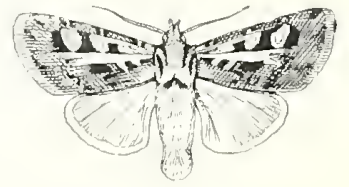

Agrotis letrilis.

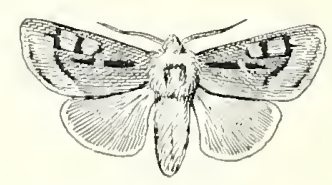

Agrotis venerabilis.

An expeedingly abundant species during Angust is Ayrotis herilis. 'The fore wings are gray and black, with cream-eolored marks and spots, while the hind wings are light brown. Expands about an inch and it half.

Atmotis renerditis is a reddish-thown moth, whose hind wings are grayish-bown. Expands an inch and threesighths.

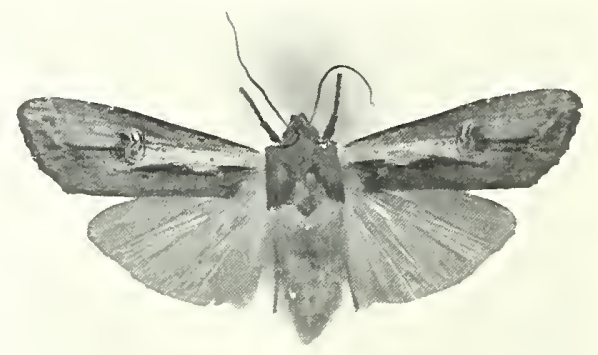

Calocanna nupera.

A rather rase noth, and at the same time a lnettily marked insect, is calocampa muperd. This insect expands two inehes and a half, and is marked as follows: the uprer half of the fore wings is gray, dartser toward the tips, light ash-gray nearest the borly; an intermpted biak line runs longitudinally through the middle of the wing, on which is situated a black spot; the lower half of the fore wing is ehestnut-hown: the lower wings are reddish-brown, with a glossy surface; the thorax is dark brownish-purple and the aldomen reddish-brown. I have taken this insect oeeasionally in autumn while sugaring trees for Catorald. The larva of this moth is miknown to me. 

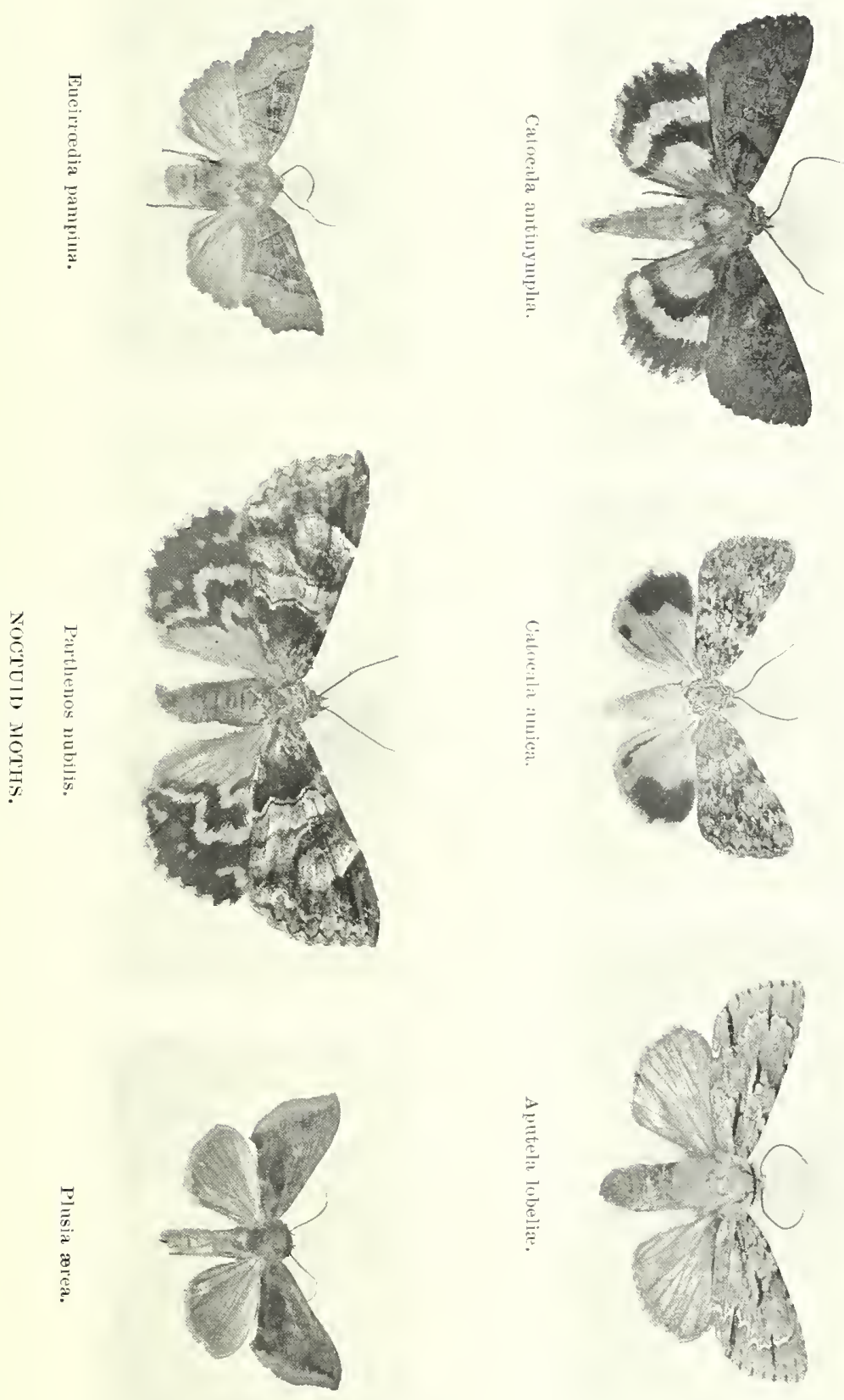

Apatela americame is a gray moth. witle a scalloped, light gray line near the outer margin of the fore wings edged externally with black and brown, and with a row of black rlots along the outer

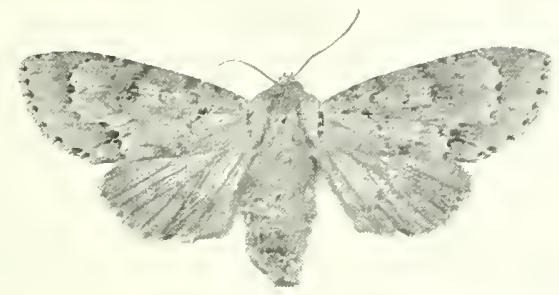

Apatela americana.

margin. The lower wings are yellowish-gray, and the insect expands two inches and a lialf. The lairy caterpillar feeds on the leaves of the maple, elm and chestnut, and is dsually seen partially wurled sidewise when not feerling. Its hearl, belly and legs are black, and its back is dull green. The hairs covering its body are yellow, with two pairs of tufts of long llack hairs on the forward part of the body and a single tuft near the posterior extremity. In autumn the insect spins a cocoon composed externally of silk and laims from its body, inside of which is another covering. composed of silk and bits of bark or chips of wood. This cocoon is usually hiden under the loosened bark of a tree and in it the pupa passes the winter.

In Apatela lobelice the upper wings are gray with light gray lines and black marks. Thorax gray. Abdomen brown. Lower wings light brown. Expanse two inches.

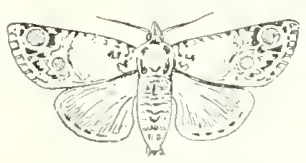

Gramatophora trisignata.

Gramatophore trisignute is a pretty species, being of a mouldygreen color on the fore wings, marked with lines and mottlings of black, with three round reddish-brown spots on each wing, the lower wings being light yellowish-brown.

This moth I have taken on one or two occasions with a lamp in Ohio and Massachusetts. I have also received one specimen from 
'Tounto, Oni. It expands an inch and a half. 'The las'va is one of thuse strunge, weind forms in which Nature seems oceasionally to delight, suggesting that she must have been in a "wondrous melry mool" in evolving a being so grotesque. The extreme of the

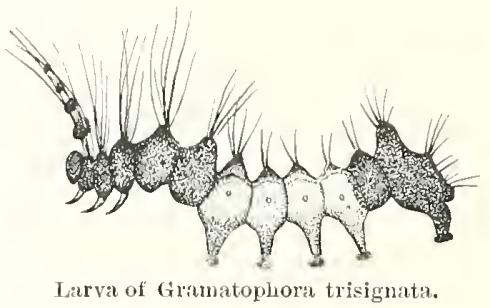

fantastic and the ridiculous seems to have been reached in shaping this ereature. (O) beauty it has none, and is withal a most venomous looking animal, for when disturbed it swings its load from side to sirle in a monuing manner. The tuft of hains just back of the head usually have attached the hard black shells of the insect's head which were shed in the earlier moults of the larva, and these add a good deal to its meanny appealance, giving one the inplession that it has neveral heads of different sizes. The caterpillar is dark brown, with a lighter hown patch oceupying several of the segments. The six front leges, head and wats from which the hairs spring are shining black. 'The foor plant of the eaterpillar is lilac.

\section{BOMBYCIDL.}

\section{Spimiers.}

The family of bombyx is one of great importance, as it not only includes many of the largest and finest inseets in the world, but also those of greatest inprortance to man from an economie standpoint, as in this family helong all the poincipal silk-producing insects from whose cocoons such a variety of heautiful and useful fabrics are manufactured. The moths belonging to this family are mostly stout, thick-bodied insects, frequently very hairy or woolly. 'They have small, sunken heads, and the antenne are often feathered, particnlarly in the males. The mouth parts are either rudimentary or wholly wanting, many of the species not being able to appropulate food of any kind in the perfect state. Their wings are usmally broad, 
and in many of the species are covered with a dense armor of seales arranged in colored patterns, frequently very gay, while in others the clothing is of more sublued tints, soft and blended. The remartable power by which the virgin females attract the males, often from long distances (referred to in a former chapter), is, to the best of my knowledge, confined exclusively to this family of moths.

The caterpillars are stout-bodied creatures, many of them densely clothed with lais's or spines. while others are fleshy and are arlorned with rows of tubercles. A few are naked and smooth.

Sylentes robinie. One may find in the trunks of poplar, ate and locust trees, protruding from large circular holes, the empty shells of this moth. Tylentes (the carpenter) is a very appropriate name for this genus of moths, as their larve mine in the solic wood of

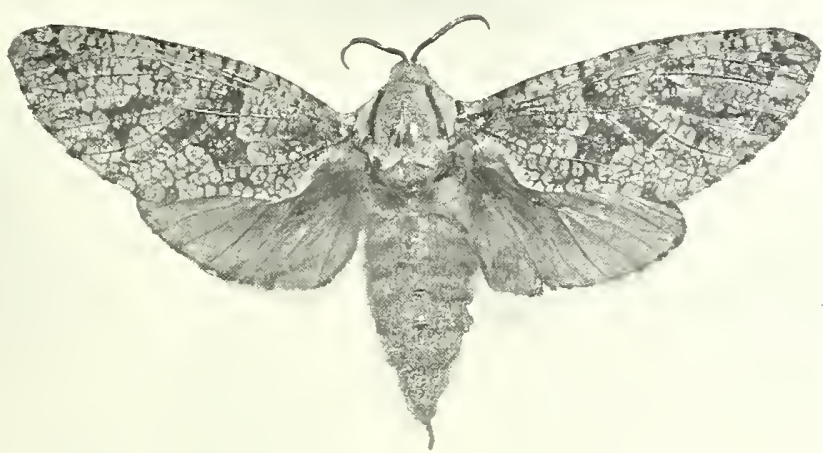

Xyleutes robinia. Female.

trees, excavating long tumnels, increasing in diameter as the caterpillars grow. Theil larve have true legs and polegs, hut are grublike looking ereatures. The present species is flesh color above and light beneath, with the head and the forward part of the body above covered with a hard slelly substance, brown in color. When fully grown the caterpillars are two or three inches long. They seem to prefer large trees and sometimes to considerable damage, riddling the trunks and carying their tumnels out through the bark before changing to pupe. They are said to require three years to reach maturity and make theil thin silken cocoons in the burows some distance from the opening, usmally lining the tumnel with silk botle front and back of their cocoons. 
The prope is yellowish-hrown, and, by means of rows of shout spines on the ahklominal segments, works its way to the month of its burrow, when the moll is ahout to heak the shell. 'The moth eomes forth in oluly, and is a niglit-flyer. The insect is very plain. Its wings are parthnent-like, resembling in some respects the eoddis lies. The female is hight gray, with a net-wonk pattern of dark bown on the fore wings. 'The head and tholax are gray, and the ablomen and lower wings are brownish-gay. The insect expands three inclies. 'The male is much smaller than the female. Its

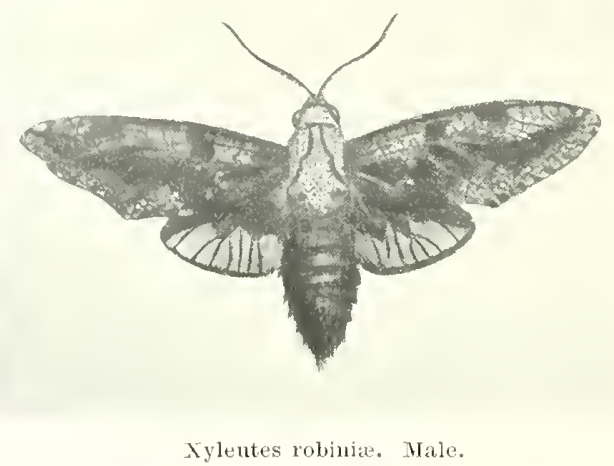

forwarl wings are of a greenish-gray and dark brown, its head and thorax gray, abmomen black, and its lower wings orange and black. Although mot a lane insect, on accomnt of its habits it is seldom seen.

Zonzern myrum. The leopard moth is a Enopean species which las been intomlued into this country. 'The wings are white, partly transparent, and malked witl a number of dark spots and rings, from which it has derived its popular name. 'The caterpillar bores tumbels in the woml of valious trees (elm, ash, maple, pear, apple, ete.), and is capable of doing a gond deal of clamage should it become very numerons. It is gellowisl, with numerous black spots on the sides and hakk, and has a horny plate on the segment next the heal. 'The noth may ocasionally be taken abont eleetric lights in the neighborhoml whare it las been introduced.

To the genus sthenopis belong some rate and interesting moths. I have made the acquaintance of but two species of this genus in this comntry, Sthenopris argentomemelatus and st. argentatr. These insects are much alike, the former being the larger, amb measuring thee and a half inches or more in expanse, while of the latter species, the only 
specimen I ever took is two and a half inches across. Their colors are ashen gray, the fore wings being crossed by bands and rows of spots of darker gray. On the fore wings are two small silvery spots.

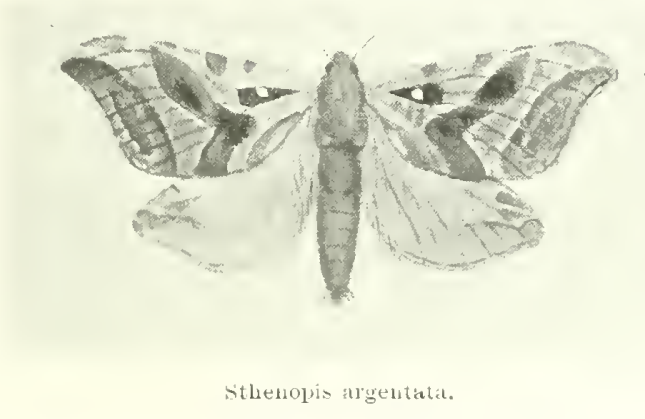

A remarkable characteristic of these moths is their exceelingly short antenne. I have never seen the larva, and the life history of these moths is not known to me. Professor Comstock states that "the larva are nearly nakerl and grub-like in appentanee, although furnished with sixteen legs. They feed upon woor and are found at the roots or within the stems of plants. 'They transform either in their burrows or in the case of those that feed outsicle of roots within loose cocoons." St. urgentomaculutu I have taken in northern Ohio, while collecting with a lamp. As it cireled about the room, it looked. with its long wings, a good deal like a large dragon-fly. I also found a specimen of the same species in the same locality in the daytime elinging to the uncler side of a blackberry leaf. S. argentutn (the species figured) I took at dusk in July in South Sudbury, Mass. It was flying slowly along the road in a wooded district, and I easily caught up with it and linoeked it lown with my hat. I lave seen species of this genus from Mexieo and Brazil; and a very large coarse-looking insect of the same genus was lately sent me from Cooktown, in Queenstanel, Anstralia.

The Laxiocompions include the tent aterpillars and the lappet caterpillans. The moths belonging to this group are downy or woolly and thiek-bodied, and are distingmisher by the lack of the loop and bristle which holds the upper and lower wings together during flight in other moths. The eaterpillars are soft-hodied ereatmes, almost velvety to the tonch. and are clotherl with short soft hairs, thickest on the sides, which do not arise from warts or tubercles. The antemie of these moths are feathered more broadly in the 
males than in the females. When at rest the wings are folded in such a way that they slant both sicles of the ablomen like a roof, and the lower wing project on the sides, not being wholly eovered by the mper wings. 'The moths are night-flyers. Some of the larve are glegarious, living in colonies, frequently in immense numbers. fome species feed on entivated trees, and on accomnt of their vast numbers sometimes do inmense danige. 'The pupa state is passed in a cocoon composed mostly of silken thearls.

A numeroms and most destruetive speeies helonging to this group in the East is Clisiocomple americana, the fent caterpillaw, whose msightly wehs of latge dimensions are to be seen ahmost everywhere inneghected apple ordurels and by the rodshide on wild cherry-trees. 'The exgs of the female moth are deforited in a compact mass or bunch neal the encl of a twig, of its chosen food plant, partly or wholly (meireling it. 'They are cylindrical in shape and are placed on ent chose together often thee or four hundred in a bunch and covered with a shining brown water-proof varnish which protects them from the weather. In this state they remain during the fall and winter, and hatch about the time that the leaf-huds are ready to hurst. in May. The young caterpillars construct in the fork of a hranch a small triangular web or tent of fine silken webs in which they remain through the night and during coll or stormy weather, sallying forth in long lines, ustally in single file, each caterpillar spinning its web, presmmably to enable it to retrace its steps as it alvances to the ends of the twigs to feed upon the opening foliage. In time these lines of silk extend to the tips of all the immediate branches about the nest, which is arded to as the individuals eomposing the colony grow in size. As they remain in this tent at all times when not engaged in feeding or in wandering to and from their feeding grounds, it is a veritable home, and in time becomes latge and strong, capblule of resisting the attacks of most birds and of all palasitic insects. When the eaterpillars reach maturity they are ahout two inches long, spasely clother with soft hairs thicker on the sides, with blak hearls, and are striped lengthwise with white, yellow and back, with a blue spot in the midhle of each segment on ench side. When abont to pruate they abandon their tent and seprately wamler off in search of a suitable locality in which to spin their eocooms.

These are spm in erevices in the hark of trees, about fences and stone walls, fregnently on huildings on the elaphoards or muder the 
eaves. They are oval in form, light colored and thin, and intermixerl with the threads is a yellowish-white sulstance which seems to give stiffness to the cocoon. About two weeks after the cocoon is finished the moth makes its escape through a loole in one end which it moistens, it is said, with a secretion from its mouth, enabling the insect to push the loosened threads aside. The moth expands from an inch

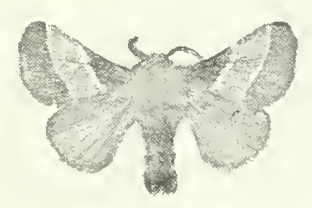

Clisiocampa americana.

to an inch and a half or over, the male being smaller than the female. The body of the insect is woolly, and is of a rusty brown color, its fore wings being crossed by a lighter band edged on either side by a narrow grayish-yellow line. The male is somewhat darker than the female.

This insect in its caterpillar state is so injurious to apple orchards that its destruction becomes a necessity to keep the trees in bearing condition. It is not a difficult insect to combat, as its clusters of eggs are easily seen during the fall and winter. and can be pickerl off by hand and burned. When the young larve first begin their operations in the spring their nests may easily be taken from the trees anr each colony destroyed in its infancy. To insure success in this work the tents should be removed either early in the morning or late in the afternoon, or else on stormy days when the whole colony is at home. A piece of coarse lurlap wound around the end of a pole and saturated with kerosene oil will be foumd well fitted for the work, als the oil will destroy the caterpillars which it touches even if they are not removed with the tent. To keep one ss orchard cleared of these pests the nests should be destroyed not only on the orchard trees but also on all neglected trees in the neighborhood infested by them, especially the wild cherry-tree, which seems to be the favorite frod plant of the species. Two or three neglected trees will breed moths enough to stock several orchards with the pest the following spring.

The parasites probably do more to hold these insects in check than all other agents (man included) put together. If one will 
closely watch a colony of the tent caterpillar's when out of their nest or a large number of lante of any otlier kind, he may see a small swarm of ichneumon flies constantly hovering alout and over them. 'These are on the watch for a chance to deposit their eggss in or on the bodies of the catergillar's; and when one considers their numbers and persistency, one womlers that a sufficient number of the larve escape to propagate the species. Here is an instance which gives some idea of their ravages. One of my hrothers had one humbed caterpillars of a latger species he wished to raise whieh he placed on a young tree and enclosed the whole in mosquito netting. Under this net they remained until nearly full grown, when one day a small rent was discovered in one coner of the net presumably made liy a bird: and when the larve were taken ont and examined, of the entire number but three had escaped the ichnemman flies which had found their way into the net and laid their eggos on the caterpillars.

While a species is comparatively searce, its clamees of escape from limels and parasitic insects are fairly good and if it is a prolific

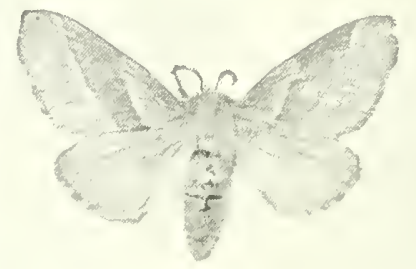

Clisiocampa disstria.

species well adapted to its surroundings and has plenty of food, it will incerease until its posterity may be recknned by millions. It now begins to attract attention, both from the birds and the parasites, as a large amount of food going to waste. 'The parasites attack it, and laving an abundance of food begin to increase at a rapid rate; and the hirds finding an easily obtained food-supply neglect other foods and alply themselves to this. The consequence is that the demand som ecpuals and finally exceeds the supply, and an entire region Inevionsly infested with an injurions insect may be so depopulated in one or two seasons that a careless olserver might conchule that the suecies was extinct or had migrated to other partis. This, in my opinion, is the explanation of the sudden disappearance of many an 
insect pest which may have at one time threatened the destruction of the plants upon which it sulssisted.

The forest tent caterpillar, Clisiocampa disstria, resembles the preceding species both in its habits and in the general appearance of the caterpillar and moth. The larva is more bluish than the common tent caterpillar, has a row of spots along the back instead of lines, is greenish on the sides and has a blue head. It lives in large colonies of three or four hundred individuals on oaks and walnuts, and makes a large tent beneath which it remains except when feeding. 'This insect I have seen very abundant in the White Mountain region of New Hampshire, where it not only devoured the leaves of the oak and walnut, but also apple, cherry, and when hard pressed even birch, alder and elm. The insects were nearty full grown by the middle of June. 'The moth is about the same size as the preceding, but is of a more reddish-tan color, and the fore wings are crossed by a lroad band of a darker shade. It is an inhabitant of all the New England and Middle States.

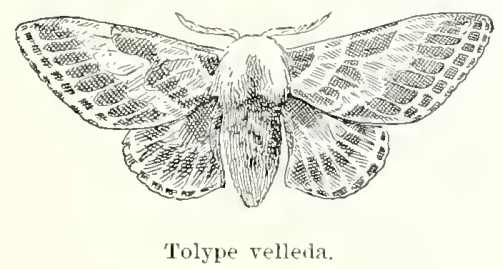

The lappet moth. Tolype velleda, is a pretty and interesting species. The larva is very much flattened beneath, and along its sides are a number of flat projections or lappets from which spring numerous hairs making a fringe around the body. When the insect is not feeding it hugs closely to the bark of the tree, the hairs on it sides lie flat against its support; and as its colors are dull greenish-gray, it looks like nothing on earth so much as a swelling on the bark. One may even gaze directly upon it without realizing that it is anything alive. The larva is orange, sometimes red beneath and has an intensely back band between two of the segments on the upper side on the forward part of the body. This band does not show when the insect is at rest. It feeds upon the apple, poplar and willow, and reaches full size during July, when it is two inches or more in length. It spins a thick gray-brown cocoon, oval in shape, conver above, flat and very thin on the under side, and spreading out on the edges like 
thin paper, attacherl to the trunk or a limb of the tree upon which the larva ferl. The chrysalis is dark brown and very smonth. The moth makes its appearance carly in September and is a night-flyer, occasionally attracted to lighted lamps. Its color's are soft and blended, being white shater with blue-gray, and its wings crossed by two hroad bands of dark gray. The female moth expands two and one-half inches, but the male is smaller, expanding but one and one-lialf inches.

Another species, closely related to the preceding but smaller, is Tolype lericis, which lives on the lareh. Its larva is brownish-gray in color and alout an inch and a half long. Its habits are much like

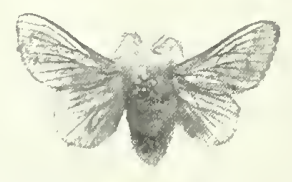

Tolype larieis.

T. vellode, and it makes a similar though smatler cocom. The moth emerges early in September and lays its eggrs, whieh do not hatch till the following spring. The female moth resembles $T$ '. velleda in color, except that it is lighter near the borly, and the outer gray band on the forward wings is darker and narrower. The male, whieh is here figmed, is dark gray with clourled wings. The alsdomen is sonty biak. Acombing to my experience this is a rare moth.

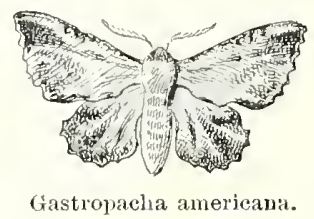

Gestiopuerlen americane is a reddish-brown moth with a lighter lanul crosing the wings, edgerl with wavy dark hrown lines and having the ertges of the wings sealloped. There is a good deal of discrepancy in size between the male and female, a good-sized specimen of the latter sprealing two inches. The larva feeds on apple, birch, maphe and ash. It is flattened beneath and fringed with hairs 
on the sicles, like $T$. vellota. It is gray above, with inegular white spots, and striped with sooty hlack, laving two sculet bands crosing the forward part of the body, on each of which are three black spots. The under side is orange.

The caterpillar measures over two inches in length when fully grown, and makes a gray-ibrow cocoon on the tree upon which it feeds. The moth emerges in June or early in July.

'To the genus Anisota belong several pretty native insects. They are not large, the largest spreading less than three inches. The sexes differ so much in coloring, size and shape as to scalleely be recognized as the same species. The antenne of the females are narow, while in the males they are pectinated for two-thirds of their length. The larve feer on various forest trees and are sometimes so abundant as to completely strip the trees of their leaves. These insects pulpate in the gromend.

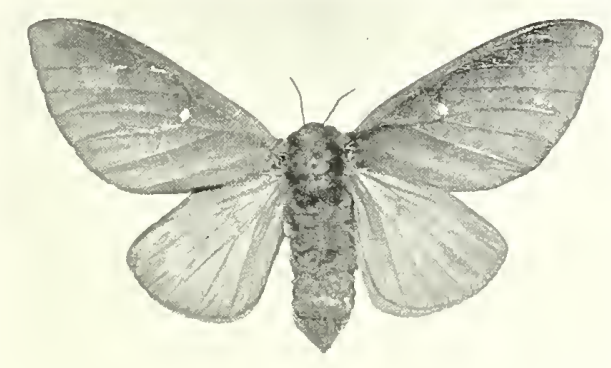

Auisuta senatoria.

Anisota senutoria is a common species in the eastern United States and Canala, and may be taken the latter part of June about electric lights at night or found in the daytine clinging to grass-stalks under oak-trees, where they have rested to expand their wings after leaving the chrysalis shell. The female moth deposits her eggs in clusters on the under side of the leaves of oak-trees. and the larva may sometimes be seen in immense numbers.

'They are apparently gregarions during their entire caterpillar' state and in casting their skins they congregate on the ends of the twigs leaving their wrinkled cast-off coverings where they often remain after the larve are full grown and have departed. When young they eat only the small and tender leares, lerouring the 
larger and tougher ones as they grow in size and strength, often stripling whole acres of forests of their leaves. When not feeding, the caterpillars congregate in immense clusters, bending down the smatler twigs with their weight. They are dark blown or black in color, with datk ocheous yellow stripes on their sides and back, and are amed with short spines on each segment, and two homs on the segment mext the learl. They are stiff, lard and rough when fully grown, and during the early part of September exw down the trees and burow five of six inches into the ground, where they remain in the pupa state during the winter. The cluysalis is hard and spiny: and when the moth is abont to break the slell it works its way to the surface, whele the enpty ease may be found protruding fiom the groumd after the insect has flown. The femate moth expands two and a half inches, and is of an ocheous yellow color, witl a reddish rast, tinged slightly witl pruple along the outer margin of the fore wings. The npper wings are stippled with faint brown spots and have a small white dot near the centre. 'T'le male is much smaller than the female. Its wings look small in proportion to its body and ane proplish-brown, darker towad the tips of the fore wings, which have a white spot in the centre.

Lreisote stigme is not nearly so common an insect as the preeerling species, and I have never seen it abundant. The habits of the eaterpillar are similar to those of $A$. senatoria : but it is nuch lighter in color, being a tawny orange with dark stripes on its sides and back. Its spines are also longer. The female moth very much resembles 1. somertor, but is rieler and more reddish in eoloring, with larger spots of dark brown or black on its wings. The mate is more like the female in color than is the male of the other species, and has a large white spot in the centre of the forc wings. 'The wings are also spotted with dark brown. This insect varies a good deal in the intensity of its coloring. Especially is this the case with the male, which is sometimes almost red. The male expands an incli and three-quaters and the female nearly three inches.

In Anisota virfiniensis the scales are thinly scattered over the wings, so that they appear almost tramsparent. The female is more purple than the other two species, and liveks the sprinkle of brown spots. 'The male is snatl and purple-brown in eolor, with a scaleless, trans]anent patch in the middle of each of the wings. This insect I have never fomml abmolant. The female moth is about the size of A. sematorin, but the male is smaller than the male of that speeies. 
The larva of this inseet, like the two preceding, lives on the oals. It is of a dull grayish-green color, with indistinct stripes of pinlishl, and is stippled with white dots. It is armed with short spines and horns. and, hike the other species of the genus, is mogh and hard.

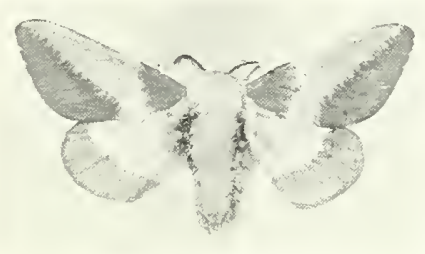

Anisota rubieurd:

Anisota rubicunde is very variable in its abundance or scarcity, and is sometimes to be taken in numbers where, during the next season, it may be rare. The species is usually very abundant in Waslington, D. C.. where the larra lives on the malle-trees, frequently loing much damage. The trees in the Smothsonian grounds are infested with the caterpillars, and the perfect insects just out of their chrysalids may be taken by the dozen in June dinging to the grass stalks muder the trees. One may even gather the live chrysilides as

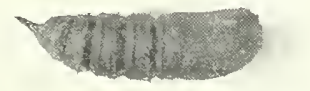

Chrysalis of Anisota rubicunda.

they protrude from their burrows and have the pleasure of watching the imprisoned moth emerge in one's own room. It is a beautiful insect. The fore wing's are a delicate pink with a wide yellow band crossing them diagonally, while the lower wings are yellow with the lower margin pink. The body is yellow, and very soft and downy. The males are much smaller than their mates, and their coloring is usually much stronger. The insect sprearls from one and a half to two and a half inches. The lava is two inches long, is light green striped longitudinally with dark green, and is horned in front, spiny along its back and sides, and is finm and rough to the touch. It 
seems to be more plentiful in the South than the North, and is, I believe, a rare insect in New England.

We now cone to the two genera C'ithermin and Eereles, the royal mothis, both represented by large species. They are very stont-bodied noths and hairy or woolly. 'The antenne of the males are broadly pectinated for two-thinds of their length, the same organs of the females heing simple. Their wings ate strong, but they fly only by night. The larve are armed with horms on the forward part of their. bodies and ale also somewhat hairy. They spin no cocoons, lnt pass the winter in the pupa state moler gromul. 'The chrysalis is spiny on the abiominal segments, dombtless to enable it to push itself up to the surface when the moth is ahont to break the shell.

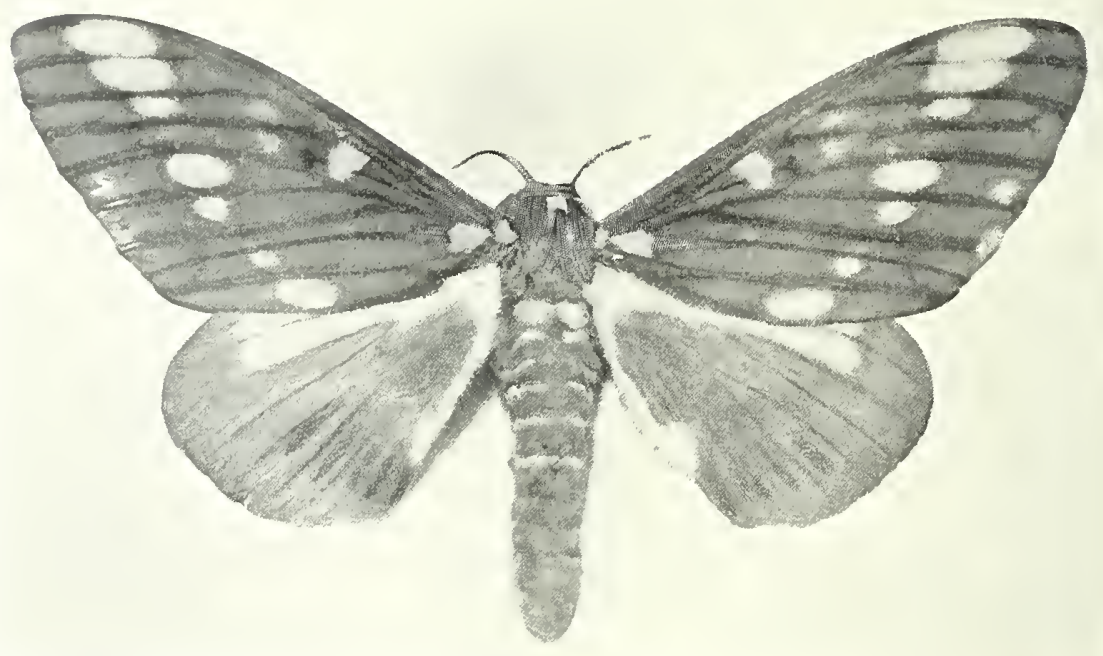

Githeronia regalis. Mnle.

Cithermia requlis is a lane and strikingly marked inseet, and is not rare in the Sonth and West, where the eaterpillar feeds on the leaves of the walnut, hickory, hutternut and persimmon. The sexes frequently differ very much in size, although sinilarly maked. A gool-sized male will measure fonr inches across its expanded wings, and a female six or more. I have a grand female specimen of this insect from Gainesville, Va, which is nearly seven inches across. 
The body is reddish-orange, with yellow spots and lines on the thorax. The upper wings are olive streaked with broad reddish lines which follow the veins, and a number of large yellow spots are distributed over the wings as shown in the illustration. The lower wings are reddish-orange, with a few vague olive makings between the veins, a large spot and a defused band of yellow near the npper margin, which is usually covered with the uprer wings. I have taken this fine moth about the electric lights in Washington. D. C., where it is not rare, have found specimens in Illinois and Arkansas, and have no doubt but that it inhabits all the Southern and Western States as far west as Kansas; but it must he considered a rare insect in northern New England.

An insect very closely allied to this I have seen in collections from Mexico, also from Colombia and Brazil, Sonth America.

A friend living in Norwich, Conn.. has succeeded in finding the larva of this moth there for several consecutive years, feeding on the leaves of the sumac, and has reared the perfect insects, of which he has sent me specimens.

The caterpillar is one of our largest, if not the very largest, being four or five inches in length, thick in proportion and very formidable in appearance, owing to a number of large curved spines with which it is armed on the forward part of the body. It is green in color, banded across the rings with blue. The head, legs and large spines near the head are orange and the shorter spines black. Although a formidable-looking creature, it is perfectly harmless. When rearly to pupate in September, the insect burrows into the ground, where it transforms into a stout brown chrysalis. This chrysalis works its way to the surface of the ground the latter part of the following June, and the fly emerging crawls to a neighboring bush, and there hangs suspended until its wings have developed and are rigid enough to support it in flight. It is a sluggish insect, and when found may be carried home on the twig to which it is attached without danger of its taking Hight.

Eactes imperialis resembles the preceding. both in the larval and perfect state. Although not differing greatly in size. the males being slightly smaller than their mates, there is a marked difference in the coloring of the sexes. 'The ground color' of both male and female is a rich yellowish-buff. In the male the forward wings are brownish-purple on the inner half. connected with a broad band of the same color extending along the outer margin. The lower wings 
liave an irregular wavy line of the same eolor crossing them with a round spot and a vague patch above. Both upper and lower wings, partienlarly the former, are stippled with blended spots of dark brown or biak. The thorax and abdomen are mottled with yellowish-buff and hownish-purple. 'The female is lighter than her mate, all four wings being erosied with a band of hrownish-purple, with an irregular clouded patch of the same color at the base of each wing near the borly. The borly is mottled and the wings stippled much the same as with the male. 1 gool-sized specimen of this fine inseet will measure five and a half inches acouss its expanded wings. It is not me throughout the eastern half of the United States and Camarla, and two or thee chsely allied species or varieties of the same species (one of them considerably larger than our own) oceur throughout Mexieo and temperate and tropieal South Imerica.

'The eggs are deposited singly on the button-wood, oak, and the different species of pine, and the caterpillars may be found full grown in September. 'They are usually dark green in eolor, although oceasionally brown or even black, three or four inches long when full grown, and are rather hairy. Each segment is armerl with short rough spines, with fonr larger ones on the forward part of the borly.

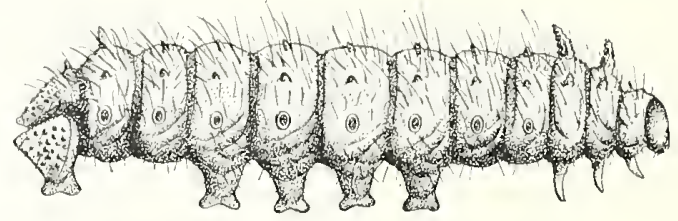

Larva of Eacles imperialis.

'The spiricles are very distinctly marked on the sides. The larva burrows into the ground, where it transforms into a chysalis, remaining in this state during the winter. The chrysalis, which is much like that of C. romlis, makes its way to the surface of the gromul, where it emerges a moth in. June, and the empty pupa case may be found partly protrurling from its burrow after the moth has flown.

As the larva of this insect is a large and stout creature, it might be supposed that it would be realily seen; but as it is frequently loeated on the light banches of large trees and is usnally of the same color as the leaves, it is not an casy insect to find. Where pine or sycamore trees overhang a road or a well-worn path the luge pellets 


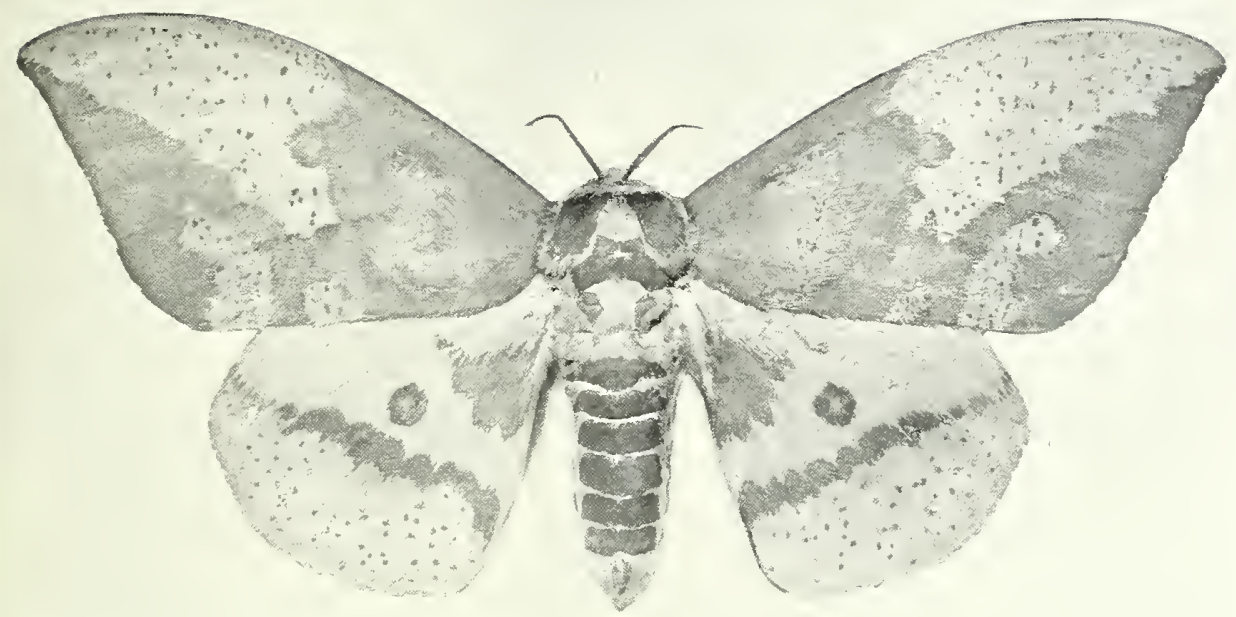

Male Moth.

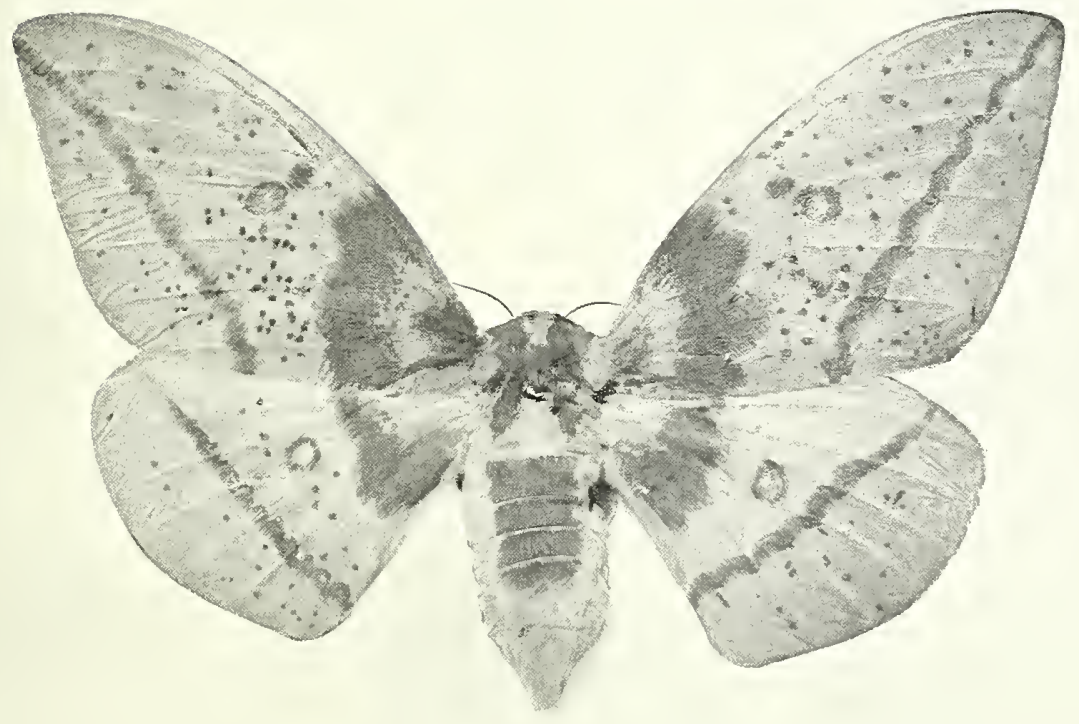

Female Moth.

EACLES IMPERIALIS. 

of excrement dropped by the caterpillar will enable one to search out its whereabouts. When found it is not an easy thing to dislodge him, as he has a tenacious grasp of the twig to which he clings. The moth is sluggish in its movements, but flies well when once on the wing, and may occasionally be taken about electrie lights.

Satumia io is a familiar insect to most persons having a slight acquaintance with our native lepidopteria, and like several other native insects belonging to this family of Bombycice is a very lovely creature. The predominating color of the male, which expands three

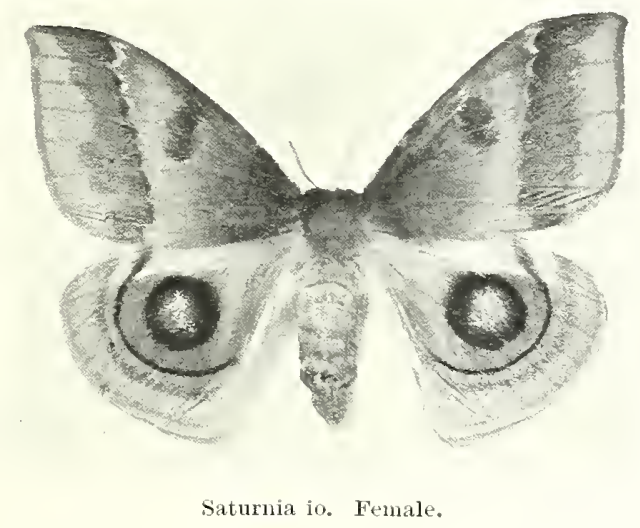

inches, is a yellowish-buff, deeper on the lower wings, the fore wings having a purple-brown spot a little above the centre of the wing, with two wavy lines near the outer margin, and one near the base of the wing, of the same color. In the middle of the lower wing is a large bluish spot with a white centre, having a broad ring of black encircling it. Outside of this is a sharp black line and then a reddish-purple line which broadens out into a wide band on the inner margin. The body is yellow, and the antenne, which are red, are broad and pectinated. The female is considerably larger than the male. The upper wings are a deep brownish-purple crossed by darker bands edged with fine wary lines of yellow. The lower wings are much like those of the male except that the bluish spot is larger in proportion and the color's generally darker. The thorax is purple-brown and the abdomen reddish-brown. The antemie are narrow and slightly pectinated.

The eggs of the female are laid on the leaves of a variety of trees - oak, willow, locust, poplar, apple, ete., — and are deposited in a 
compact patch of from thinty to eighty, or more, on the muler side of a leat. When the eaterpilars hateh they are reddish-brown in color and covered with minute spines. 'They are gregarious in their habits during the earlier part of their existence feeding, resting and moving from place to place in regular order. When half-grown they seprate, and huring the remainder of the caterpillar state shift for themselves. The mature larva is two and a lialf inches long, of a

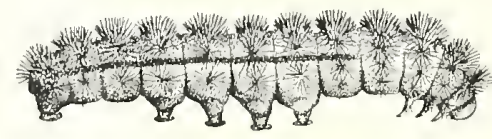

Lirva of Saturuia io.

light green aolor, with a white stripe erlgerl with reddish-purple extending along the sirles. It is profusely covered with branching spines which are very sharp, amb when carelessly touched sting like the nettle, rausing the part affected to swell into whitish pimples, smarting painfully for an hour or two. When about to pupate the larva descencls to the ground, where it haws together a few dead
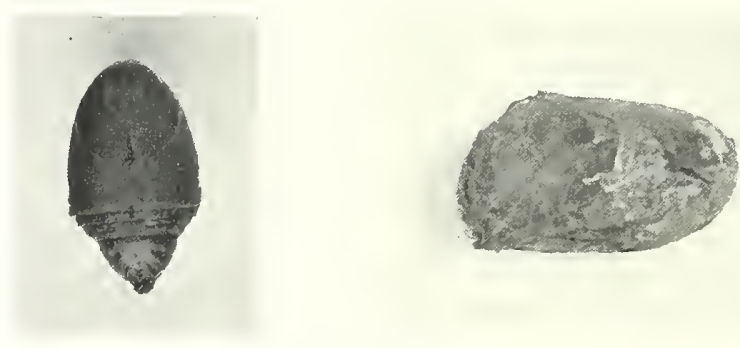

Chrysalis aul cocoon of Saturnia io.

leaves and spins among them a thin, incegnlar, hown cocoon, in which it passes the winter, coming out as a moth late the following June. This insect is readily attracter with a bright light, and the males may be assembled in numbers with a captive female.

Saturnin main. When the leaves of the ank are mufolding in the spring eolonies of small, dark brown, spiny lanve may be fomd on them by liligent search. These are the young of the maia moth, and they nay be easily reared by enclosing a small serub-oak in moseguito netting and allowing the larve to feed. As the lanve mature they 
become solitary in their habits, and when fully grown are three inches long, anr, like the precerling, are covered with shar' branching spines which sting, but in a less degree than Satmmiu io. if the insect is handled carelessly. The larva is brown in color, with reddishbrown head and legs, the tubercles at the base of the spines being also redulish-brown. When about to pupate the caterpillar crawls to the glound and, drawing a collection of leaves and sticks together, spins a loose. thin cocoon anong them.

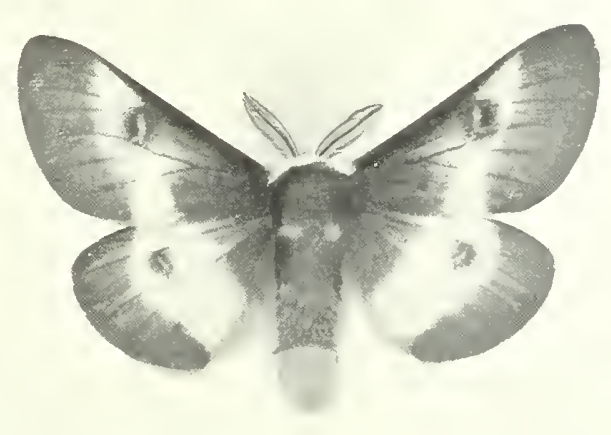

Saturnia maı. Male.

The moth emerges late in the fall, usually about the middle of October, and is one of the last of our lepidoptera which the collector may take on the wing. The maia moth is a day-flier, and may be seen on mild autumn days when the woods and fields are brown, hovering over the shrubby oaks.

The males are easily assembled with a captive female. The sexes are readily distinguished from each other. The male has a broml fuather-like antenna (while that of the female is narrow) and the end of the abromen is arlorned with a tuft of red hails which the female does not have. 'The wings seem to be thinly covered with scales, and on that account are partly tiansparent.

This moth is often very local, and may le abundant in one locality while scarce in another, apparently as favorable to its habitation. It may be readily taken on the wing with the net, and when fresh and perfect is an exceedingly pretty insect, its colors of soft blackish-brown, creany-white, and bright red harmonizing in a pleasing manner. 'The female may sometimes be found by watching the 
movements of the males, who seem to scent them out, fluttering near the spot where the female rests concealed on a serub-oak.

Next in order comes the group of moths called Attuci, whieh inclurles many of the largest silk-produeing species.

Attecus recropin is our largest native silk-spinning insect, and easily holds its place among the giant lepidoptera of the world. speeimens are oecasionally taken six and one-half or even seven inches from tip to tip of their extended wings: and were it not so common, it would he nuch higher prized by collectors. When fresh from the cocoon, its wings (still soft, lut fully expanded) have the alpearance of being a part of some rich and heavy fabric, and a gentleman with whom I am acruainted having interests in a woollen mill, remanked, on seeing one of these gramel moths for the first time, "Now if I conld manufacture a piece of goods like that, I think it would sell." The sublued colors and the delicately traced patterns of many of the moths would, if imitated in fabries, give greater variety and more artistic effects to the materials used for our adomment and confort. The female cecropia moth, the bulk of whose enormons borly is composed almost wholly of eggs (two or three hundred in number), lays them singly or at the most two or three together on the under sidle of the leaves of the food plant. 'These eggs are circular in shape, slightly hattened above and below, and

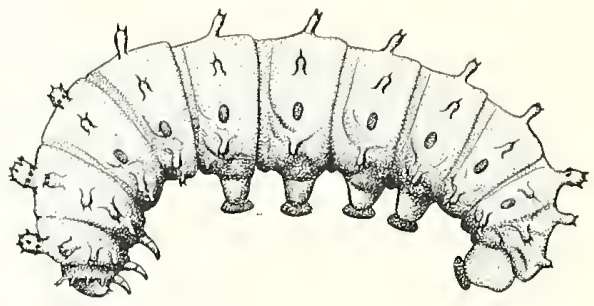

Larva of Attreus cecropia.

are creany-white in color: The young caterpillars make their appearance in ten or twelve days and are at first dark brown or black, covered with minute tulercles and stout black spines. At each moult they change in color, and when three-quarters of an inch long are orange or deep yellow studded with black tubereles and spines. The insect assumes a greenish and finally a beautiful bluish-green color as it matures, eventually reaching a length of three or four inches and a thickness of one's thumb. It is then an imposing-look- 


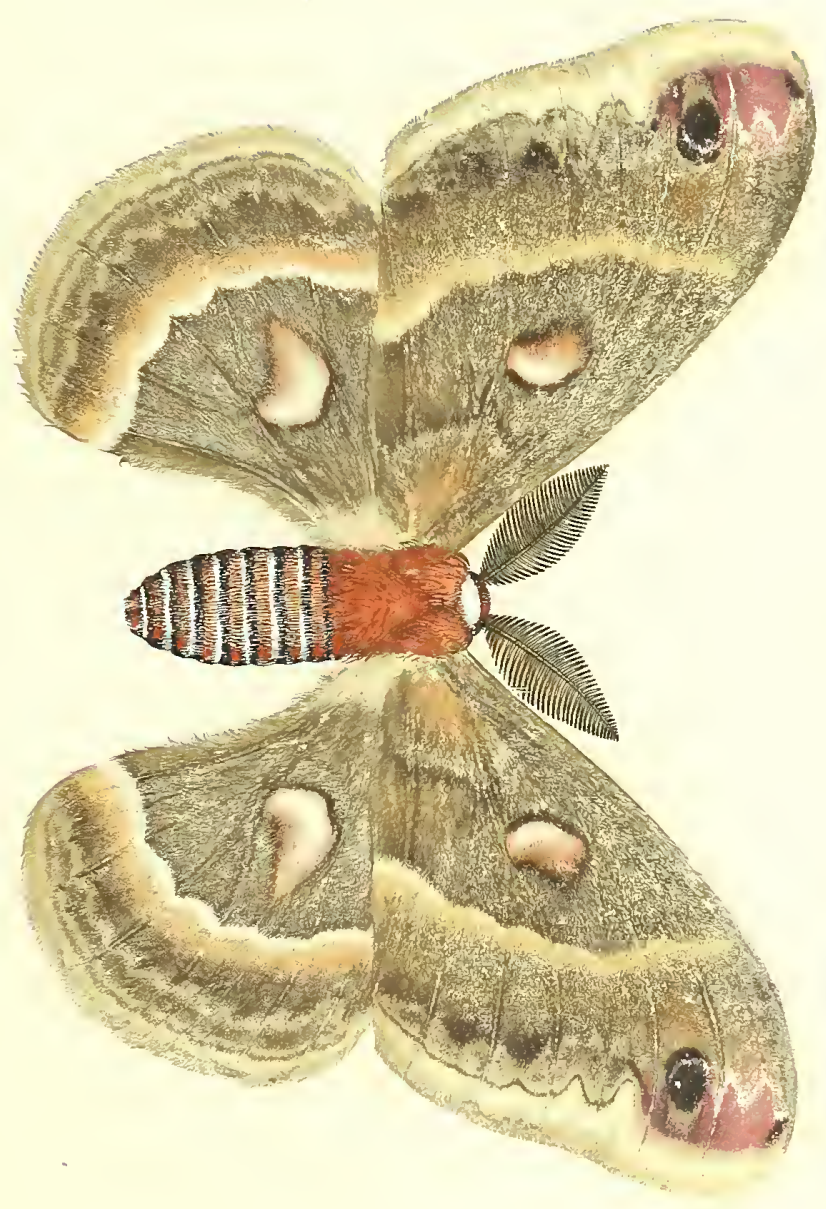



ing creature with large coral-red tubercles on the forward part of its body, yellow ones on its back, and smaller blue ones on its sides and about its head, all covered with short black bristles. It clasps the bough or twig on which it rests with a wonderful tenacity, and if placed on one's finger the grasp, of its Heshy feet with their minute hooks is very noticeathle. It has a peculiar odor, both in the larva and the moth state, which may be of some protection to the animal.

'l'oward the end of septcmber the caterpillar' constructs its coarse, brown, elongated cocoon, which is usually attached on one side to a twig or branch. 'This cocoon is eomposed of two parts, consisting of a loose, wrinkled outer covering and a well-shaped and dense inner pod. with fine floss silk separating the two, which are both loosely

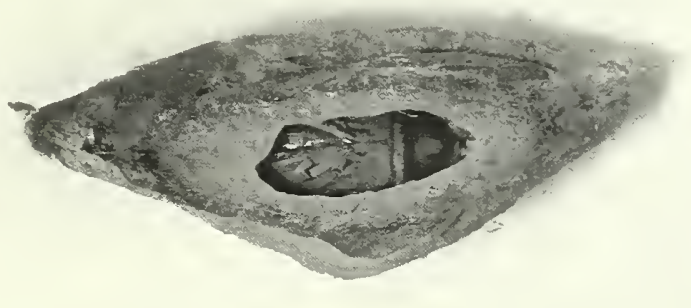

section of cocoon of Attacus cecropia.

spun at one end to enable the moth to make its escape. There is frequently a marked difference between the cocoons foumd on trees and shrubs on high glound and those taken from low bushes and shrubs in swampy distriets. The latter are frequently two or three times as large externally as the upland variety, and have a large amount of the floss silk hetween the outer and inmer coverings. This variation I camnot explain, and have noticed no difference in the moths emerging from the two varieties of cocoons other than that the swamp-inhabiting specimens appear larger and richer in coloring than their upland relations. Sometimes the cocoons of these species are to be found in large numbers. In the suburbs of Chicago they may be seen on the shade trees in dozens and sometimes in hundreds; and I have known two men to collect a bushel of them in 
this locality in half a day. The moth emerges about the 20 the of fune, ustally in the monning; and by evening its wings are rigid and it is ready to take flight. As these moths take 110 nourishment thein lives are very slort after reaching maturity. Resting hidken
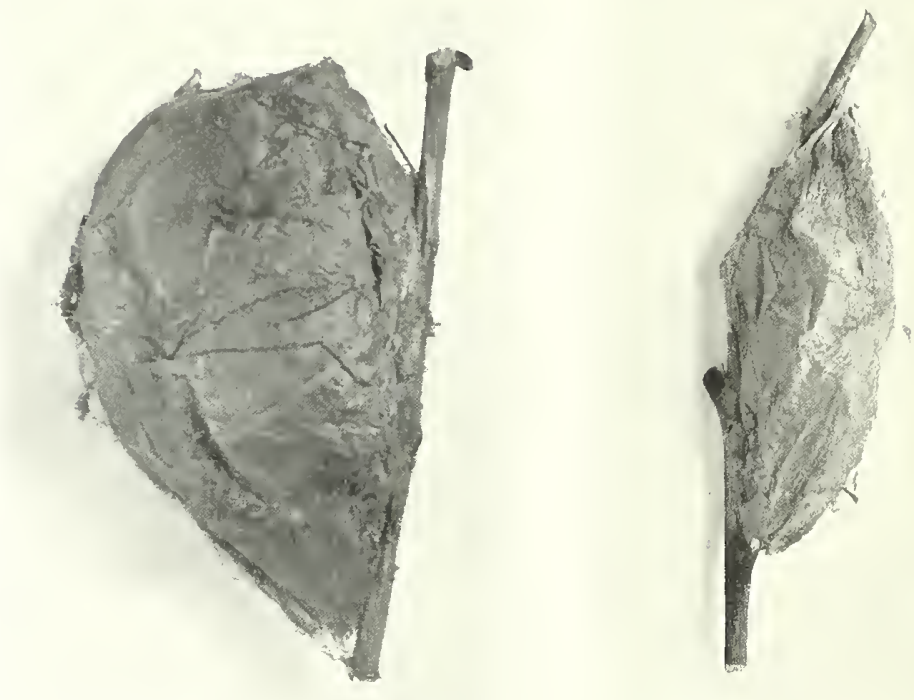

Swanp and mplakl forms of cosoons of Attacus cecopia.

by day anong the leaves, the males sally fortlo at evening in search of their mates guided hy their leen sense of smell, and laving insured. the continnance of the species for another year, they soon perish.

This insect inlabbits a large part of the continent east of the Rocky Mountains. In Colorado, Utalı, California and the far West generally its place is oceupied by elosely allied forms. very large and leatyy-hodied insects, in which red and dark brown colors predominate. T'wo or thee species of Atturns from Mexion are interesting, from having a transarent almond-shaped spot in the centre of each wing. One of these, Attrems splomlens, is a lovely ereature, on whose wings pink, hrown, purple, blaek and white are mingled, making a very pleasing eomlination. There is frequently great variation in the eoloring of these moths.

Attacus cynthia is a species which has been introdueed into this country and Europe from China, and may now be found in a wild 


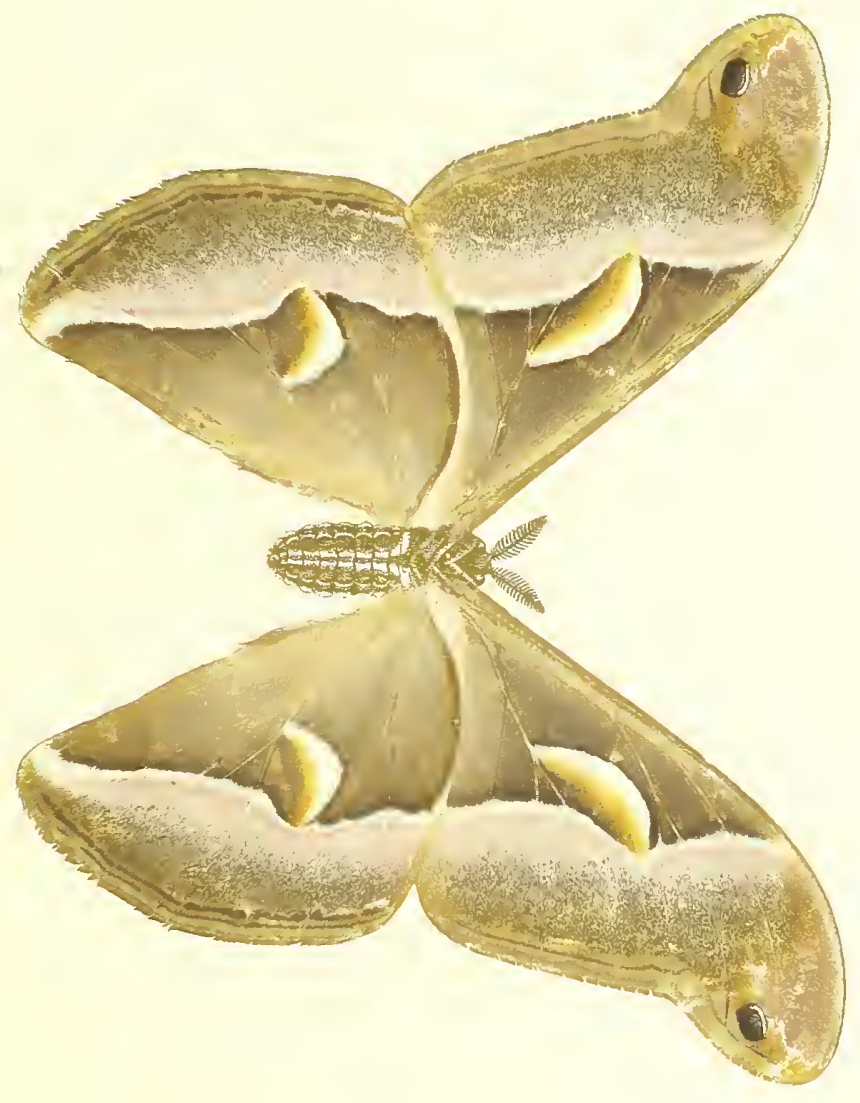



state in the vieinity of New York City, Philadelplia and other places where its food plant, the alanthus, has been cultivated as a shade tree. It becanie so common in Philadelphia and Washington. D. C., at one time as to be a pest. and threatened the lestruction of the trees: hut the parasites and birds seem now able to cope with it and hold it in cheok.

This insect is reared in ssiatic comntries for its silk, which is said to be strong and rely durable, but lacks the beanty of that produced by Bombly mori. It was pobibly for its silk that it was introduced into this country. hut that it has erel been successfully utilized here for the manufacture of fabrios I lave ret to learn. The female lays two humber to three humber cream-colored eggs. anr the young caterpillars are yellowish pofusely adorned with black spots and tubercles. The mature caterpillatr is three inches long, of a elear hluish-green color adorned with hlue tubercles. The cocoon is similar in shape to that produced by the next species described, Attraces promethin. and is a little larger.

In some parts of the comntry the insect is double-lnooderl, the second brood remaining in its cocoons during the winter months, coming out late in Jume. The moth is a fine latge insect, expanding, in large specimens, four or five inches. The females are usmally a good real larger, with broader wings than their mates.

Attums promethe is a rery abundant species thoughout a large part of the Enited States and Camada. and is one of the first of the family with whose life history the amateur collector is likely to become acquainted. The female moth deposits hel eggs in Iuly on the twigs of the wild cherry, sassafras and button-busli, sometimes five or six together and at others twenty or thirty or more in a

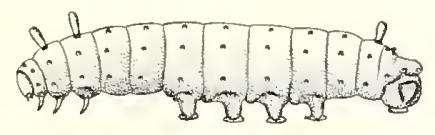

Larva of Attacus promethia.

cluster: and toward the end of that month the minute caterpoilars matie their way out and momnt to the top of the tree or bush, where they may be found feeding on the tender young leaves. When fully grown the caterpillar is one of the handsomest, being two inches long, half an inch thick, very smooth and plump, and of a light bluish-green color. There are four cylindrical coral-red tubercles on 
the nplere part of the borly just buek of the head and a large yellow one near the tail ent. Numerous small blue warts oceur in regular order on the back and sides. 'The hearl, legs and posterior part of the body are yellow. While feeding these anterpillars usually remanin among the temele leaves on the new growth, and several are generally found in elose proximity. On leawing maturity the caterpillar deseends to the lower part of the bush and begins spinning its coconn. Ifter selecting a leaf suitalse for its purpose, it commences ly spinning a quantity of silk along the branch and down the stem of the leaf in order to matse it secure for the winter.

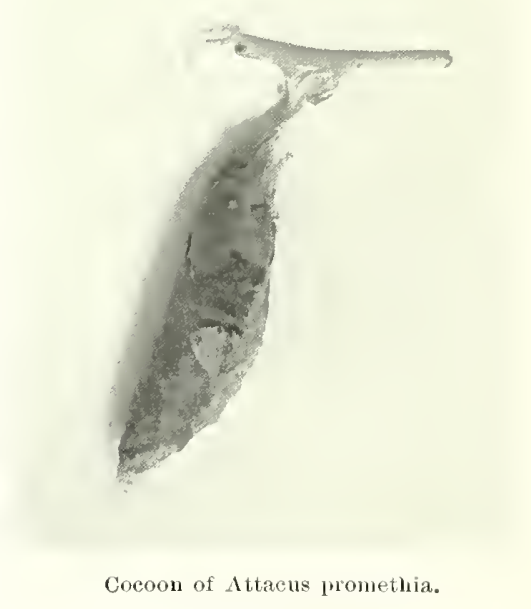

It then dhaws the sides of the leaf together with silk, and therein spins its tongh, brownish eocoon. The silk is very strong, and the eocoms are attached so fimly to the twigs by their stender cord that they ride seame for the winter. In fact, one may often find cocoons which have weathered the blasts of several seasons still firmly attached. The mper end of the cocoon, which is double like Attrews cecopra, is so lonsely spun that the moth has little difficulty in foreing its way ont. This silk could polnably be mate useful in the arts, as it is very stroms and duable and the eaterpillars could be reared in the open an in comntless thomsands with little difficulty.

'The moths emerge firm the cocoons the latter part of June and the timst of only, the females differing so much from the males as easily to be mistaken for different species. The male is a very oily 


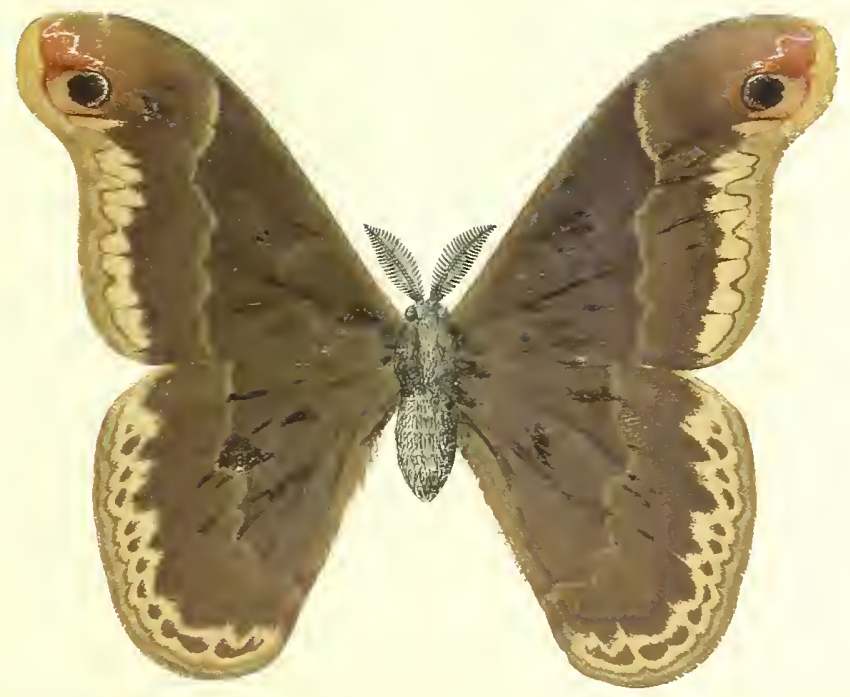

UPOER SIDE

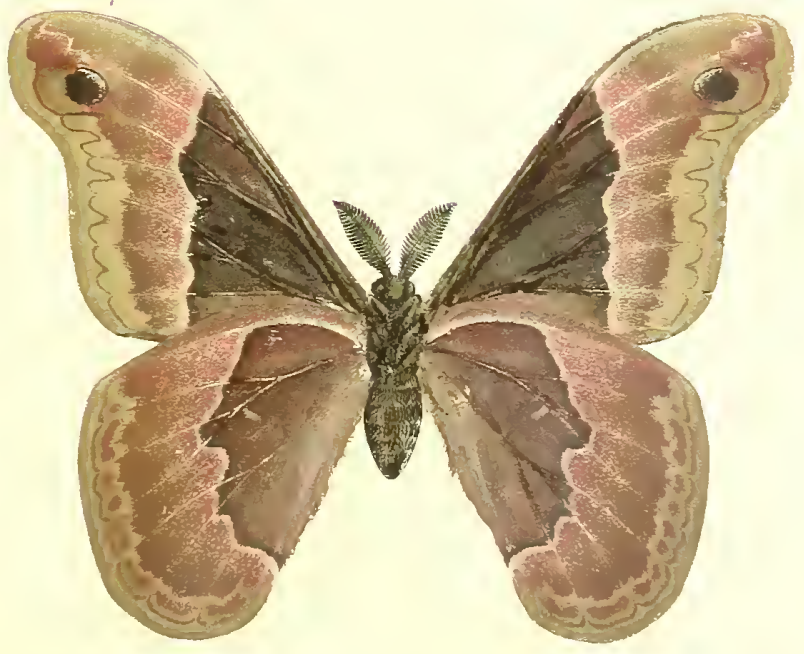

UNDER SIDE 


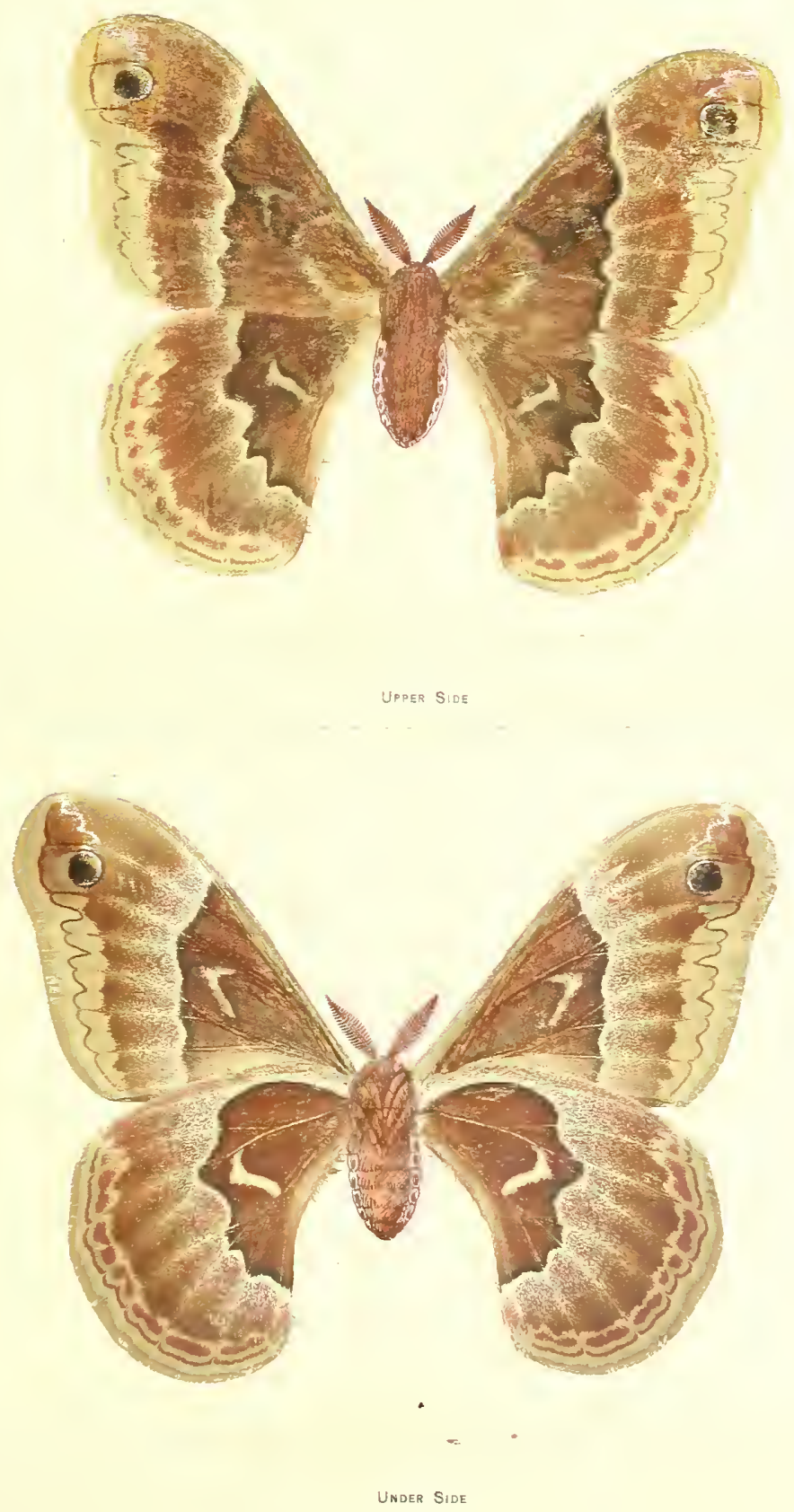



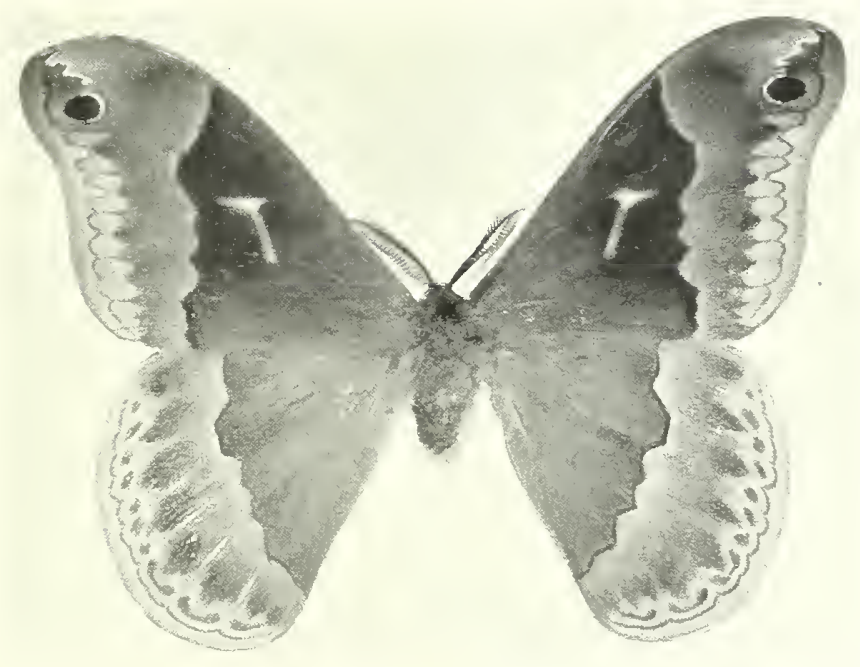

Male Moth.

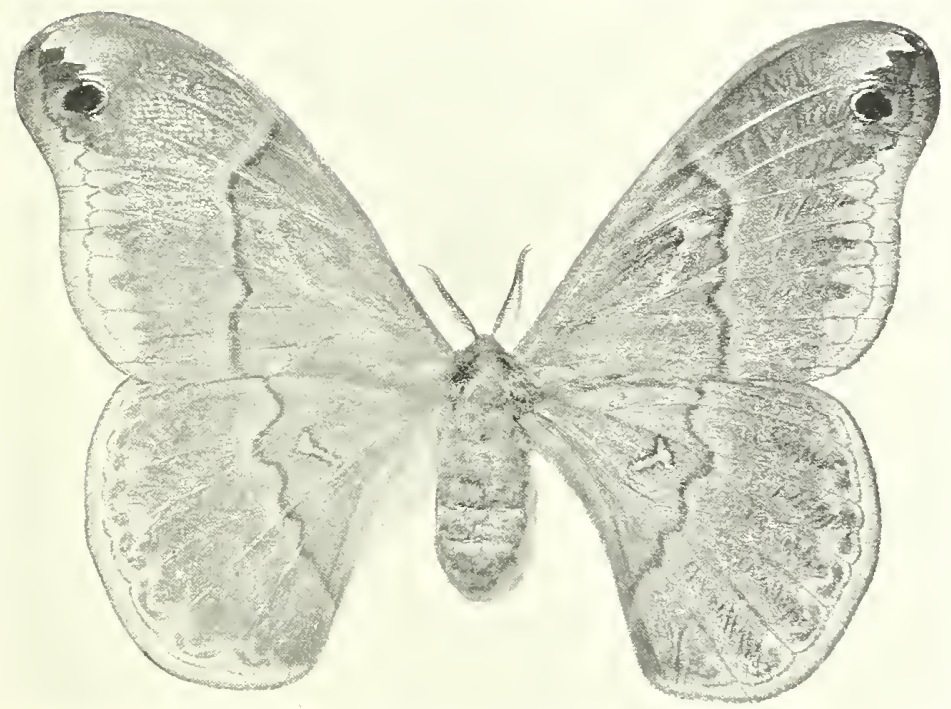

Female Moth.

ATTACUS ANGULIFERA. 

insect, and in preparing specimens for the cabinet the abdomen should be opened from the under side and its contents removed, the space being filled with cotton. Attacrs promethia is a day-flyer: but although such a common insect, it is seldom seen on the wing unless one is assembling the males with a captive female. When following up the scent. the insects do not seem to know fear, and one may gather by hand the specinens hovering about a captive female, almost as readily as he may pick roses in a garden.

One of my brothers had an amusing experience on one of his collecting toums through the comtry where he carried a live female, Attames fromethice fastened in a net to the frame of his bicyele. In wheeling along the road he conld watch the train of eager suitors as they followed his tracks, crossing where he crossed and stopling and circling about where he stopped. Coming to a farmhouse, he went in for a drink of water leaning his wheel against a tree. As the good lady brought out the drink of water he innocently asked her if she ever saw any butterflies in that neighborhood. "No," said she, " they are pretty scarce about here; I don"t know when I have seen one." By this time the train of moths began to arive and flutter about the lawn. "Why." said the old lady, "there is one now, a big one; and there is another and another. I haven't seen so many butterflies before this summer. Why look at them. Did you ever see the like? I never sam so many butterflies before in all my life." Having thanked her for the water, my brother mounted his wheel and ronle away, followed by the flock of " butterHlies," leaving the old lady standing on the lawn and looking after him in open-mouthed wonder.

Attacus angulifera is a moth closely related to the preceding. It is a rare insect in the Northern and Eastem States. but is plentiful in some parts of the South, where the lava feeds on the leaves of the buttonwood. The cocoons spun by this eaterpillar, which closely resembles A. promethiu, also resemble those of that insect, and are attached to the stems in the same manner. They are, however, larger and less firm. The moths hatch in June, and are day-flying insects. The female is a rich tan color, with a black wavy line extending across all the wings and the eye-spot near the tip of the fore wing, similar to A. promethic. The male somewhat resembles the female of A. promethio in the color pattem of its wings, but is of a dark yellowish and ochreous-yellow stippled with dark brown or black. 
The latge and fine moth, Telen polyphemus, is a mative of the eastern half of the l'nited States. and is a familiar object to every one who has male a collection of native lepirloptera. The eggs of the moth, two or three humbled in number, are usually lais singly on the leaves of a valnety of treen, oak heing its farorite food plant, while mapke, elne bireh, cherry, linden and other trees frequently fumish its fleshy light green larva with sustenane. The latra may easily be distinguished from the linvil of Adtides lume, which it elosely resembles, by the seven oblique yellow lines on each side of its abdominal segments, while the larvat of $A$. hum has a lateral yellow stripe. It is a large and hamdsome caterpillar, when fully grown

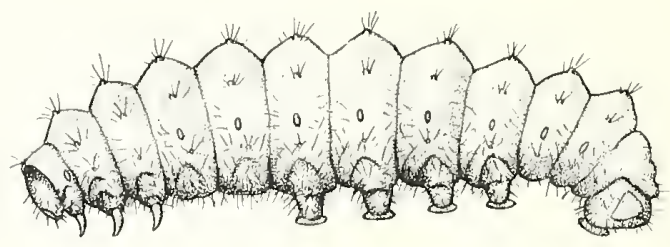

Larva of Telea polyphemus.

measuring three or fom inches in length and thicker than one's thomb, while each of the segments is arlormed with pearl-colored tubereles from which spling silvery hairs. The caterpillar spins its whitish oval coenon in teptember, and passes the winter in the pula

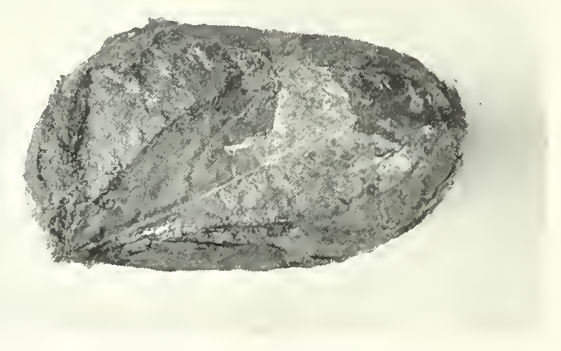

Gocoon of 'Jelea polyphemus.

state. The coeom is momally spun among the leaves still on the tree, ant grenerally falls to the ground with the leaves. The silk is strong, nearly white and of a silvery lustre, and as it is spun in a continnous thear, it may with care he unwound after soaking in war'n water in which has been dissolverl a little baking soda. 'This 


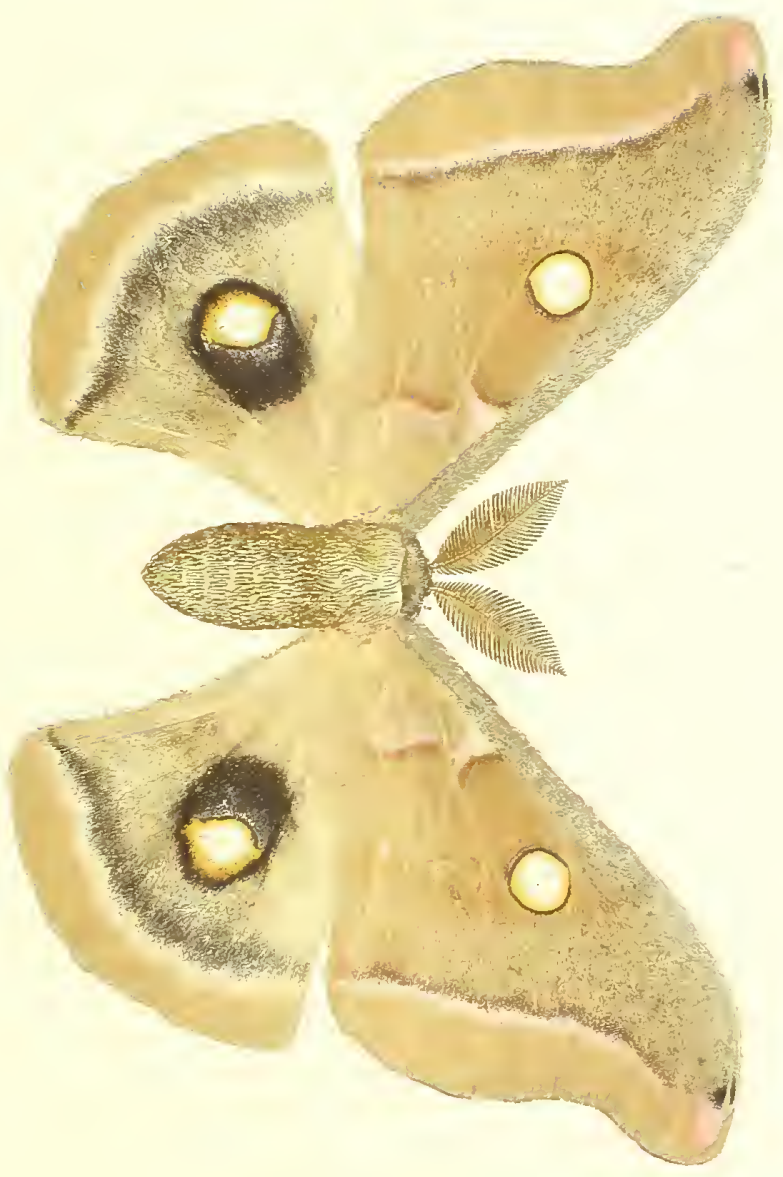





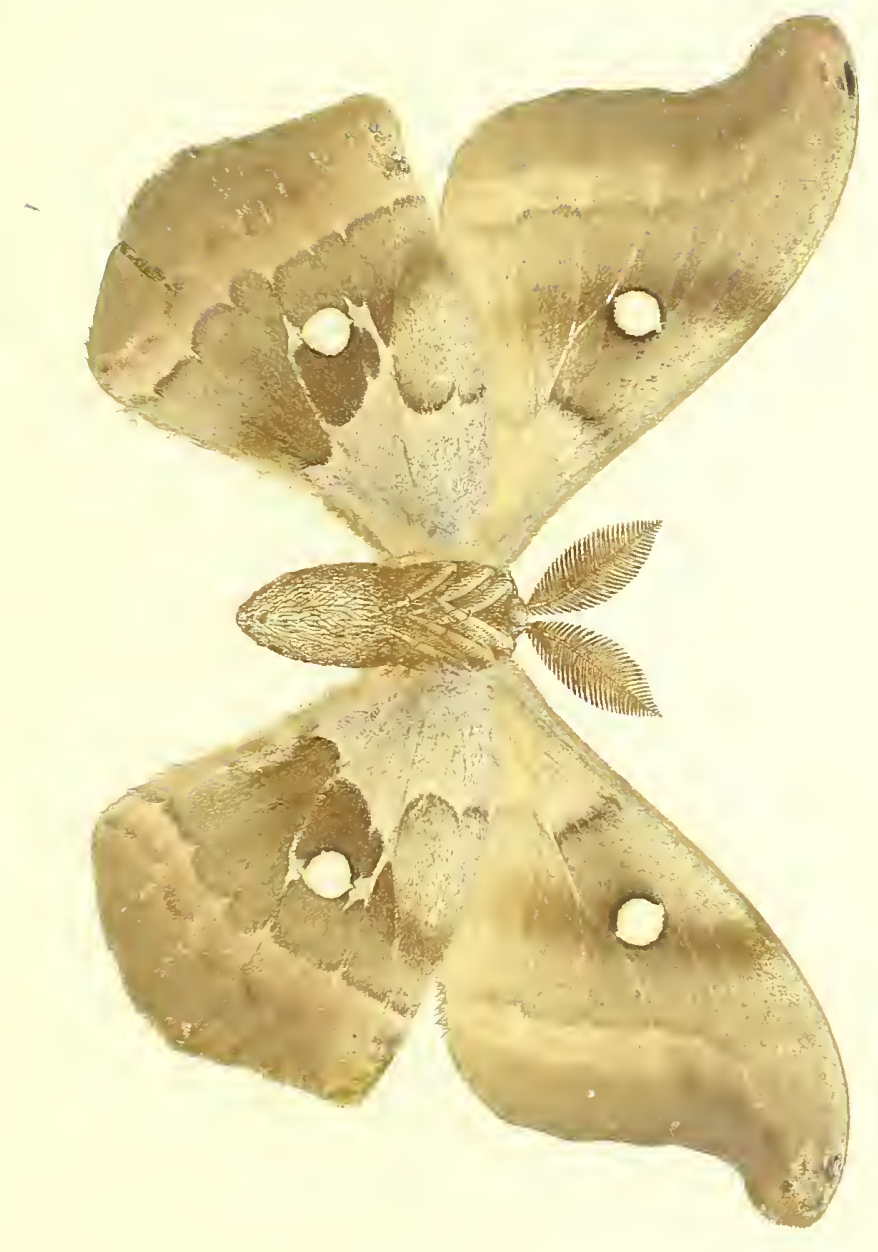



silk has been used for manufueturing into fabries, and although it las not the fineness of the silk of Bombyr mori, it is exceedingly durable and beantiful, and a gament marle from it would probably last a life-time.

Many experiments lave been tried from time to time with the view of making this insect of commercial value as a silk protucer, but thus far, I believe, without success. The greatest difficulty seems to be to unwind the silk fiom the coooons rapidly enough and in a sufficiently large quantity to make the operation financially successful. It seems as if here was a fair field for the inventol. What clothing we might lave if the silk from the eocom of Tren polyphemus conld be unwound. shun and woven into cloth inexpensively. Just think of the undergarments, socks, gloves, ete. we might wear, not to mention the curtains, portières, rugs and carpets that might adorn and bing comfort to oul homes. I believe this will be achieved at no distant day. Is the food plants of this insect aloound almost everywhere where there are forests, the food supply is untimiterl. The eaterpillars are hardy and eould be reared ont of doors in innumeralsle millions with the simplest contrivances; and with simple and efficient methods of manufacture, silk goods should be as cheap as cotton.

It is interesting to watch one of these large eaterpillars spin its cocoon. The spinneret is located just below the jaws, and as he moves his head backward and forward the silken thread is drawn out. It takes about three rays continums labor to complete the coeoon, and when it is nearly tinished the caterpillar gives the whole interior a coating of waterpoof varnish, which when dry malies the cocoon feel hard and firm.

When the moth is about to emerge, a liquid is discharged from a gland located where the montl shonld he, if it had one, which dissolves the substance which binds the threads together, when they are pusleed aside and the insect encalyes from a large round hole in the end of the coenon.

There is considerable variation in the color of the moths. Some are gellowish, some luff. while others have a decided reddish or pinkish tint. 'Tlese latter are fregnently very large and beantiful specimens. Telen polyphemus is a night-flyer and on this aceount although a common insect is rarely seeu untess one knows just where and when to look for it. The males are easily assembled with a caged female, and when the cocoons are hatching in one's attic the males 
outside will sometimes keep "ul, such a fluttering against the windows of the house in their mial desire to get in, that sleep is out of the question.

The smplasingly beautiful Actias lum, with its translueent peagreen wings bortered with purple, is justly esteemed by eollectors as one of the most lovely ereatures the insect worlil affords. When fresh from the cocoon, its downy wings fully expanded and perfect in every detail. it is a delightful creature to look upon, and is familiar to most persons who have lived any time in the country, the long tails of its lind wings and green color malking it easily distinguished from any other insect known to the United States or Canadia. The moths emerge from their cocoons in .June, and may frequently be seen on moonlight nights flying among the upper branches of the forest trees. Being very light they look almost white in the moonlight. They are diffienlt to catch on the wing unless one has a female with which to assemble them, as they fly so high. They usually rest quietly among the foliage in the daytime, and on account of their protective coloring are difficult to fiml.

The eggs of the moth are laid singly on the leaves of the wahut, hickory, birch, chestnut and other forest trees athout the middle of June, and the caterpillars soon hatch. They are dark in color at this stage and covered with hairs. They reach their full size early in September, and are then two and a lialf to three inches long, as thick as one's thumb, and of a translucent green with a yellow stripe extending along each side, a similarly colored band ruming transversely across the back between each of the segments and minature pearl-eolored tubereles along the hack and sides, whieh bear many short, light yellow hairs. This larva closely resembles the Trlea polyphemus larva in shape and size, lut the latter has larger tubereles, the segments are more humped, and it lacks the entinuons yellow stripe on the sides. The larvie spin their thin, brownish cocoons among the leaves, still fresh and green, and when they fall, the coeoons fall with them and are eovered up on the ground by other leaves and by the snow, which protects them from the severe frosts of winter. Many of them are foumd by the moles, skunks, crows and jays and help eke out the scanty rations of these animals during the months of scareity. One may find the coeoons in autumn and early spring by searching among the fallen leaves under the walnut and birch trees. This insect is not very hardy, but may be reared with care from the egg or the caterpillar, although the moths 


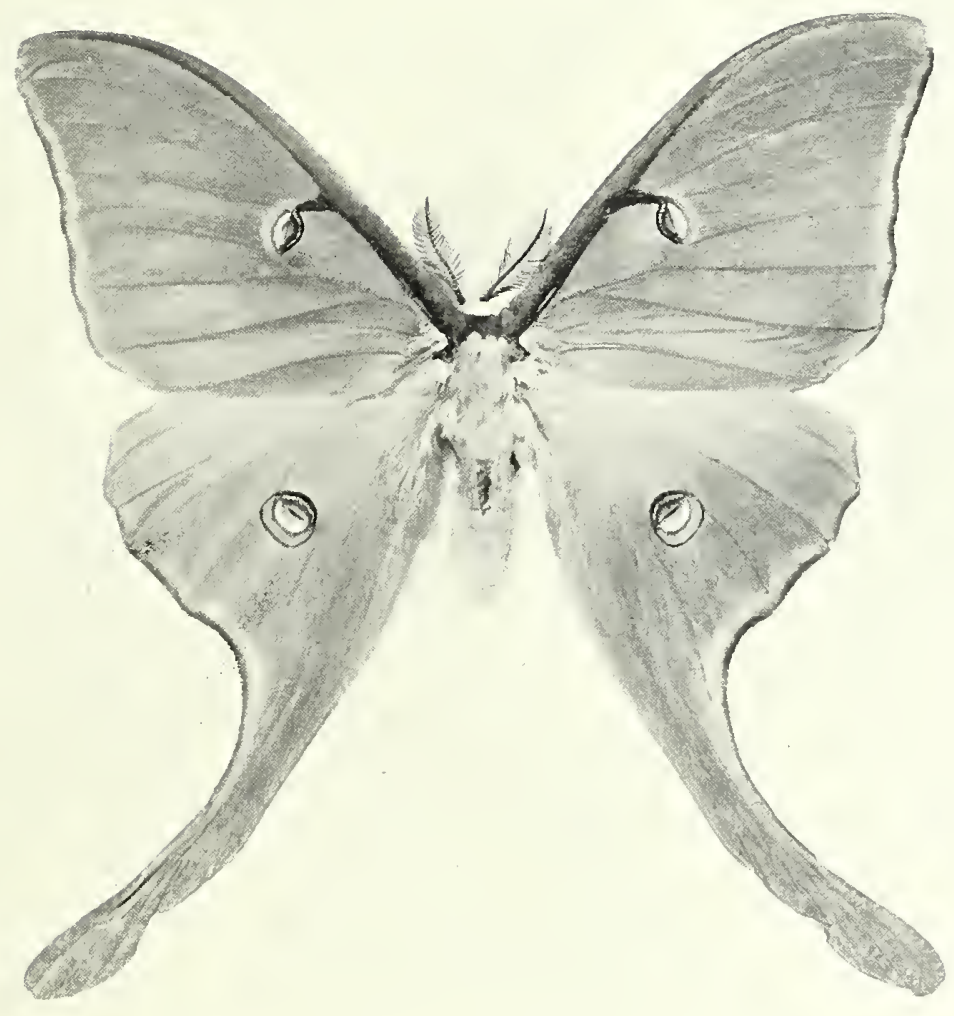

ACTIAS LUNA.

Male. 

are apt to be small in size, as the insect does not seem to thrive well in captivity.

I am in lopes of finding a method of breeding luna moths of good size, but so far the efforts of my brothers and self have resulter in pigmies. This insect is sometines found in great abundance, and I have seen the sidewalk under an eleetric lamp litterer with their wings, the insects attracted to the light having probably been deroured by bats.

Cabinet specimens should be kept out of the light, or they will soon lose their beauty. A good-sized insect of this species will expand five inches. The females are generally of a bluish-green, while the males are more yellowish. The broal band along the upper margin of each fore wing, extending across the thorax, is purplish-brown. On each wing is a transplatent eye-like spot sulroumded by lings of maroon, ochre-yellow and black. 'The body is very downy and cottony-white, and the antenne are ochre-yellow. The insect has a wide range over a large part of the country. Allied species are found in Central Anerica and in Japan and Clina.

The silkworm par excellence (Bombyx mori), domesticated in China at a very early date, was long ago introduced into Europe and later into America, where it is still cultivated to a limited extent. The rearing of the larve and reeling of the silk of this species has not met with the success predicted for silk culture in this country: and although the govermment took up the problem in a scientitic manner at their expcrimental station in the Igricultural 1)epartment in Washington, D. C., after a great many attempts covering several years, the enterprise was finally abandoned. One great obstacle in connection with the successful rearing of this insect in large numbers is the fact that it thrives well only on the mulberry tree (its native food plant) and the osage orange, necessitating the cultivation of these trees ovel large areas. It is also much less hardy than the larve of most of our silk-spinning moths. The insects, too, are very susceptible to several contagious diseases which sometimes carry off lumdreds of thousands in a single night.

The female moth lays three humdred or more eggs, which are round and of a light yellow color, and are usually attached to the paper generally provided for this purpose by a secretion fumished by the moth. The eggs soon begin to turn dark, and the young caterpillar when it makes its escape is dark gray, clothed with long hairs 
which spring from tubereles on its sides and back. With each moult the aterpillar grows lighter, and when fully grown is two inches long, dnll gellowish in color, with a curved hom somewhat resembling that of the havis of at sphinx moth on the posterior end, and the first three segments next the heal very much swollen and wrinklest, The interion of the body is filled langely with the silk glands, extemding one on either side in a loosely-wrinkled tube. These are the glands from which, after the larva is steeper in vinegar, the silk gint so useful to the angler is manufactured. The coeoons are often very leantiful and symmetrical, nsually oval, but sometimes constrieted slightly alwout the middle. They are ordinarily light yellow, though sometimes silvery white, greenish or flesh color.

The moths emerge in ahout three weeks. They are cream colored with two indistinet lines across the fore wings, and is they expand only a little over an inch, are small in proportion to the size of the larvat and the cocoon. Neither male nor female is able to fly, and after leaving the coeoons they pair, the females lay their eggs and soon die.

This insect has been so long under enltivation that several varieties lave been produced which, if found in a wild state, would be considererl distinct species. The original wild stock is not known, luat may yet be found in some of the little-known interior distriets of China or Indlia.

An inseet which is fast becoming well known through the C'nited States and Canda through the efforts of the Massachusetts legislature in distributing pofusely illnstrated literature on the subject, is the Gypens moth, Oenerin or Porthetrie disper, an importation from Enrope. The larva of this moth, to which little in the way of vegetation seems to come amiss, is a most destructive pest, and, but for the efforts of the state, which has aprropriated large sums of money for its extermination, the inseet would doubtless ere this hatve sprear over the whole of the eastern half of Massachusetts. At fresent it is confined to a limited extent of comtry within Middlesex Commy, and it is loped that by persistent effort it may be entirely eradinated. The insect is attimkerl at every stage of its development. About the trunks of trees in infecter distriets bands of burlap are secured, and muler these the larvie are often fouml resting during the rlay, they being night-feerlers. The pupe concealed about stone walls, on fences and tree-trunks and like places, frequently in immense numbers, are destroyed when foumd. The egg clusters are 


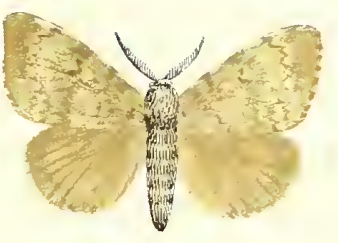

MALE

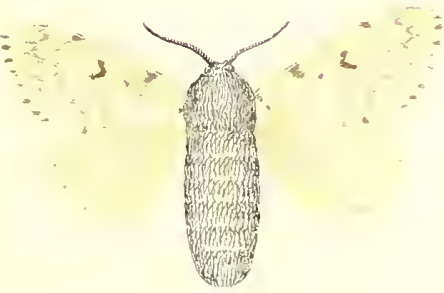

FEMALE 

gathered and burner or treated with a solution which destroys their life. Whole areas of forest and serub land have been cleared and burned over to annihilate the pest. The work of the Board for the extermination of this pest lias met with a good deal of adrerse critieism, but that its labor of keeping in check this foreign army of invasion las been tholoughly performed, is shown by the fat that in many places where most abundant a few years ago it is now a very scarte insect. In fact one maty walk for miles through parts of the infesterl area and not see a sign of its presence.

The male moth is much smaller than his mate and can fly. while the female, although provided with wings, cannot use them in flight. The distribution of the insect, therefore, even if unrestrieted, would be slow. The eggs are laid in clusters. usually on the bats of a tree, although the moth does not seen to be particular in this respect. The clusters are coveled with hairs from the abromen of the female and being ochre yellow in color are reatily seen. The larva is brown and is thielily covered with stiff hairs. while red and blue tubercles adorn its back.

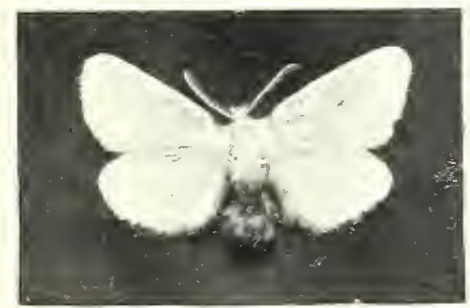

Porthesia chrysorrhoa.

Another importation from Europe which has also found a foothold in eastem Massachusetts, although not nealy so destructive as the Gypsy moth, is the Brown-tail moth, Porthesid chrysorlewa. 'The moth is ereamy white, with a white body tipped at the end of the abdomen with a tuft of hrown hairs, from which the insect derives its common name. The lanva is dark brown or black, with reddish hairs covering the body except on the sides. Where there is a row of small tubercles from which spring white hairs. There are several small scarlet warts on the bakk. This insect is a good deal of a pest where abundant, as it devours the leaves of several of our fruit and shade trees and measures may have to be taken to provent its increase and spread. 
I $111 m$ mer of the following stont-hodied, hairy motls belong to the family Natolouta. Sine of them resemble the Noctuids, both in the pupa and perfect state, and may easily be mistaken for them. 'The latrac, which often bear humps, tubereles and spines in many of the species, have but four pairs of ahdominal legs used in erawling, the last pair being prolongerl into tails or are held above the supporting twigs while at rest. Some of the larve ane naked and others sparingly elothed with soft hairs. They feed on the leaves of trees and shruls. often in great numbers, and their transformation usually takes place beneath the groumd.

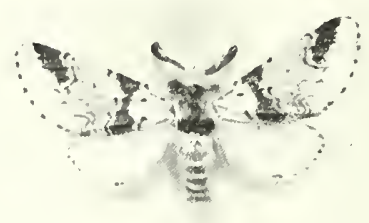

Gerura borealis.

forma lonerelis is a whitish moth, markerl with brown hands across the npler wings, and is interesting from its peculialy shaped

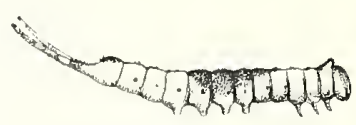

Larva of Cerura borealis.

larva, which has a forked polongation or tail arlated fom the last fativ of ahlominal legs. When distumbed it pushes out from the end of this forked tail two fleshy orange-eolored filaments. which it bends over its back or sides as if to protect itself. 'This larva is maked, is green and purplish in colom, and feeds on the pophar and chokeelerry : its rolor is protective, and it looks while feeding on a leaf a dried and withered part of it.

Chosters of a smooth, bluish, yellow and black-striped larva, with the head and a hump on the posterior end of the body, orange-red, 
may often be seen langing to the stems and leaves of the oak in September. This is the larva of Erlema albifrons and is sometimes

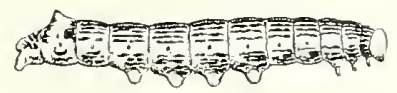

Larva of Edema albifrons.

abundant enough to do considerable damage to the trees. When not feeding, and especially if distmberl, the caterpillars bend the lead

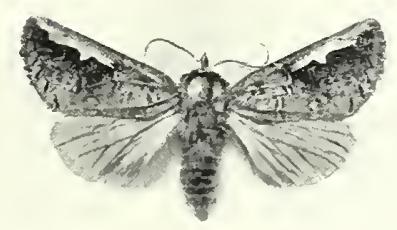

Glema albifrons.

and rear end of the borly over the back. The perfect insect has hrown upper wings with a whitish land along the upper margin, and light yellowish-hrown lower wings.

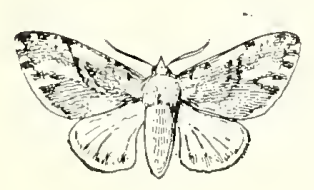

Coelonasys unicornis.

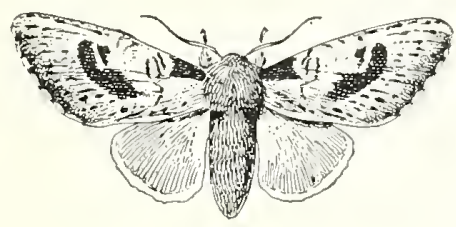

Gololasys biguttata.

A curionsly lumped caterpillar is the larva of Celodesys, of which we have several species. Chelodusys mimmis is buff-gray,

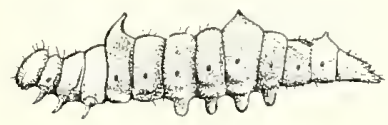

Larva of Crelodasys.

with darker markings, and Combelusys biguttute is gray with brown markings and light brown lind wings. 
A elosely related species is Nerise lidentuta, a little moth which is rather rare. The mper half of the upler wings is brown with an meven dark hown line ruming from base to margin. Below this is

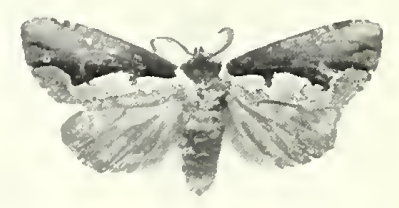

Nerice bidentata.

a white area gradnally shating into light brown. The lower wings are light liown.

Amother entously humper caterpillar is the larva of Edemasia continne. 'The head and a hump on its lack is red, while the body

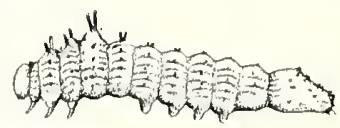

Inarva of Gutemasia conchma.

is stripeed with blakk, yellow and white lines and supports a few bark spines. This aterpillar is sometimes to be seen in elusters on

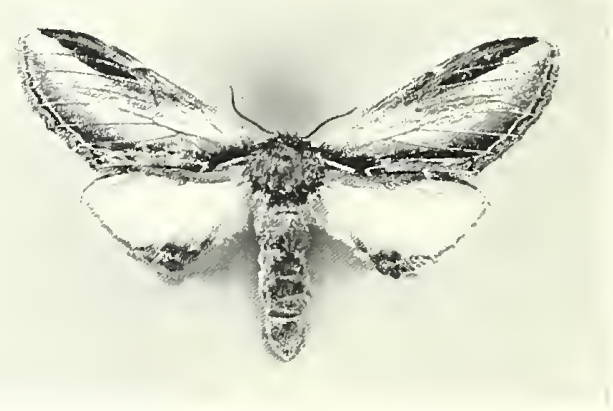

Plieosia rimosa.

the apple-trees. where. if mmolested, it is capable of stripping the branches bare of leaves. It also feeds on the cherry and plum. The 
coconn is made under leares in August or Septemler, and the perfect insect comes forth in June or July of the following year. The moth is light brown and gray and has a dark brown band along the lower margin of the unper wings. It expands something over an inch.

Pheosin rimose is a gray, hown and yellowish-white moth oecasionally to be seen about electric lights. It looks and flies a good deal like a moctuirl.

A moth whieh curls its aldomen ul, in a curious manner when at rest is Aputelodes torrefincte. In this position it would scarcely be

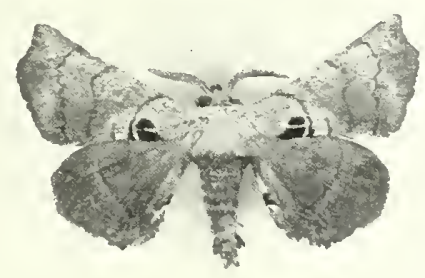

Apateloules torrefuctu.

taken for a moth at all unless closely examined. The fore wings are glay, with a dark hown shot near the base. The lower wings are light pinkish-brown. Both sets of wings have faint lines crossing thenl.

Great numbers of a black and yellow-striped larvat sparingly furnished with soft whitish lairs may be seen in 1 ugust and september on the apple and cherry. and also the bireh and other forest trees. completely striping the branches of their leatres. So numerons are they and sometimes congregated in such masses that the handes bend with their weight. These eaterpillaw bend the head and tail

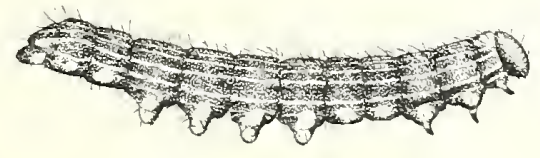

Laxva of Datana.

up over the body when disturled and rest on the fom forward pairs of abdominal legs. They are the lanve of Datome. The caterpillars 
deserud a few inclues into the gromed in the antumn, where ther remain in a chryalis state till the following July. Ou best-known

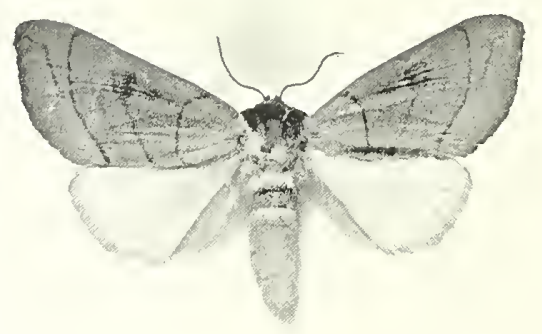

I)tana ministra.

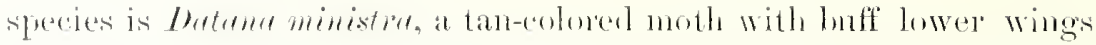

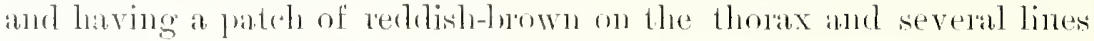
of the simne color crossing the fore wings.

1 genms of moths of medium size, interesting from their gay colon's and the habits and shapes of the larve is limucolles. These laves are slug-like creatures, and wonld lardly be taken for caterpillaws at all ly the noviee. The body is short and thick, high in the mickle and flat beneath. The hearl is encealed beneath the forward part of the body, and both the true legs and protegs are

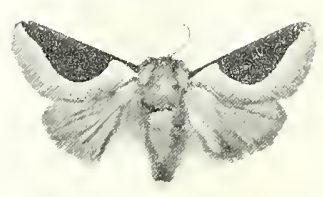

Limacodes scapha.

scareely discernible. The mimal aulnering elosely to the leaf (ol twig ujon which it rests has mueh of the gliding motion of the slugs. Some of these larve are naked, while others are adomed with branching spines or fleshy filaments. Some of the eaterpillars 
are gayly colored. When mature they spin a tough oval or nearly spherical cocoon attached to the twigs of the food plint, oak, walnut, birch and other forest trees fumishing them with food. The moth emerges from the cocoon by jusling off one end, leaving the side attached like a lialf-splierical lid.

Limacodes somplea is a prettily manked little moth expanding abont an inch. The body and lower wings being einnamon-brown, and the upper wings having a rich reddish-brown patel eovering most of the upper part of the wing, edgerl with silver beneatl. The rest of the wing is light brown. The larra is green, without spines, short, thiek and high in the mindale. It feeds on the oak.

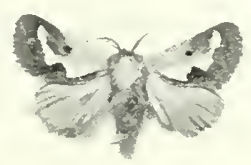

Limacoles querceta.

Another prettily marked insect is Limecoles prepeete. It is reddish-brown with a small dot of dark hrown in each fore wing, and a broal, irregular patch of light green extending from near the lower margin next the body diagonally aterosis the wings to near the tip.

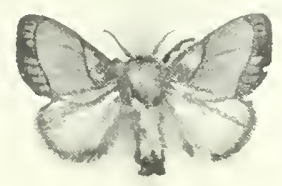

Parasia fraterna.

The caterpillar lives on the oak and willow, is yellow and purple in color, and has a number of branching, pointerl filanents which spring from its back and sides. 'Tle motl makes its alpeanance in July, and often comes into our rooms at night attrated by the light. It is a rapid flyer for so small a moth, its short wings lumming with the rapiclity of their motion. 


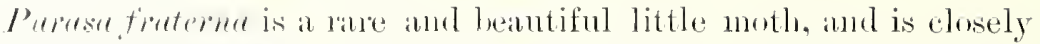
relaterl to Limuendes. The rluper wings have a wirle, bright-green band crossing them, with a brown margin and a brown pateh next the body. The ablomen and lower wings are light yellowish-brown, and the thomax is green. I have taken this insect on luat two or three accasions with a lighted lamp in Massachusets, and know nothing of its life history.

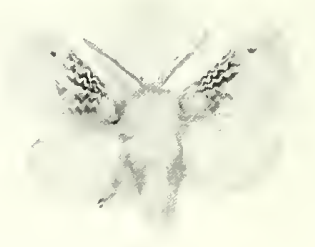

Lagor crispata.

To the genus Layou belong some very woolly moths which go by the alpnopniate name of flammel moths. Gur common species, Latyoa crispute, is of a light yellow or light huff with crinkled black and

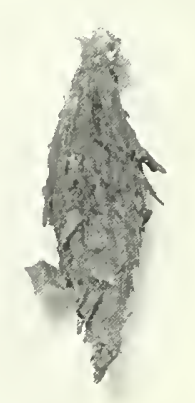

Case of the Lvergreen bag Worm.

light lnown hatiss on the fore wings. The looly is very downy, and When at rest with the wings folded the creature looks like a bit of wool. The larva, which is also very woolly, feeds on the blackloerry,

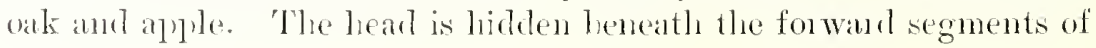


the body and the legs are so short as to suggest the larra of the Limacodes. The cocoon is formed of the hairs of the caterpillar closely woven with silk.

In Thyridopteryx ephemeraformis or the evergreen bag worm. the larva constructs a bag or ease of silk and pieces of the leaves of its food plant, which it carries from place to place as it feeds, and in which it resides luring its caterpillar state. The larva lives on the led cerlit and the arbor-vite, and the pieces of the leaves are latid lengthwise of its case or bag. The female moth is wingless and grublike, and nevel leaves the case, in which it transforms into a pupa after laving elosed up both ends with silk. The male is provided with wings which support it in flight. Its body is long and tapering and its antennce are pectinater. Several species of this genus are natives of this country.

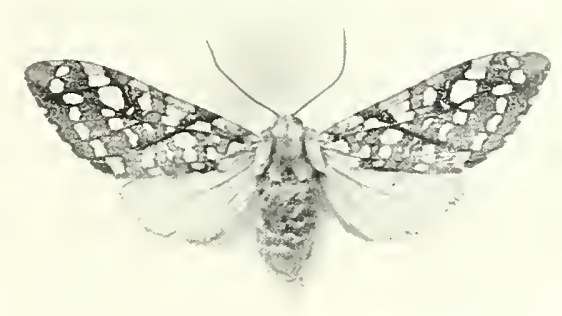

Halisidota caryx.

An insect sometimes very common and doing considerable damage in the Eastern States to lickory, elm, beach, aprle and other trees is the hickory-tussock moth, Mulisedote curyce. The larva is a luetty caterpillar, an inch and a half long when nature in September. The head, feet and belly are black, and the hody is covered with slreading tufts of hairs. white on the sides, with a crest of black tufts along the middle of the back, and long white lairs growing forward over the head. There are also two pairs of tufts of long black hairs placed near either end of the borly with a single pair of white tufts near the posterior end. The larva makes an oval graty cocoon composed largely of its own hair's held together with silken threads. This is usually hidden away beneatli stones, in the chinks of bark. etc. The moth makes its appearance in June. Its wings are ochre 
fellow and seem to be thinly covered with scales, rendering them semi-transparent. Several rows of whitish, silvery spots crosis the fore wings and between them is a tinestiple of brown tots. We

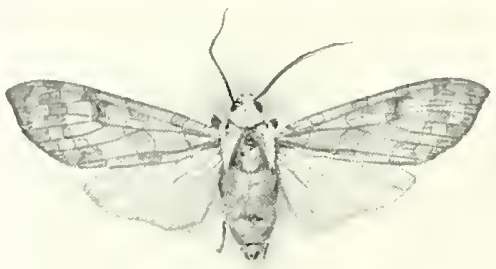

Halisidota tessellata.

have other species of tussock moths which closely resemble the foregoing, both in the larval and perfect state.

Orgyine Teurostigme is interesting from the fact that the female is a wingless, grub-like creature, looking little like her mate which, although plain grayish-brown in color, has broal wings and can fly.

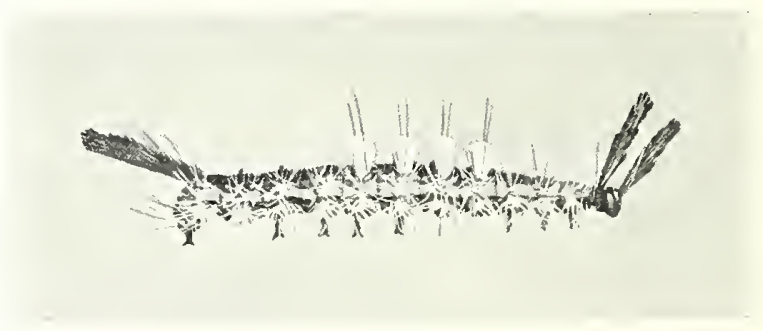

Larva of Urgyia lencostigna.

'The caterpillar is one of our handsomest, being striped with yellow, bown, green and lilac, sparsely dothed with white hairs on the sirles with two lomg plumes of brown hairs next the head, a similar phme on the posterion end of the boly and four short, thick, white puffs on the back. Its head is red, and there are two red warts near the tail. The insect feeds on apple, sometimes doing a good deal of damage, spins a thin cocoon frequently on the tree trunk, and upon emerging, the fomale lays hereggs on the top of the cocoon, cover- 
ing them with a frothy substance which, on drying, makes a white crust.

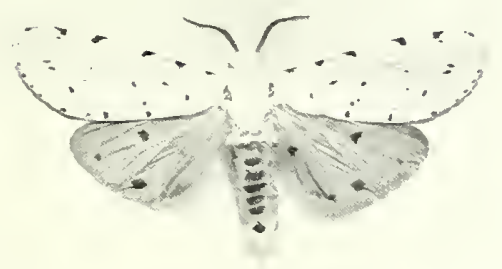

Lenearetia acrea.

Sometimes seen in numbers in . June is the salt-mash moth,

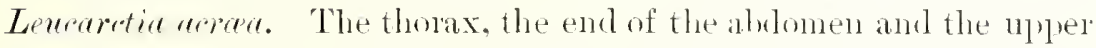
wings of the male moth are white, while the abchomen and the lower wings are yellowish-tan eolor. Both sets of wings are sprinkled with black dots, ame the abdomen has two rows of small dots on each side and a row of large liack spots on the back. The female moth differs in color from the male in that the lower wings are white insteal of tan. The harva of this moth, which is wirlely distributed, is frequently seen in large numbers feeding on the coarse lowland grass, not only of the sea-coast. hut in the interior of the country. It will also attack other plants. and is eapable of doing a great deal of damage. When full grown it is nearly two inches long. covered

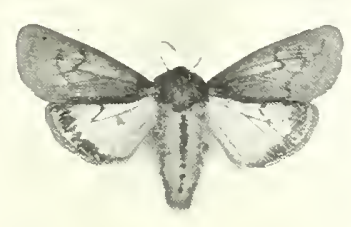

Plragmatobia rubricosa.

with long dark bown hairs on the back and lighter hais on the sides. The spiricles along the sides are white and the skin of the caterpillar is yellowish. In the fall the caterpillar conceals itself 
among the lower garas stems or under stones, and there makes its losiry lowwn coeom, in which it passes the winter in an chrysalis state.

1 pleasingly-tinter little moth is Phommatolin mbionse. The npler wings and thorax are pinkish-brown, the lower wings reddishpink with brown mangins, and the aldomen is red with a row of small buwn dots an eithere side, with anothere low down the back. The wings ane so thinly chotherl with seales as to be alnost transfarent. The lan rat is nuknown to me.

An insert well known to alonest every one is the bown and back hairy catempillan covered with stiff short bistles all about the

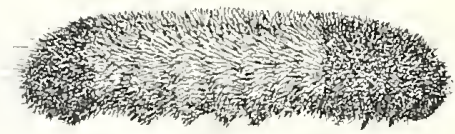

Larva of l'yruaretia isabella.

same length, which bolls itself into a romurl latl when disturberl. This creature feeds on a variety of herdmerons plants, and may be seen in the fall activoly engaged in seeking a suitalle place for its winter liberation; for, mulike the larve of most lepiclopterous insects it passes the winter in the caterpillar state and may sometines be fomm on mild tays in the winter crawling orer the smow.

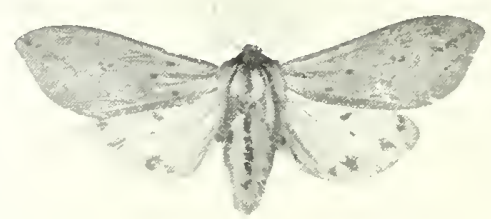

Pyrrliarctia istbella.

As soon as vegetation starts in the spring it begins feeding, and makes its laily poom moler boards, stones and the like in $\Lambda_{\text {pril or }}$ Many, whence it emerges a moth in Jume or July. This moth is

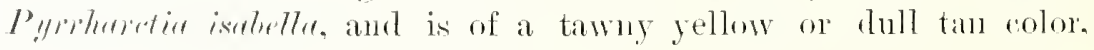
hatring a number of brownisla spots on its wings and body. 
The Aretians are a genus of moths represented in this comtry ly several exceedingly beantiful forms. The species are very rariable. and on this account have causerl considerable confusion. The antenne are usually featherer in the males and simple in the females. The larva is covered with stiff sharp-pointed hairs. 'The
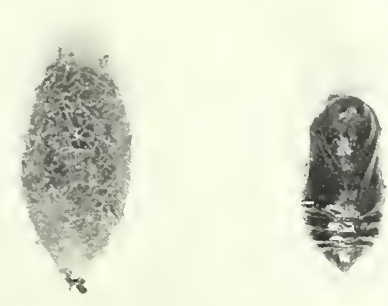

Cocoon ant pupa of an Aretian.

coeon is oval, loosely constructer of the hairs of the caterpillar interworen with a few threarls of silk. The chrysalis is stout, smooth, and dark brown in color. The moths of this genus come readily to a lnight light. and a collector in the comtry will often find them flying about his room on warm stmmer evenings. They lave a habit of feigning death when captured. Several of the species give off a strong orlor when hambled, which is probably a protection to the insect from its enemies.

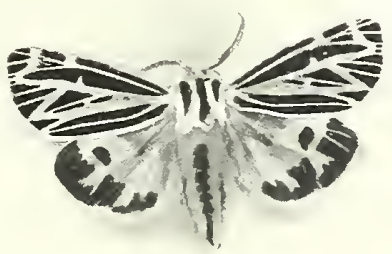

Aretia nais.

Arctin me is a widely distributed insect. leing found orer the whole of the United States ant the lower part of Canarla. This insect, according to Edwards, has, on account of its rariation receired 
no less than nine different names. The wings are usually an inch and a half in expanse and are of a pale yellow, pinkish near the base of the lower wings, and striped on the forward gair by broad binds of black with triangular black spots near the outer margin. The lower wings also have several black spots. These spots and bankls sometimes cover almost the entire surface, giving the moth a very different alperaranee. The abdomen is usually flesh color with a band of hata on each side and one on the top. The caterpillar lives on the diandelion. Its hairs are black on the back, and brown (m) the sides.

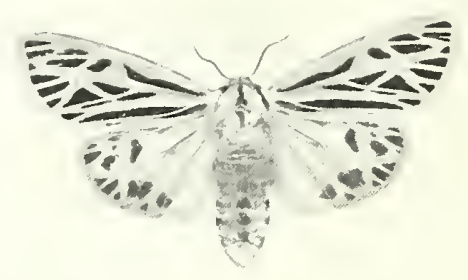

Aretia arge.

One of the most common surecies of this genus is Aintia arge. The generat color is a flesh tint, leing intensitied to redelish along

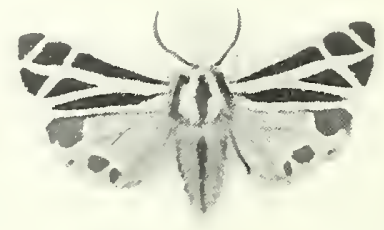

Mctiat phalerata.

the moter margins of the lower wings. Narrow triangular black spots and long black stripes anlorn the upper wings, with several blark spots on the lower wings. I row of liack spots extends along each side of the abdomen and one row down the back. This insect 
expands nearly two inches and makes its appeatance in June and July. The caterpillar is dark gray, sometimes almost black, and is thinly clothed with cluster's of spreading black hairs which spring from dark colored warts. The larve live on the plantain.

Another common species is tictia pheterata. The thorax and upper wings are yellowish-huff with broad black stripes and triangular spots, and the abdomen and lower wings are reddish-pink with black spots and markings.

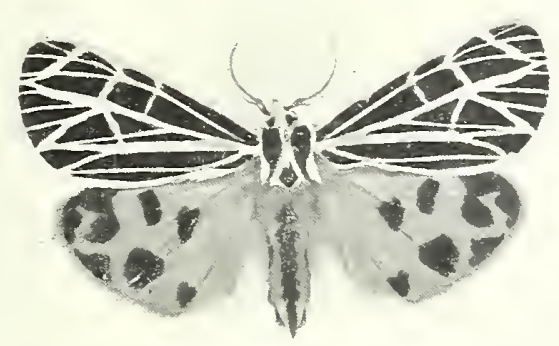

Aretia virgo.

Our largest and most beautiful species of this genus is tretia virgo. The upper wings are flesh color marked with broad stripes of black, and the lower wings are vermilion red and deep reddish-pink at the base with large black spots. The thorax is the color of the upper wings, with three black splashes, and the abdomen is the color of the lower wings with a black band on each side and on the back. I have never found this insect abundant but have taken it in Angust with a lighted lamp in Massachusetts and in northern Ohio. The insect expands two and one-half inches. The caterpillar is brown. covered with brown hairs, is two and a half inches long when fully grown, and feeds on pigweed. doek and plantain.

The common snow-white miller, Arctia virginica, has a wicle distribution. The wings are pure white with one or two small dots of black. while the abdomen has the customary black sjots of the genus on the sides and back with a yellow stripe on each side. The caterpillar of this moth is the "yellow hear," which is a common pest in our vegetable gardens, derouring almost everything in the way of herbaceous plants it finds. Its body is covered with long yellow or 
tan colored latirs, and it has an interrupted stripe of brown on either side and a bown band between each of the segments. The insect passes the winter in its hairy cocoon, and in the following June appear's as at motl.

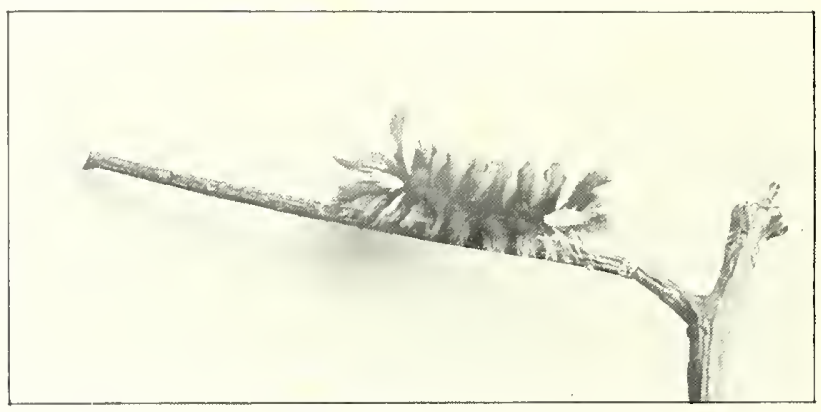

Larva of Cyenia egel.

On the milkweed may often be seen numbers of little caterpillars covered with tufts of black, white and orange hairs. 'These are the larlequin caterpillars, and are the larve of a plain little blue-gray moth, Cycnia egel, which makes its alpearance the latter part of Inne, after having passed the winter in the pupa state in its oval hairy eocoon. The aldomen of the moth is yellow alove, with a row of black dots down the back, resembling the Arotions.

Utetheisie belle is a very beautiful moth, and is widely distributed over this country. Its halits are similar to a following species, the sollier moth, and it is often found in low grassy districts in consideralle numbers, taking to wing readily when disturbed. When handlert it exudes an oily substance with a peculiar odor, and remains lerfectly still, as if dead, soon, however, taking wing if not further nolesterl. These habits, combined with a probably very bitter taste, have doubtless preserved this gayly colored little creature from extinction. The larva is one and a half inches long, and is yellow and white in color sprinkled with black dots. It feeds on herbaceous lowland plants.

The anchor moth, Callimorplea intermpto marginata, is a rather rare moth, and is about the same size and marked with brown similar to the soldier moth, except that it is yellowish where the other species is white. 

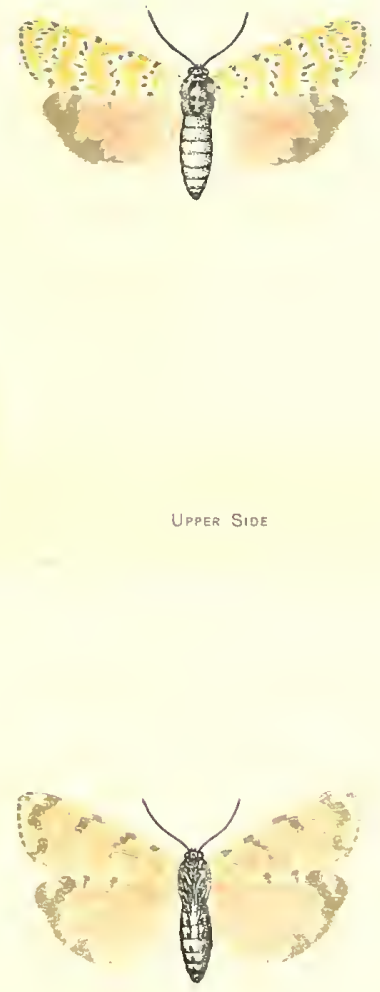

The soldier moth, Callimompha lecontei, is a common species to he found among rank grass or hushes near brooks or swamps in June and July. When distubed it flies a short distance and quickly

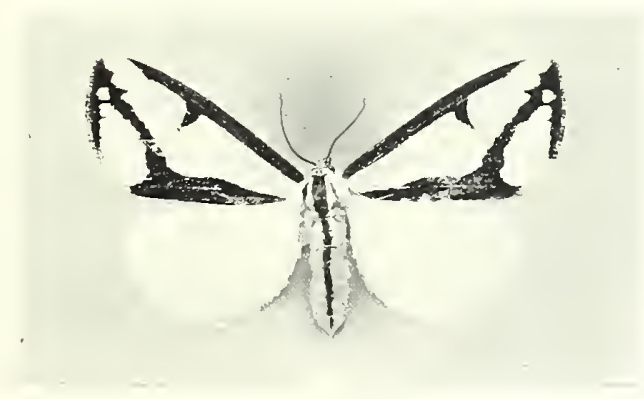

Callimorpha lecontei.

hicles away among the grass or shrubs. This insect is rarely seen singly, and often while walking among the grass of low land I have started half-atdozen of these moths from their hiding places. 'The wings are creamy white marked with dark brown, the head is yellowish, and a brown stripe extends down the back, the rest of the body being creany white. In some specimens the brown markings of the fore wings cover nearly the whole surface, leaving but a few white patches. The larve are thinly clothed with hairs, and are brown in color with yellow stripes. They are night-feeders on herbaceous plants, hidling by day.

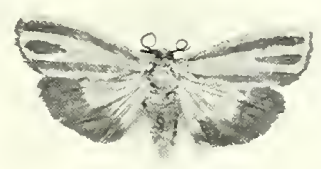

Ilypoprepiat miniata.

A beautiful little moth which sometimes comes to the lamp of the collector is the striped footman, Iypoprepin minicte. It is deep scarlet with three dull brown stripes ruming lengthwise of the upper wings and a broul border of the same color along the margin of the lower wings. The dark brown spiny larva feeds upon lichens, and makes a thin silken cocoon. The moth appears early in June. 
Another suecies closely related to the foregoing and easily mistaken for it is Mypoprepid furose. This moth is somewhat smaller than Ilypopnerpin miniata and may be distinguished from it by the color of the wings, which are yellow and led.

\section{ZYGLNIDE.}

In the family Zyygrmidr, the species lave pominent heads, long namow wings thinly covered with seales, leaving naked spots in some siecies. Some of the members of this family are atorned with gaty colors, and a large number are diumal in their habits, rifling the flowers of their sweets in the hot sunshine. 'The larva is short, thick, and usually adorned with small tubereles. Many of the species are hairy, others naked. Most of them spin silken cocoons, while others utilize the hairs of their coat for a covering for the pupa, binding them together with a few silken threals. Others again make no cocoon whatever. 'The pupa is usually short and stout-bodied.

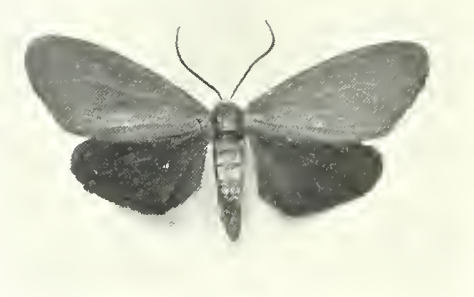

Stemucha virgures.

Ctemulur virginice may be seen on the white clusters of elder blossoms during the sumy hours. It is not timid and is slow to take flight. The hear and sides of the thorax aie orange, the fore wings are smoky-brown, the hind wings bluish-black, and the body is deep purplish-blue. The wings expand two inches or over. The larva is hairy and feeds on grasses. It constructs a thin hairy cocoon.

$\Lambda$ very long and natrow-winged species is Lycomorphe pholus. This inseet expands a little over an inch; in color the shoulder covers and base of both pairs of wings are orange, the rest of the insect being bluish-black. This moth flies only in the daytime, and may frequently be seen extracting the honey from the goldenrod by 
the roadside. The hairy greenish larva feets on lichens growing on stones, and makes a thin silken cocoon.

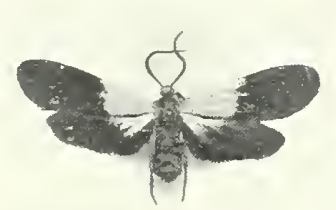

Iycomorpha pholus.

A prettily colored moth is Embryas grute. The thorax and fore wings are white, with brown, pinkish-l,rown and greenish-brown markings, while the abdomen and lower wings are yellowish-louff

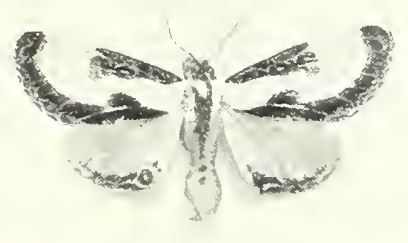

Eulryas grata.

with markings of brown and pinkish-brown. This insect expands alout two inches. The caterpillar feeds on the leaves of the Virginia ereeper and the grape. It is a peculiar looking creature, being blunt at the posterior end and crossed by numeroms lohish and orange lands and fine black lines and spots. The transformations ale pissed in the ground.

Another species, differing greatly in the perfect insect but very similar in the larval state to the foregoing, is Alypin octomuculata. This insect expands something over an inch, and is black with the exception of two large yellow spots on each of the fore wings, two large white spots on each of the hind wings, the shoulder covers (which are yellow), and tufts of reddish-orange hairs on the legs. This moth is an active creatme. flying about in the sumshine, sud- 
denly disalpeatring and as sudfenly returning. It is very common in some gatrts of the conntry. The larva is banded with white and olange and with narrow liate lines and rows of black dots. This species has dight black lines to anch segment, while the precerling

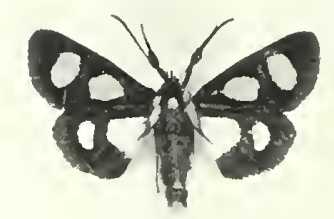

Ilyuia octomaculata.

has lut six. It feeds on the leaves of the grape and Virginia creeper, and transforms into a puln in an earthen eavity beneath the surface of the gromole. There are usually two hroots in a seasom, one conning forth in bune and another in Angust and september.

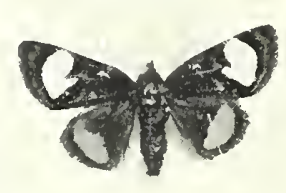

Isychomorpha epinenis.

Pxychomonplow epimenis I have found a lather rare little moth, although I have heard of its heing abmulant in some parts of the comblty. The insect is lilack, with a large yellowish-white spot on eath fore wing and a large brick-red spot on each hind wing. It expruds about an inch. The caterpillar feets on the grape and Virginia creaper, drawing the ents of the young shoots together with silken theats. In shile it resembles the foregoing, lunt has a bluish andentance; being banted with black and white lines. It transforms in the ground. 


\section{EGEPIDE.}

Glexs-uings.

The moths helonging to the family Eggerilce are rather small, and are readily distinguished from all other moths by their resemblance to bees and wasps. They have narow, mostly transparent wings, long bodies, with a fan-shaped tuft of hairs at the posterion end, and spindle-shaped antenne. Most of the species are gayly colored and all are diurnal in their habits. The larve are boress in the stems and roots of trees and shrubs, and do a great deal of damage to some of our cultivated fruit trees. 'They are glub-like, whitish creatures with brown lieads. Some kinds are sparsely covered with fine hairs. The transformations nsually take place in the excavations made by the larva, where a rude cocoon is constructed by cementing together fragments of wood. The pupa is amed with minute spines on its abdominal lings, and when about to break the shell makes its way out of the coooon and along the passage to the opening previously made ly the caterpillar. Were the moth escapes, often leaving the empty shell potmoling from the hole.

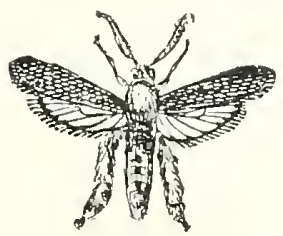

Melittia euenrbite.

Melittid rumplite is our largest native species of this gronp, and expands ahout an inch and a half. 'The npper wings are hlack, the lower ones transparent, edged with a fringe of long hair-like scales. The abclomen is orange with a few lolack dots, and the posterior pair of legs have long orange and hack hairs. The larra infests the squash, cueumber and melon, living in the interior of the vine and devouring its sulstance.

Another species familiar to cultivators of preach and plum trees from the destruction caused by the lava is Fyerid exitiosa. The male and female moths differ greatly in size and general appearance. The male has all four wings transparent, the veins and margins being steel blue. The bouly is also blue, with a yellow tuft at the extremity. In the female moth the fore wings are dark blue and opaque, while the hind wings are transparent, and the abdomen is 
crossed lyy a broud band of orange. The larva feeds on the inner lark and yomng wood of peach and phum trees, infesting them

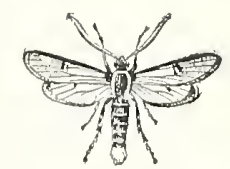

Tigeria exitiosir. Male.

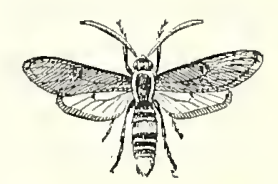

Egeria exitiosa. Female.

especially near the gromul. So destructive is this pest in some regions as to have caused the alandomment of peach growing.

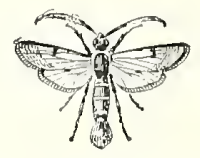

Egeria tipuliforme.

The currant horer, sigerid tipuliforme, is scarcely less destruetive than the preceding, and, as its name implies, the larva bores in the stens of the currant. The larva feeds on the pith of the plants, ansing the leaves to tum yellow and eventually the plant to die. The moth is smaller than the preceding, expanding about threequarters of an inch, is blue-black in color, the wings being transprarent, with a colpery colored bar at the dips of the forward pair. The shoulder covers and three lines arross the abromen are yellow. The moth makes its alpearance in June.

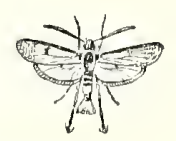

Egeria ryri.

I small species, whose larva bores under the lark and in the young woor of the pear tree, is Algeria pyri. The inseet expands lialf an inch. Its general color is pupplish-black above and yellow beneath; lout the wings are transparent, with a band of eopper-brown at the tips of the forward pair, and the borly is erossed with two narrow lines and one broad band of yeilow, while the fam-shaped tuft of haims at the end of the abdomen is yellow. 
SPHINGIDE.

Dusk-flyers.

The interesting group of moths that come under this head have long been favorites with collectors. Their trim, graceful shapes, the pleasing tints and large size of many of the species, combined with the grotesque attitudes assumed by the larve, make them oinjects of unusual interest. The name "Sphinx moths" was given to the group by Linneus on account of a fanciful resemblance which the

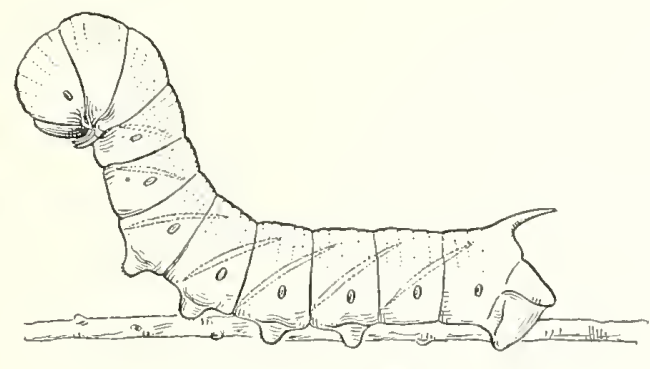

Larva of Sphinx Moth.

larve bear while at rest to the fabled Sphinx. Clasping the twig with the posterior feet the caterpillar raises the forward part of the body and remains in this attitude sometimes for hours. These insects also go by the common name of Humming-bird moths, from the habit of the insects, which while poised on rapidly vibrating wings extract the honey from the flowers. Hawk moths, too, is a name given this group, probably from the strong, direct flight of the insects.

These moths have powerful, long, narrow wings, particularly the upper pair, and stout spindle-shaped bodies. The antenne are stout, thickened in the middle and usually supplied with a enrved hook at the tip. The tongue is often very long, although in some species it is short. The eyes are large and prominent. In one group the wings are transparent, resembling in this respect the Egeriadx. They have strong, well-developed legs. Most of the species fly only at dusk of morning and evening, while others fly late into the night, and a few only in the daytime in the hot sunshine. The larve are usually smooth, naked caterpillars, green in color, with oblique light stripes along the sides, and supplied with a sharp eurved horn on the top of the next to the last segment. In some species this caudal 
hom is to be fornd only in the young caterlillins, an eye-like tubercle taking its place in the more mature larva. That this horm is of any use to the caterpillar I have yet to learn. It may be the survival from its ancestors of a sting; but if such is the ease it has entirely lost its value as a weapon of defenee. The transformations usmally take plaee a few inehes beneath the surface of the ground. A few species make rude cocoons by drawing about themselves leaves and twigs on the ground under their fond plant, and fastening
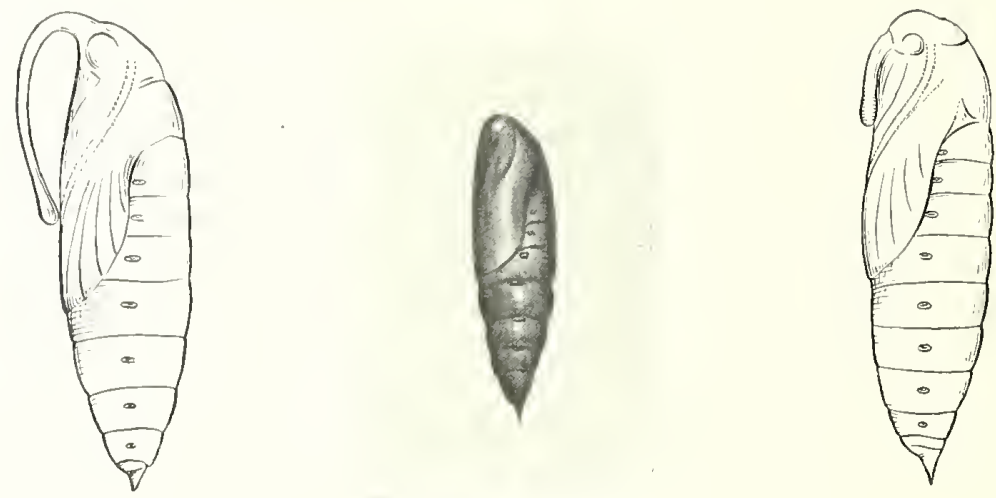

Pupe of Sphinx Moths.

them together with a few silken threads. They usually pass the winter in a jula state. The chrysalis in some species is furnished with a long tongue-case which stands ont from the body and is often compared to the handle of a jug.

Anong the clear-wing sphinxes, our most common speeies is Hemaris thyshe. In this inseet the wings expmol about two inehes and are transprerent, the veins and margins leing reddish-brown. 'The hear and tholax are olive-green: the upper part of the aloromen is crossed by a broad band of huff. while the lower part is rich reddish-hrown or maroon, and reddish-hrown beneath. The fan-like tail is black on the sides, with a yellowish-brown central tuft of hairs. The under side of the thorax and legs of the insect are light yellow. This insect is sometimes very common in .June and July, and may be seen on hot summer larys hovering over the flowers of the garden extracting their neetar. It lnoks not unlike a lumming-bird in miniature while on the wing. The blue blossoms of the pickerel weed, which grows so plentifully along the margins of most ponds and 
slow flowing rivers is a favorite flower with this moth. It looks as if suspented in the air while poised before the spike of blossoms, its wings moving so rapidly as to be sarcely visible. The larva, which feeds on the leaves of the snow-ball, is nearly two inches long, and is

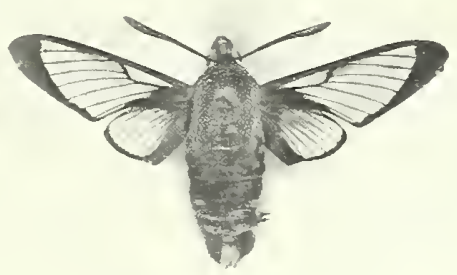

Hemaris thysue.

light green in color. When about to pupate it draws a few leaves and twigs about itself on the surface of the ground and makes a rude cocoon by spinning a few silken threads to hold them together. In this it passes the winter in the chrysalis state.

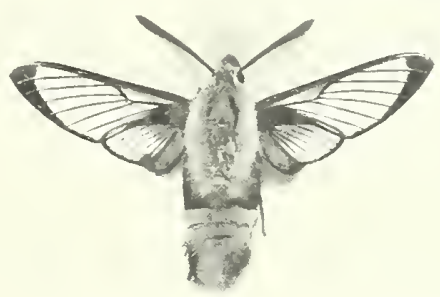

Hemaris diffinis.

Another species of clear-wing more common farther south than the preceding is Hemaris difinis, or the bumble-bee hawk moth. It is somewhat smaller than Hemuris thysbe, the veins and margins of the wings are darker brown, the abdomen beneath and legs are black, while the abdomen alone is crossed by a hroad band of rich recldishbrown. The top of the thorax is covered with light yellow hairs 
which give it while on the wing a bee-like look. The habits of the insect are much the same as the preceding. The larval feeds on the leaves of the bush honeysuckle and it makes a clumsy coconon of leaves and sticks on the ground under the bushes.

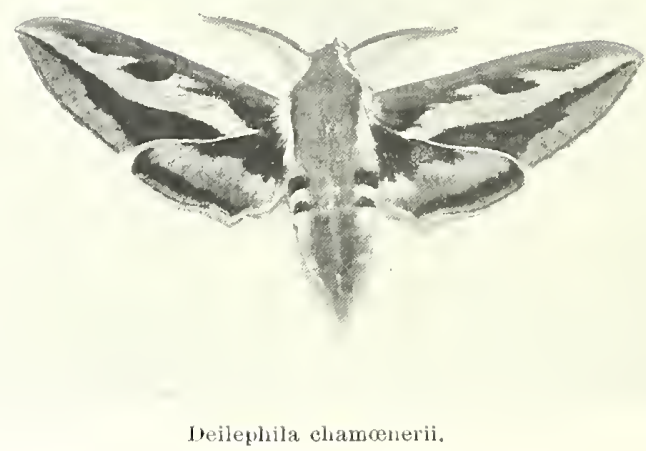

Deitephite chemenerii expands two and a half inches and is boldly and prettily marked. The body is olive-green above, with a white line along the sirles of the head and thorax, and white and black spots with a pinkish shade on the sirles of the abdomen. The fore wings are dark olive-green or greenish-brown, with an irregular buff stripe extending from the lower margin of the wing near the body to the tip; the outer margin is bordered by a band of gray. The lower wings are black, with a wide pink band extending across them with a white spot next the inner margin. This insect, although apparently not so common as the following species, is quite widely distributer. It may be seen early of a summer evening about the flowers of the evening primrose and the petunia, and is often so intent on its reprast as to allow itself to be closely approacherl. The larva is unknown to me, but is describer by Packard as " bronze-green, dull red beneath, with nine round cream-colored spots, pupilled with black, and having a dull red caudal hom." It feeds on the leaves of the willow herl.

Deitephita lineata expands from three and a half to four inches and is one of our prettiest sphinx moths, its close fitting scales and spindle-shaped body with the abdomen ending in a pointed tuft of hairs, giving it a trim and neat appearance. It is colored much 
like the preceding species except that there are several white lines following the veins and extending diagonally across the upper wings. There are also white lines on the thorax. and the abdomen has a decided rosy tint besides the black and white markings. This insect is found from the Atlantic to the Pacifie coast, and extends well up into Canada and also into the southern parts of the comntry, as far down as the Gulf of Mexico. It is very ahundant in some parts of

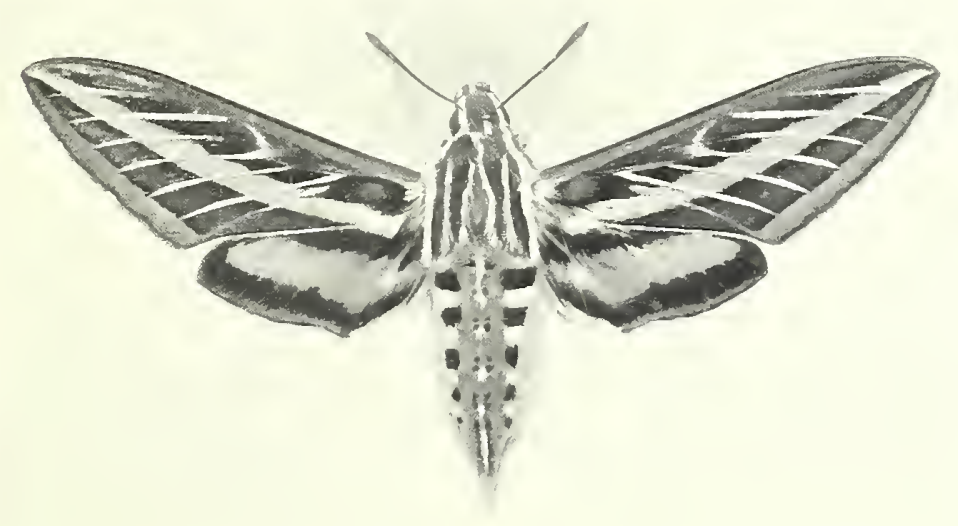

veilephila lineata.

the country, and I have taken it in numbers in Saeramento, Cal., where early on a dnne evening. even hefore sunset, it might be seen fying in wide cireles over the fields of wihl flowers or proised before the spikes of blossoms daintily extrating their sweets. The latra is yellowish-green in color, and feeds on the leaves of the apple, phum and enrmat. It is said to be donble-brooded in the sonthern part of the country.

On the grape and Virginia creeper may often be seen during July and August the larva of Emry myron. This caterpillar is about two inches long when fully grown, green in eolor with a whitish stripe edged with dark green along each side extending from the hear to the caudal horn, and oblique matkings of yellow shaded behind with dark green also on the sides. There is, too, a row of pink spots down the back. Oceasimally a specimen may be found of a strong pink, brownish-pink or even reddish color. In sueh an 
insect the stripes and lines are ustally pale, pink instead of yellow or white. The two forwarl segments next the head are small, and those farther back much swollen, so that the hear and first segments may be butly retrated and almost concealed beneath the folds of

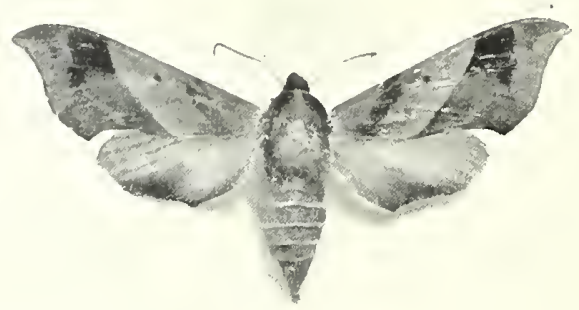

Everyx myron.

the large fleshy parts, giving the eaterpillar a hmmped appearance and suggesting the common name of hog caterpillar. These larve are often attacked by parasitie insects, whose grubs feed on the flesh and fat of the eaterpillars which later may be found $\mathrm{n}$ an an enfeebled eon-

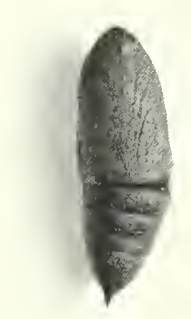

Pupal of weryx myron.

dition crawling about with the eocoons of their destroyers clinging to their sides and back. The larva makes a poorly construetod coemon on the surface of the ground, comprosed of leaves held together with a few silken threarls. The elnysalis is yellowish-gray and is 
sprinkled with black dots. The moth expands about two and a half inches. The body and forward wings are olive-green, the wings

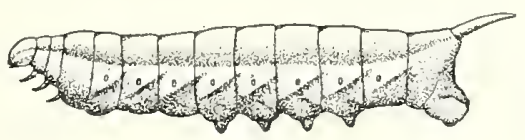

Larva of Everyx myron.

being crossed by a vaguely defined band of flesh color, while the lower wings are brick-red in color with a softly shaded patch of olivegreen at the lower angle. This insect is widely distributed over this country.

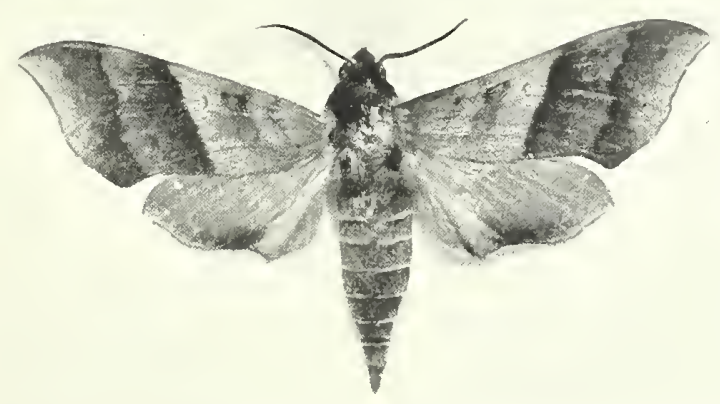

Everyx chorilus.

Another insect not rare in the eastern half of the comntry is Everyx cherilus. The predominating color is reddish-brown, but the fore wings are crossed by bands of yellowish-brown and pinkish-gray, while the lower wings are brick-red with a dark brown shade along the lower margins. This insect may be taken about lilacs, and may occasionally be seen flying around the electric lights in our towns.

Philampelus pandorus and the following closely allied species are grand inscets, easily holding first place among our native sphinxes. The expanse of wing is from four and a half to five inches, and magnificent is the only word that seems to do justice to the size and coloring of these fine moths. The present species is olive-green and gray with dark velvety patches of greenish-brown on the upper, and 
back on the lower wings. A rosy tint is diffused over the greens, grays, and olives which are softly blended and shaded into one another in a most charming mamer.

$A$ designer of gool taste and refinement might evolve from this moth's velvet coat a dress of modest loveliness for a larly which would malie her the envy of her fair sisters. The sight of such an insect in its perfeet beanty having reeently spreal its wings from the narrow confines of its hark, hrown chrysalis, is apt to set one wondering why

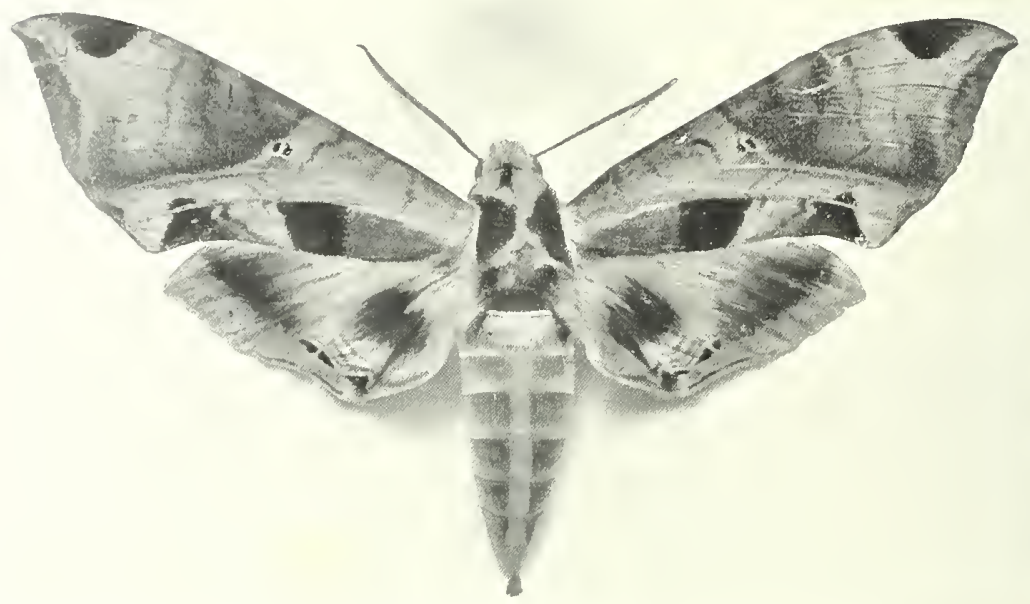

Philampelus pandorus.

our costume maker's do not go more to Nature's art school for their suggestions.

The habits of this insect are mueh the same as those of other long-tongned species of splinxes, whieh in the dusk of morning and evening extract the nectar from the fresh opened flowers. It is sometines to be seen flying in circles ahout the electric lights in cities, but I have never known it to be attracted by the light of a common kerosene lamp. This is true of most of the sphinx moths. It takes the powerful rays of the eleetrie light to dazzle and bewilder them.

The larva of this moth is large and fleshy, and like the preceding it can, by contracting the first three segments, almost completely hide 
them beneath the fleshy folds of the much swollen following segment, thus making the insect look very blunt and humped at the anterior end. It is smooth, without hairs or tubercles except an eye-like spot on the top of the posterior end of the body. The color of the larva is usually light green, although specimens are to be found of a flesh or brownish-pink color. Along the side runs a row of broad oval spots, yellowish in color, obliquely placed on the segments. The forward part of the body is covered with a fine stipple of black dots. The young of this larva is interesting from the fact that it is usually light pink, and has a curled spine on the posterior end of its body, which after two or three moults disappears, leaving only the cye-like tubercle before mentioned.

This caterpillar feeds on the leaves of the grape and Virginia creeper, and on account of its large size, often three or four inches long, and as thick as one's thumb, it consumes large quantities of the leaves, even eating the midrib down to the stem. It is rarely, however, found sufficiently abundant to do any great damage.

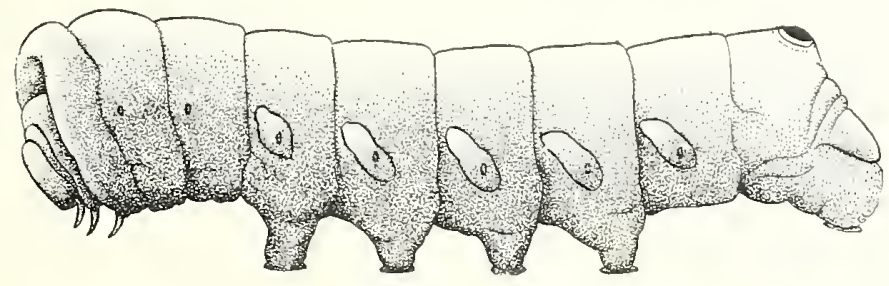

Lidra of Philamperus paudorus.

In Philampelus achemon the larva very closely resenibles that of the preceding species both in its habits and its shape and coloring, except that the spots arranged along the sides are much longer and narrower, are scalloped on their edges, and a long Jellowish stripe extends above the spots the entire length of the caterpillar. This species also feeds on the grape and Virginia creeper, and when fully grown in the latter part of August or early in September it, like the larva of the preceding species, burrows into the earth a few inches. whele it changes to a pupa without making a cocoon of any lind, simply excavating a smooth cavity or cell in the soil. The perfect insect comes forth the next July. This moth is somewhat smaller than Plilampelus pandorus, but is very beautiful, the forward wings and the borly of a light pinkish-brown with intensely dark brown patches 
arranged as shown in the figure. The lower wings are rose eolor, being light buff next the body, and bordered externally with light brown and dark brown spots and shadings. This insect is probably less abindant than Phitampelus pandorus. Both are widely distrib-

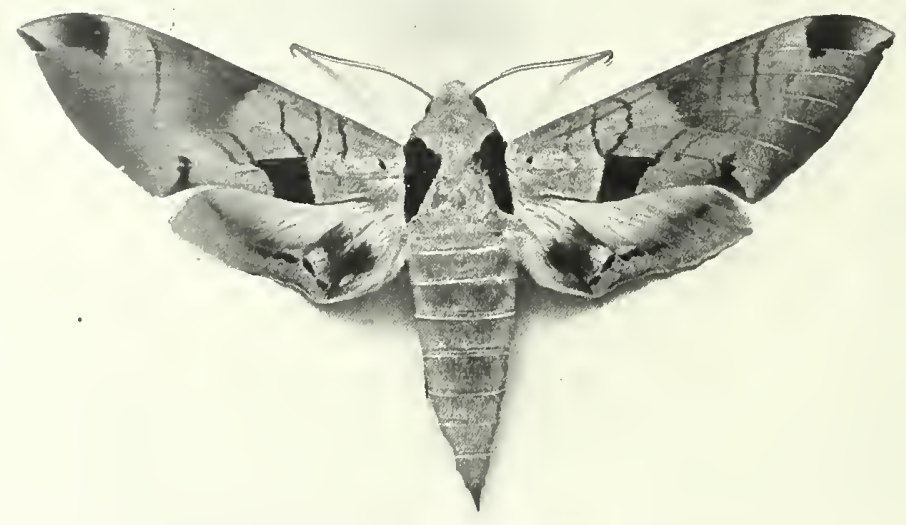

Philampelus achemon.

uterl, being found from the Atlantic to the Paeifie eoasts of our country, and from Canada well into the Southern States, while allied speeies oceur in Mexico.

The tomato-worm moth, Macrosila quinepemaculatus, is one of our largest sphinx moths, and althongh ashen gray with a few dark brown and black markings, is still a fine inseet. 'The length of the tongue of this inscet is very remarkable, and on this account it is able to extract the nectar from our largest and deepest flowers. It is interesting early on a quiet summer evening to stand beside a bunch of phlox or a bed of petunias and watch this moth hovering over the flowers. It is strong and rapid on the wing, and on aecount of its size and the directness of its flight looks quite bird-likc.

The legs of the moth are armed with sharp spines, so do not try the uipleasant experienee of taking one of these muscular insects by hame. Even if through your love for collecting you manage to hold it, the specimen is liable to be ruined in the struggle to escape.

The larva of this insect feeds on the leaves and even the young 
fruits of the tomato. It will also eat potato and tobaceo leaves, and in some parts of the country does great injury to the tobaceo crop

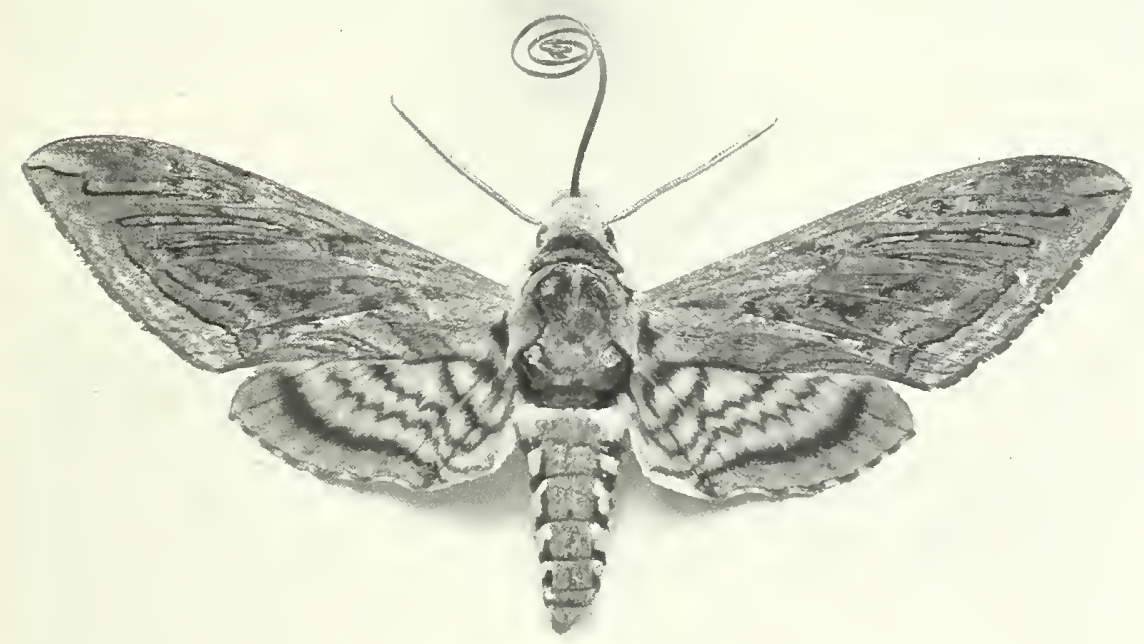

Macrosilat qunquemaculatus.

unless men are constantly engaged in "picking worms" from the plants.

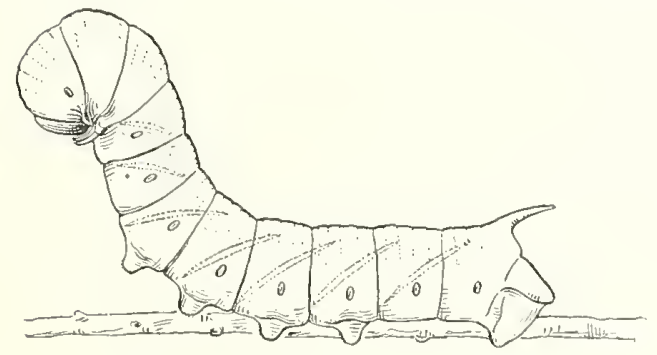

Larva of Macrosila quiuquemaculatis.

The larve are usually green with a curved caudal spine. Specimens are occasionally found of a dark brown or black color.

One can frequently locate the larva on its food plant by shaking 
the stems and listening for the snapping noise made by the jaws of the lar'va as it swings its head from side to side in a menacing manner. It is quite harmless. however. The pupa is interesting from its tongue ease, whieh looks not unlike the handle of a jug. It is frequently found while spading or ploughing the garden. The pupa passes the winter several inches under ground, and works its way to the surface in spring when it is ahout to break the pupa case and emerge a perfect fly. (See figure on page 140.)

This insect is widely distributed over the whole of the United States and Canada.

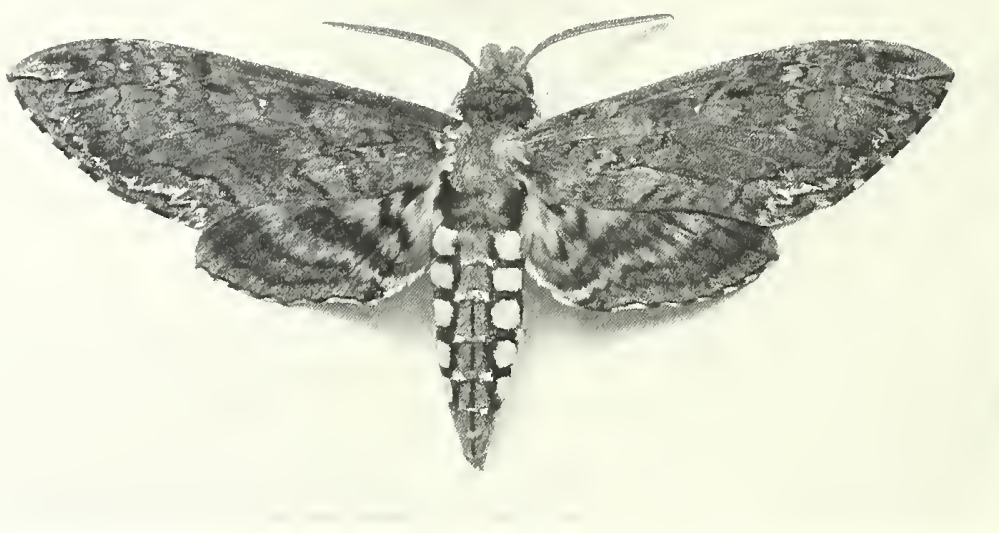

Mucrosila caroluma.

The Carolina splhinx, Macrosila carolina, very closely resembles the foregoing in all three stages of its existence, and also feeds on the same plants. It is, lowwerer, a somewhat smaller inseet, and the moth is more brownish in color with less graty, while the black markings on the lower wings sun more together and are not zigzag as in quinquemuculatus. The larva is green, stippled with white dots, with seven oblicque whitish stripes, and a light longitudinal line extending along each side. The stout eaudal horn is usually bluish.

They are frequently, among the eountry folks, eonsidered venomous, the cautal horn probably giving rise to the idea that they ean sting.

A large eaterpillar, which feeds on the leaves of the elm and is 
interesting from its protective mimiery, is the larva of Ceratomin quadricornis. This larva is green, of the exact tint of the underside of the elm leaf, and along its sirles are a number of oblique light

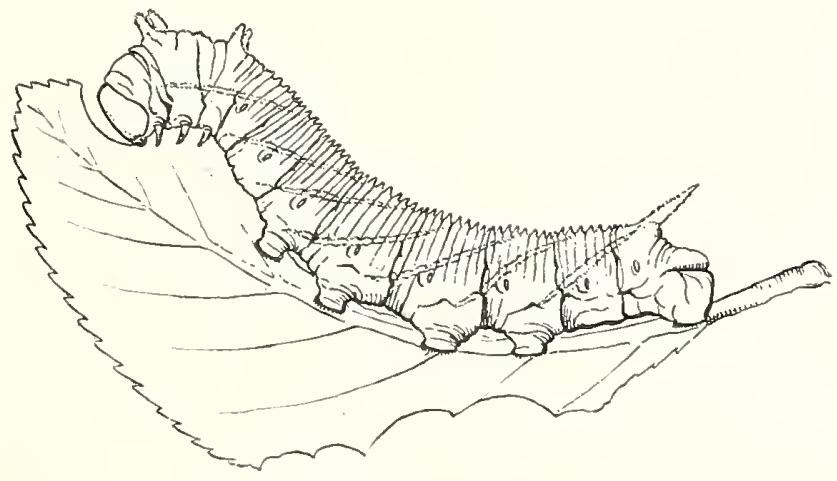

Larva of Ceratomia quadricornis.

lines. A line down its back is serrated, and on the forward part of the body are four soft green homs, also serrated. While this insect

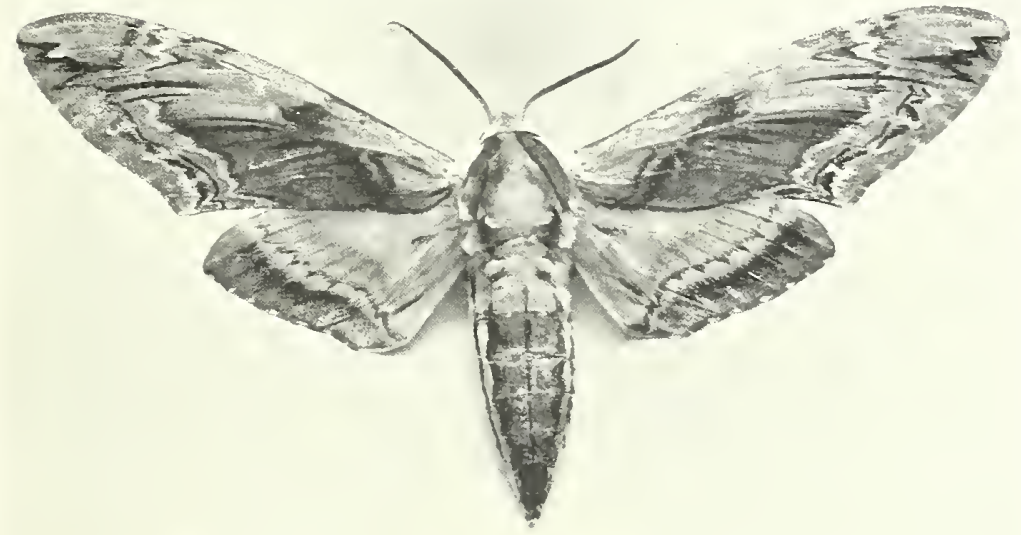

Ceratomia quadricornis.

is at rest clinging to the midril, on the underside of the elm leaf it is a difficult ereature to see, and one may gaze directly on it and still think he is looking at a slightly curled leaf. The light line down 
the back answers to the midrib of the leaf, the ollinge stripes on the sides look like the main veins, and the green homs closely resemble the notched tip of the leaf. One may readily locate the creature by observing the pellets of excrement on the ground under the trees, hut even when he is known to be on a certain branch he is not easily seen. The caterpillars may sometimes be seen on the trunks of trees as they are making their way down to the ground to mulergo their transformations in the soil. The moth is four inches or more in expanse and is light brown in color, with lines and markings of dark brown, black ant gray.

The aterpillar descends into the ground during Augnst or September and emerges a moth the next July, when it crawls up the trmuk of an elm tree, waiting until evening when its wings are sufficiently strong to enable it to take flight.

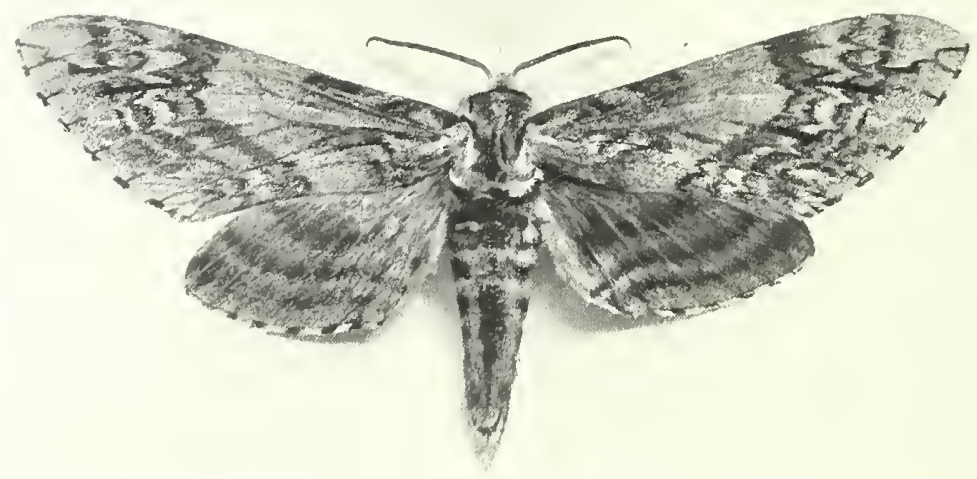

Jaremma undulosa.

Theremma undulose is a goor-sized moth of a brownish-gray color, with a few light gray and dark brown or hlate markings distributerl as shown in the figure. It is not a rare moth and will sometimes be attrarted by the collector's lamp. It is rarely taken about flowers as it does not seem to be as partial to sweets as many of the sphinxes.

I small moth somewhat resembling the preceding in its markings is Inollue hyldens. The upper wings are light reddish-brown and gray with many black and brown lines. The lower wings are sooty-brown 
and white. The thorax is reddish-brown with white stripes on the sides, and the aldomen has several white hars on the sides with two rows of white clots down the back. This insect is common in the southem states and I have taken a few in Massachusetts and Ohio.

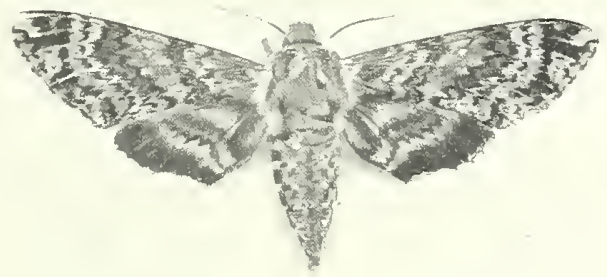

Tolba lylaus.

A very common splinx moth with a wide geographical range extending over the larger part of this country and Canada is Spphin. gordius. This insect is dark sooty gray and light gray or white with several black hars on the sides of its body, and a few pen-like marts-

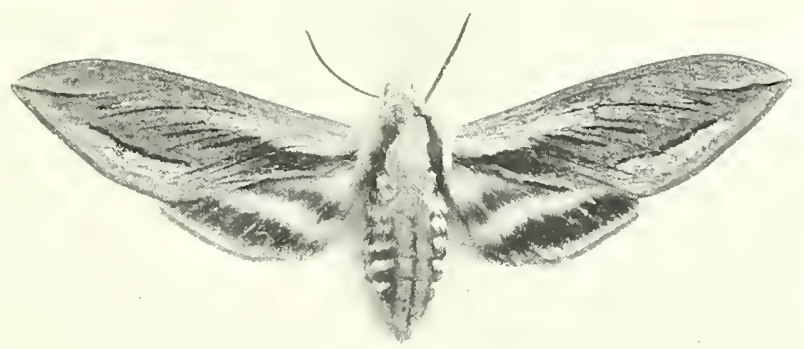

Sphinx gordius.

ings also in black on the wings. It is very partial to lilac blossoms, and when the clnsters of flowers are fully expanded it may sometimes be seen at dusk on a warm quiet evening in some numbers. So intent are these moths on their feast of honey that one may approach 
quite near them and watel them guide their long flexible tongues into the tiny flowers. The motion of their wings is so raphid that they make a slight whining noise and in the half-light are almost invisible. The larva is green with light oblique stripes on the sides, and it feeds on the leaves of the apple though it is rarely suffieiently plentiful to do much damage.

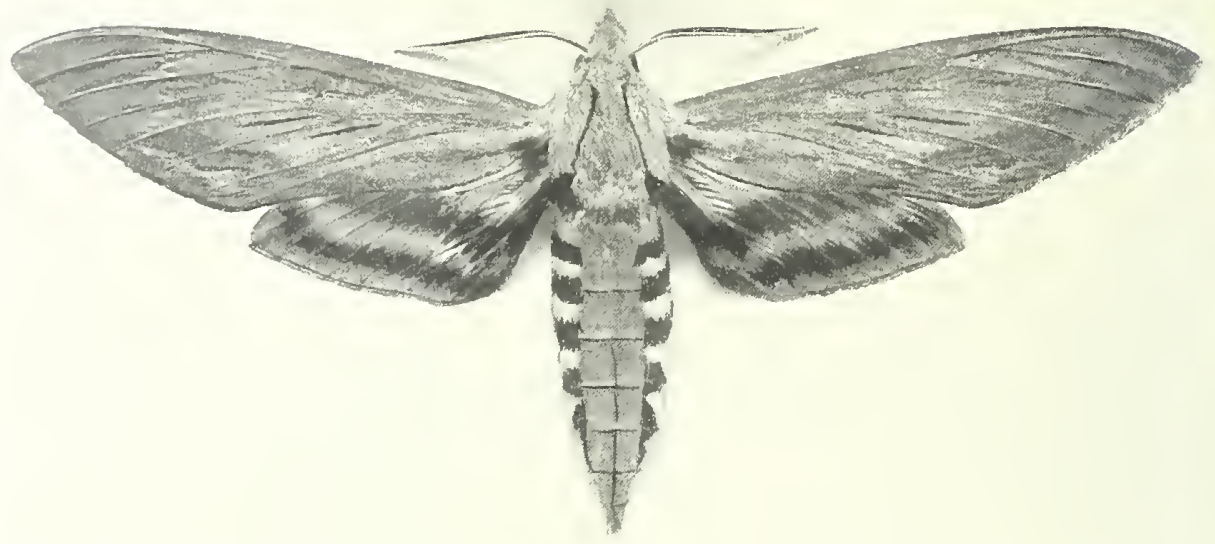

Sphinx chersis.

On the ash ant lilac, in Sertember, may be found a plump, handsome green eaterpillar, whitish on the back and laving seven oblique light yellow stripes on its sides edged above with dank green. This in the larva of Sphiner wersis. The moth is ashen gray in tolor with several black and white bands on the sides of its body, two heavy black lines on its lower wings and a few pentlike markings in black on its forward wings. It is a large powerful moth and has a strong, lalid flight.

Spthin drupifurum is also a good-sized moth. being four inches or over in expanse of wing. The general color is clark sooty brown. The onter margin of all four wings is light brown while a large area along the upper margin of the upper wings and a band across the lower wings is gray. IBlack and white bands alternate on the sides uf the bonly. The larva foerls on the leaves of the phum and hackberry. It is light green with white stripes edged above with purple. 
Spline kalmie expands about four inches, and is buff and rust-red in color, with reddish-brown makings streaking the npper wings. It is not a rare insect, and may be taken early in the season about

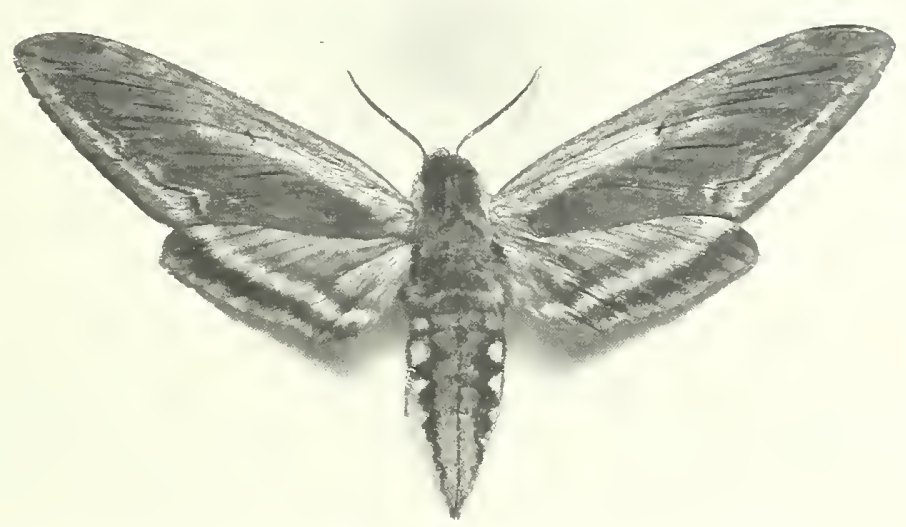

sphinx drupiferarum.

the lilac blossoms. The lar'va is pale green with oblique lands of yellow on the sides, edged above with black and blue. It feeds on the leaves of the litae and laurel.

A plainly tinted but gracefully shaped insect is Chtoerocempotersa. In this moth the body is long and tapering. ending in a tuft of hairs. The upper wings are long, narow and pointed, while the lower pair is small in proportion. Its body is tam with a yellowish stripe on either side, and the thorax and head is brown witl a light gray hand also on the side. The unper wings are light brown crossed diagonally with numerons brown lines. The lower wings are black margines with brown, with a row of light yellow spots extending above the brown margin. This insect is more plentiful in the soutleern parts of the country, and is rather common in Washington. D. C., where about the electric lights they may frequently be taken in July and August.

One of our earliest splinx moths to be seen in the spring is Thyreus abbotii. The lilac blossoms are very attractive to this species, and on a May evening it may be seen hovering about the elusters of flowers. It is not very shy, and may be easily taken with the net. The general color of the moth is dark purplish-brown. The fore wings are crossed by numerous black lines, while a broad band of black and 
dark hrown extends along the outer margin of the lower wings, the rest of the wing heing yellow. The body is bluish-gray and brown, with lines and bands of black. From the sides of the body spring tufts of

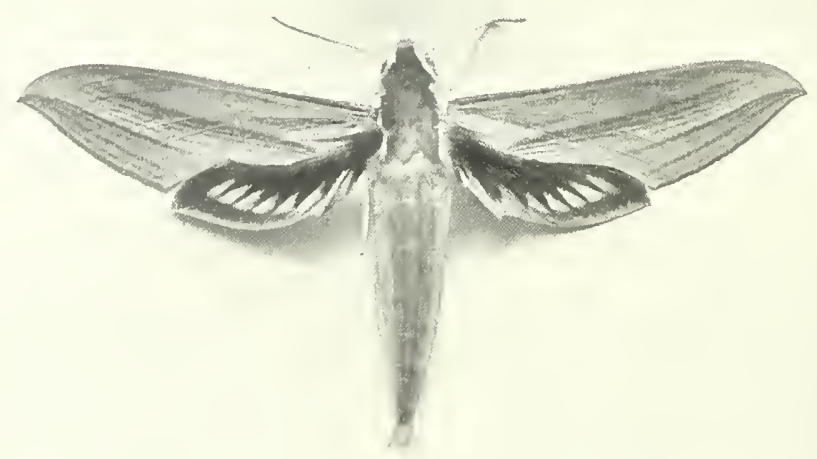

Chloerocampa texsa.

hairs, and three spreading plumes of long yellowish-brown hairs adorn the end of the abdomen. These latter the insect ean spread or contract

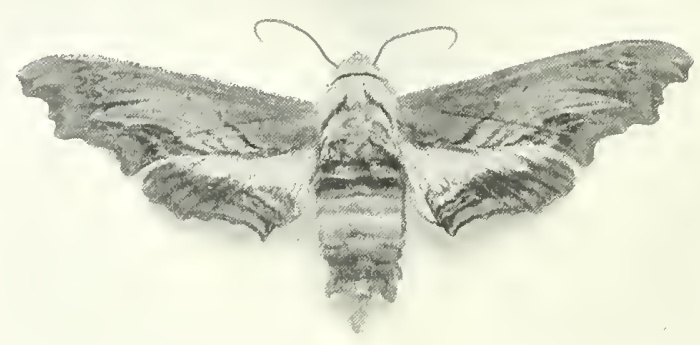

Ihyreus abboti.

at pleasure, and are no doubt of value in guiding its rapid flight. 'The caterillar of this moth feeds on the leaves of the Virginia ereeper, and in its markings elosely resembles a seetion of the stem of the vine. 
It is grayish or greenish brown in color, crossed by numerous darker brown markings. The under side is pink. At the posterior end is an eye-like spot or tubercle, making the insect look, as one observer worded it, "as if the worm had a head at eaeh end." When handled the caterpillar twists its body vigorously from side to side, making at the same time a squeaking noise. The winter is passed in the ehrysalis state, a few inches beneath the surface of the ground.

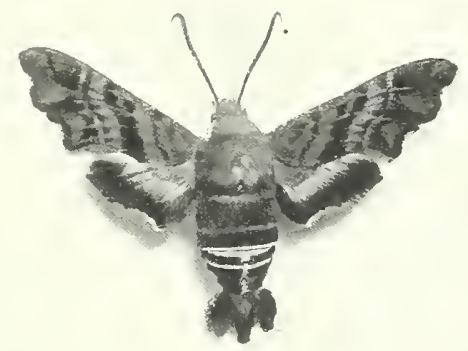

Auphion nessus.

A little jewel among the sphinx moths is Amphion nessus. It expands a little over two inches, and the wings are very much sealloped. The ground-eolor of the fore wings and thorax is purplish-brown, the wings being erossed by dark velvety brown markings and faint yellowish lines, with a spot of reddish-brown near the tip of the wing. 'The lower wings are margined with a broad band of brown edged with yellow, the rest of the wing being reddishthrown. The abdomen is dark reddish-brown, lighter on the sides, and is erossed ly two eonsplicuous bright yellow bands. The end of the abdomen bears three tufts of long dark brown hairs which may be spreal or contracted at the pleasure of the insect. The white lilae and syringa are favorite flowers. Its flight is not so rapid as that of other members of the family, and it may be easily taken, even by hand.

I have never found this insect aloundant but have had numerous speeimens sent me from Ontario, Canada, and also from Virginia.

The genus Smerinthus eontains some large and very handsome moths. Unlike the species of sphinx moths already deseribed. in this genus the tongue is very short, almost wanting in fact, and can be of little use to the insect. The fore wings are scalloped on their outer 
erkes, and the moths are sluggish in their hahits, flying only by night, and then in a vague and uneertain manner, eontrasting greatly in this respect with the strong, direct flight of most of the spreeies of the

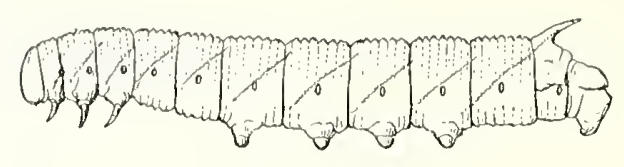

Larva of Smerinthus.

family. The larve are monally green in enlor, and their skin is rough and gramular, giving it a hatd sandproer-like feeling. The thansformations are passed in the grount.

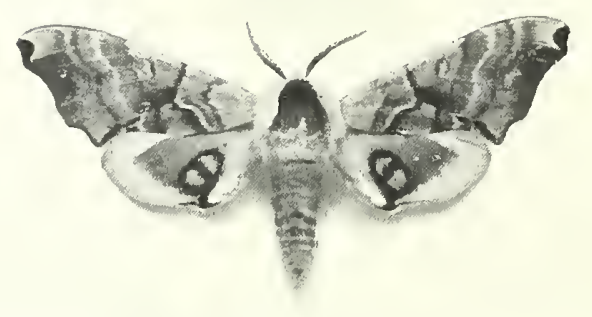

Smeriuthus geminatus.

Our beautiful little Stmerinthus geminutus is not a rare insect, anrl may often be taken with the colleetor's limp in July. The uper wings are gray with a faint rosy cast, and are crossed loy lines and hands of olive and lich velvety brown. 'The thom is also gray, with a large triangular patch of diuk brown oecupying the middle. The lower wings are rich earmine margined with gray, with a large black spot located near the inner angle of the wing, in which are two bhish1mile spots. The larva of this insect lives on the leaves of the apple, fhum, willow and asth, and is green in color with yellow stripes on the sides. Its skin is covered with fine white granules, and it has a triangular head. The pupe of this species may often be found in eomretion with that of the following, in the soil at the roots of ash and willow trees. 
Smerinthus excocatus is not so exquisitely colored as the preceding species, but is still, when freshly hatched from the pupa, a very pretty insect. Its general color is fawn, with lines and bands of brown and

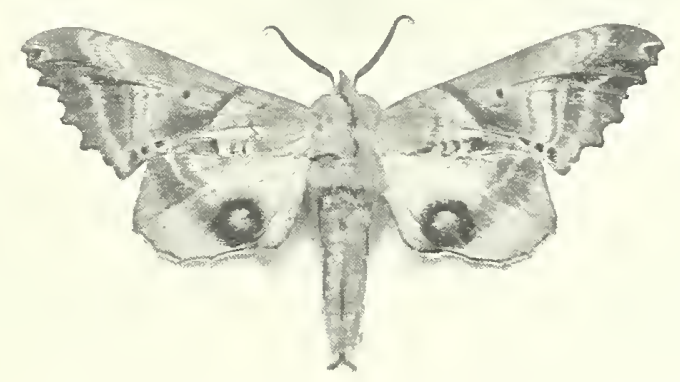

Smerinthus excreatus (male).

tan. In the middle of the lower wings is a rose-colored patch, and near the inner angle is a large black spot with a dim blue centre. The eggs of this moth are large in proportion to its size, are oval in shape.

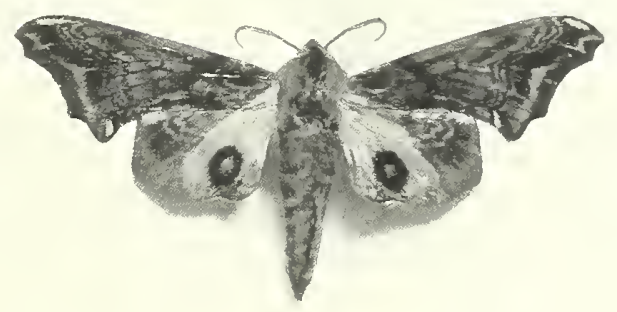

Smerinthus myops.

transparent green in color, and look not unlike malaga grapes in miniature. The larva is green with yellow stripes on the sides. The caudal horn is blue. This eaterpillar feeds on the leaves of apple, 
wild cherry, eln, ash, ete., and may he foumd near the tips of the branches devouring the young and tender foliage. Young trees and bushess seem to be more subject to the attacks of the larve of these moth than older and larger trees. This insect is found from Canada to Virginia thronghout the Atlantic States.

A clark brown insect somewhat resembling the foregoing is Smerinthes myops. The fore wings and loody are dark purplish-brown with light purple lines and markings, and the lower wings lave the eye-like spot of the preeerling species, but are much dirker generally. In

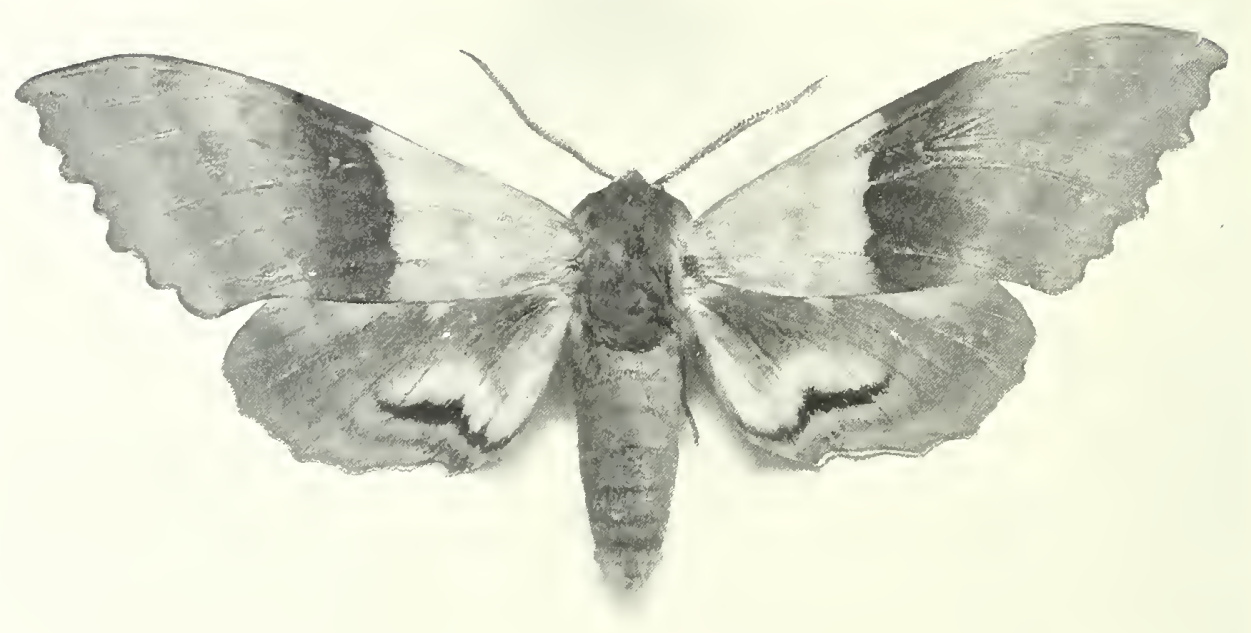

Triptogon modesta.

habits the two speeies elosely resemble each other. While at rest langing from the stem of a plant, the sealloped outline of the wings of these insects, together with their hrown or tan colors and the peculiar bent attitude in which the body is held, give them a resemblance to brown and withered leaves. So eomplete is their mimiery that one may be ohliged to touch the inseet before being sure of its identity.

A fine large, but rather rare, insect having a wide range over the northern half of the country is Smerinthes or Triptogon modesta. This moth expands, in a fine specimen, from five and a half to six inches, and its colors are soft and pleasing. The outer two-thirds of 
its fore wings and the outer margin of the lower wings are olive. The inner third of the upper wings and the inner margin of the lower wings are light gray. The middle of the lower wings is dull carmine. while near the imer angle is a bluish-gray patch having a curved black line over it. The body is greenish-olive. This fine moth is rarely captured by the collector, but it may be reared from its larva, which is not uncommon, and is to be found feeding on the leaves of the poplar and cottonwood in September. It is a large green caterpillar three or four inches long, and on account of the rough, white gramulations with which its boly is covered, it has the appearance of being sprinkled with dew or frosted. A closely allied insect or a variety of this same species is rather abundant in the western states and on the Pacific coast of this country. 






\section{2}






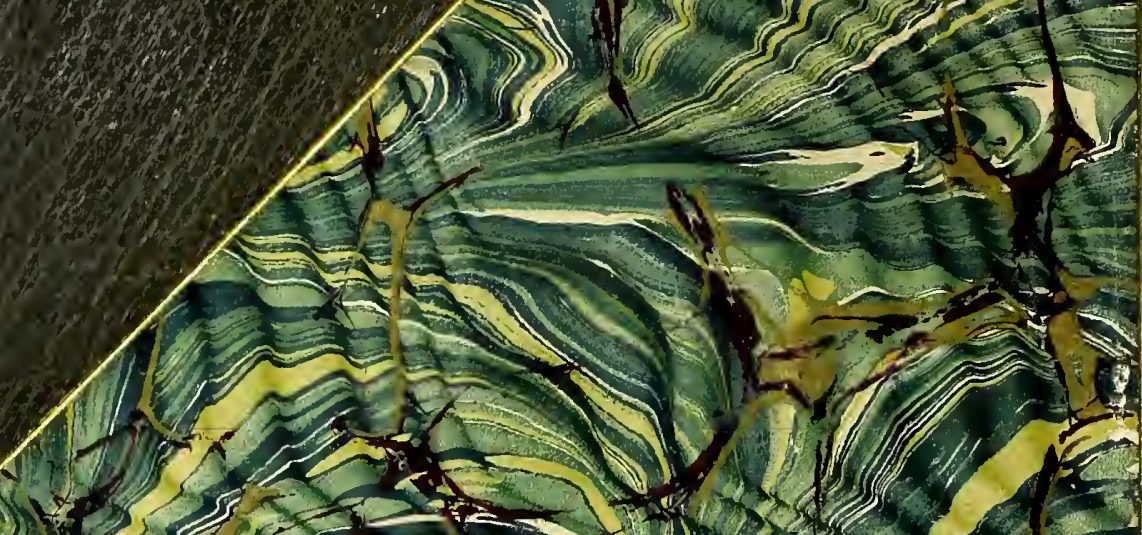
10. 5 . 7 ,

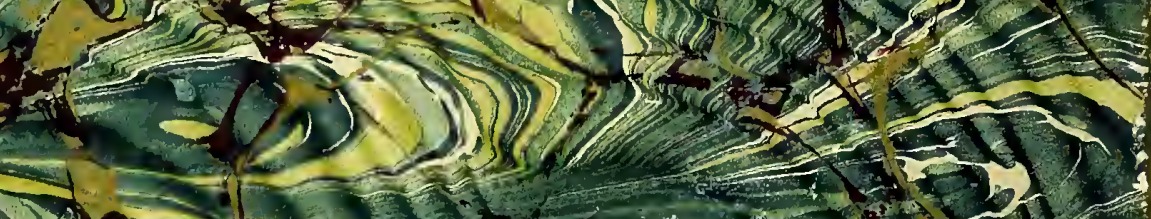
) $\int_{0}^{2}$ ST $15(3) 3,5$

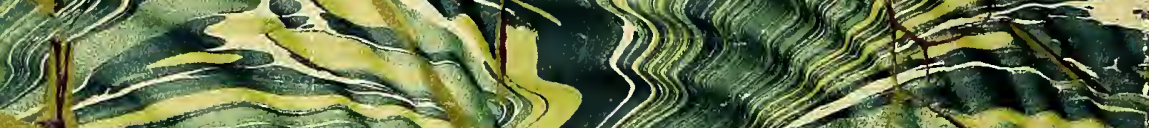
21

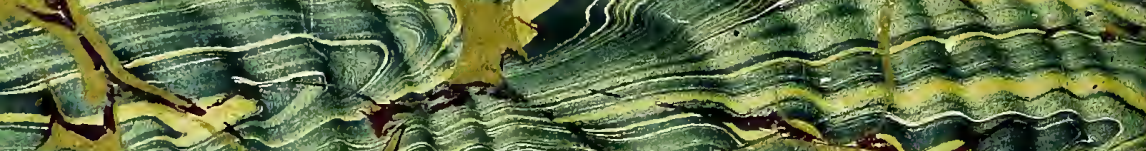

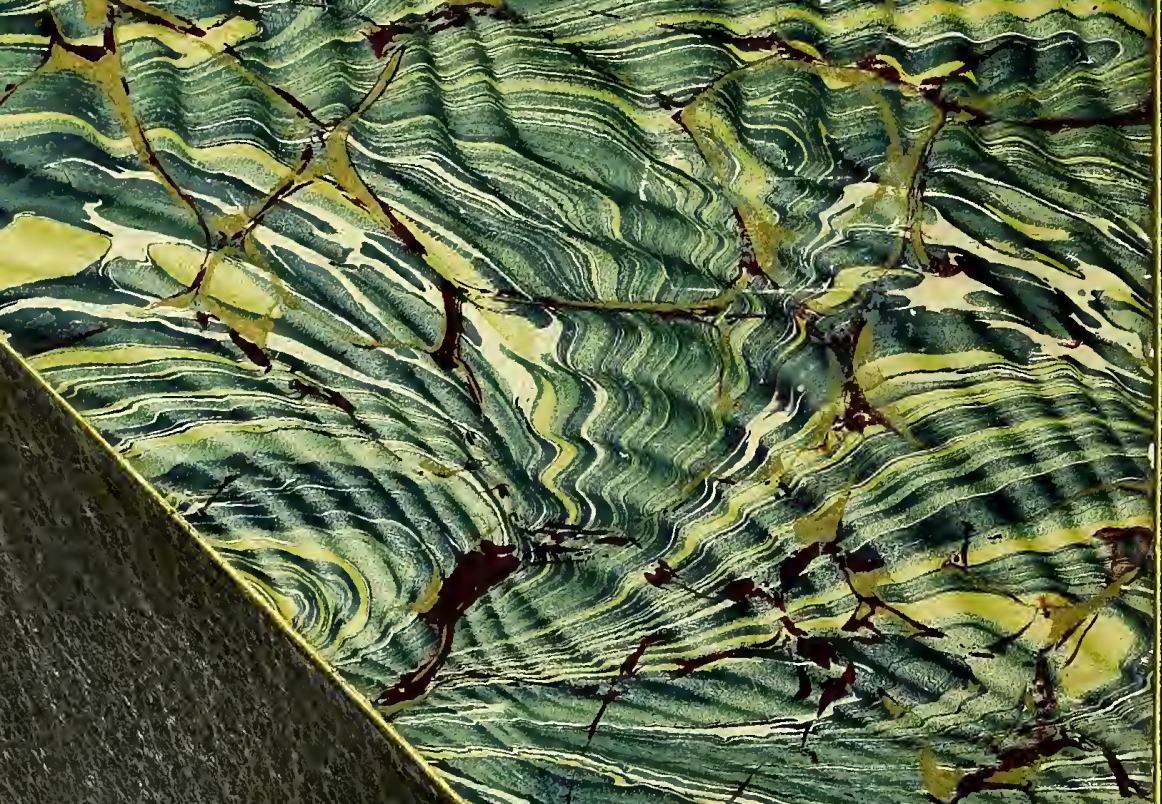

